\title{
International Union of Basic and Clinical Pharmacology. LXXXI. Nomenclature and Classification of Adenosine Receptors-An Update
}

Bertil B. Fredholm, Adriaan P. IJzerman, Kenneth A. Jacobson, Joel Linden, and Christa E. Müller

Department of Physiology and Pharmacology, Karolinska Institutet, Stockholm, Sweden (B.B.F.); Division of Medicinal Chemistry, Leiden/Amsterdam Center for Drug Research, Leiden, the Netherlands (A.P.IJ.); Molecular Recognition Section, Laboratory of Bio-organic Chemistry, National Institute of Diabetes and Digestive and Kidney Diseases, National Institutes of Health, Bethesda, Maryland (K.A.J.); Division of Inflammation Biology, La Jolla Institute for Allergy and Immunology, La Jolla, California (J.L.); and PharmaCenter Bonn, University of Bonn, Pharmaceutical Institute, Pharmaceutical Chemistry I, Bonn, Germany (C.E.M.)

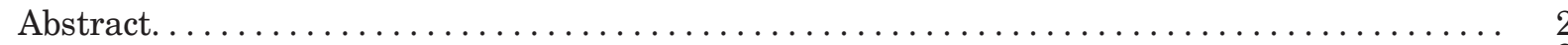

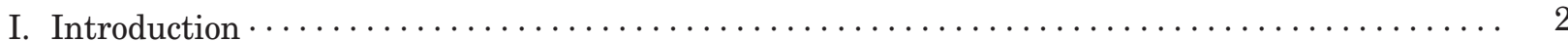

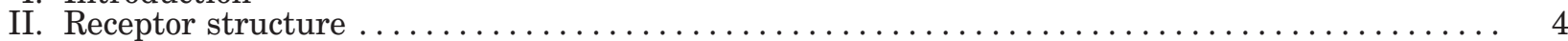

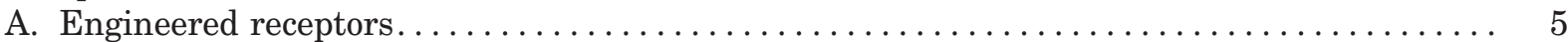

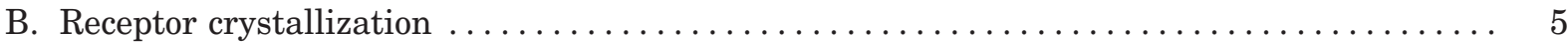

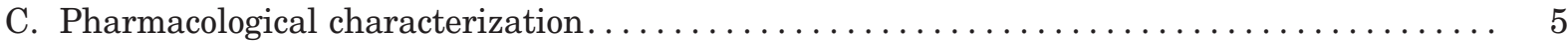

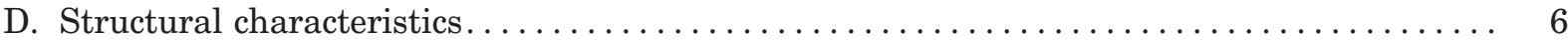

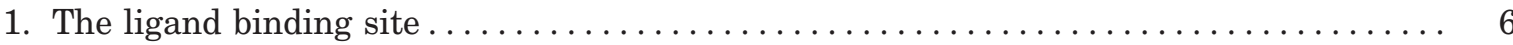

2. "Toggle switch" and "ionic lock" $\ldots \ldots \ldots \ldots \ldots \ldots \ldots \ldots \ldots \ldots \ldots \ldots \ldots \ldots \ldots \ldots$

E. Receptor structure and receptor homology modeling $\ldots \ldots \ldots \ldots \ldots \ldots \ldots \ldots \ldots \ldots \ldots$

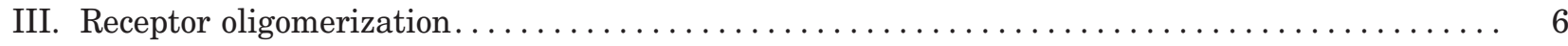

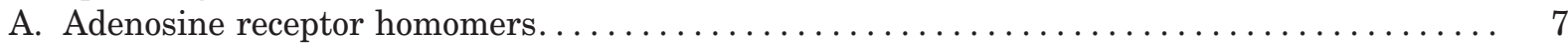

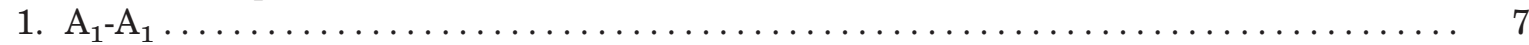

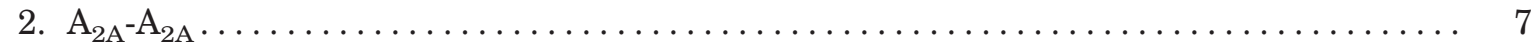

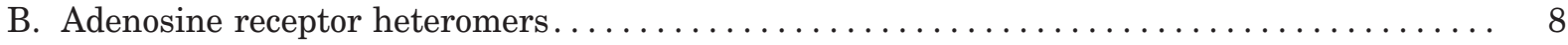

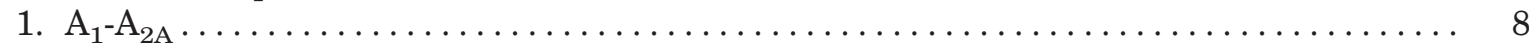

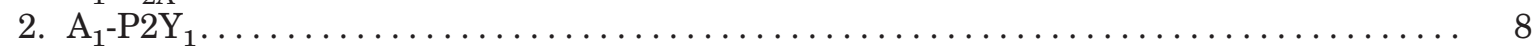

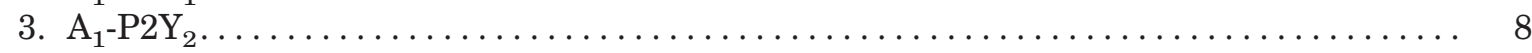

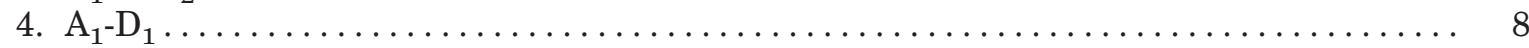

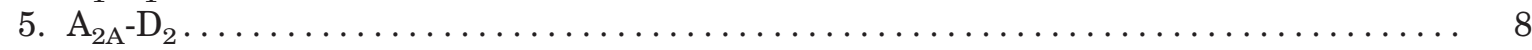

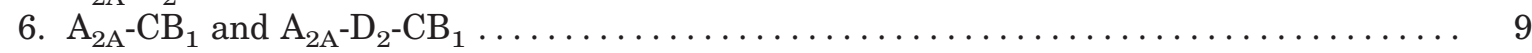

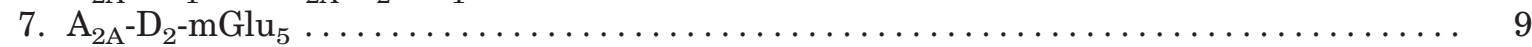

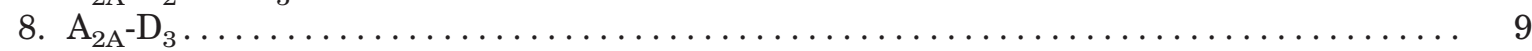

C. Adenosine receptor heteromerization with other proteins $\ldots \ldots \ldots \ldots \ldots \ldots \ldots \ldots \ldots \ldots 9$

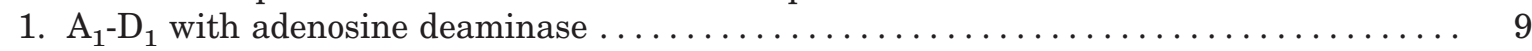

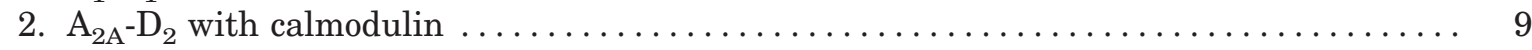

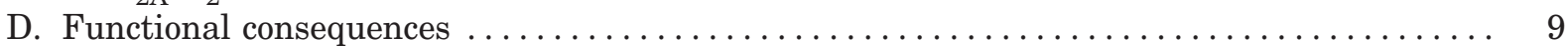

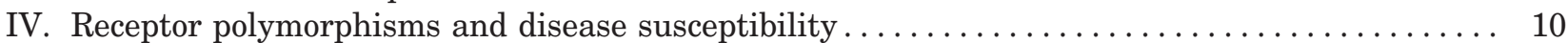

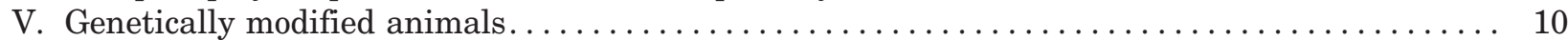

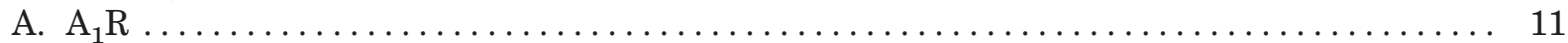

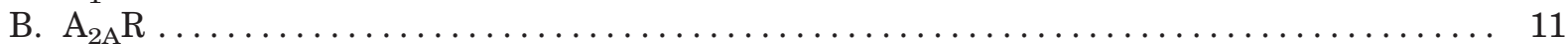

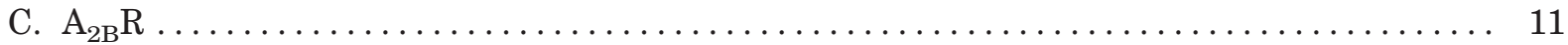

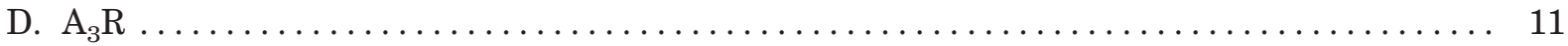

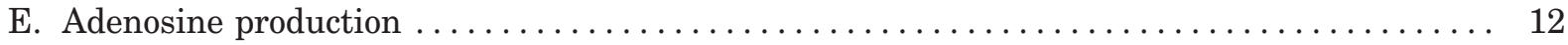

VI. Receptor classification: new drugs $\ldots \ldots \ldots \ldots \ldots \ldots \ldots \ldots \ldots \ldots \ldots \ldots \ldots \ldots \ldots \ldots \ldots \ldots, 12$

VII. Allosterism ............................................ 19

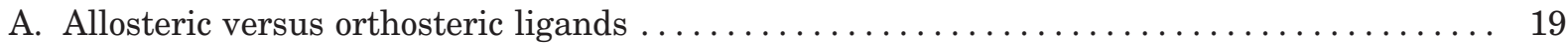

Address correspondence to: Bertil Fredholm, Karolinska Institutet, Nanna Svartz 2, Stockholm, Sweden, S-171 77. E-mail: bertil.fredholm@ki.se.

This article is available online at http://pharmrev.aspetjournals.org.

doi:10.1124/pr.110.003285. 


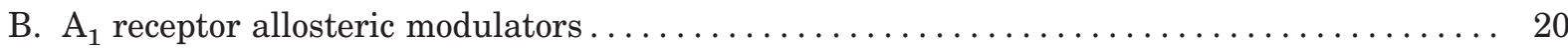

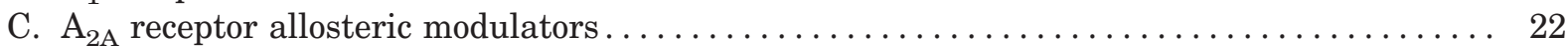

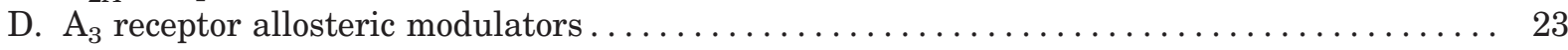

E. Evidence for mode of binding of adenosine receptor allosteric modulators $\ldots \ldots \ldots \ldots \ldots 25$

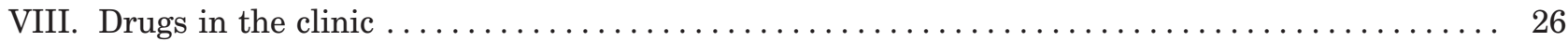

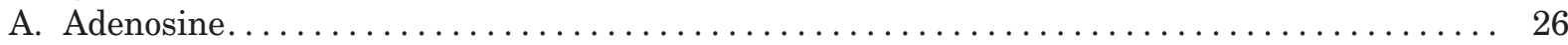

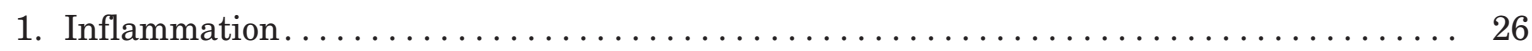

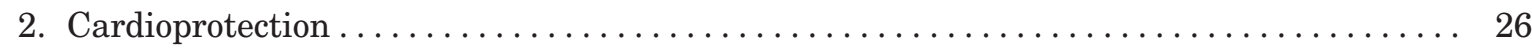

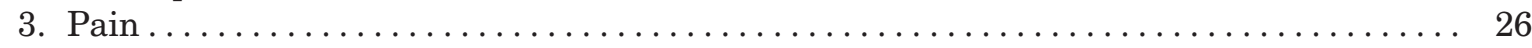

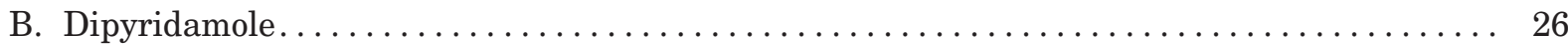

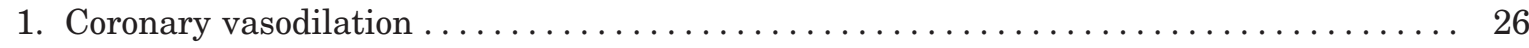

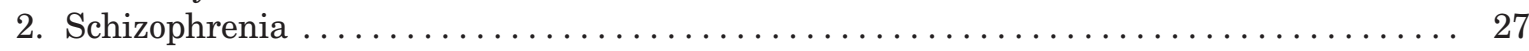

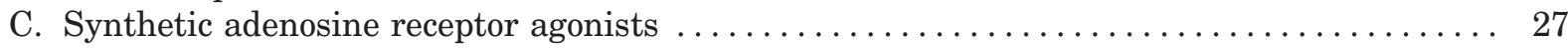

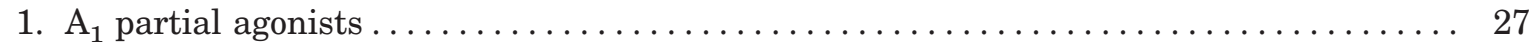

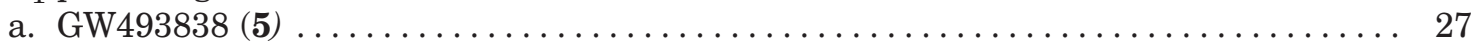

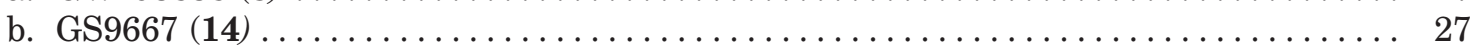

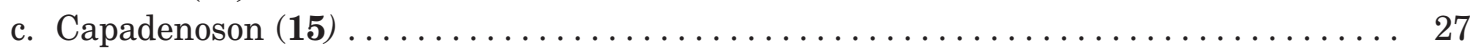

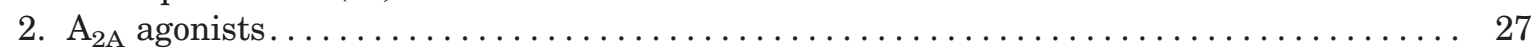

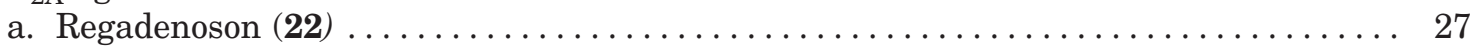

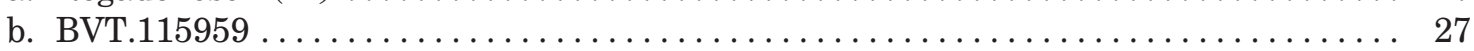

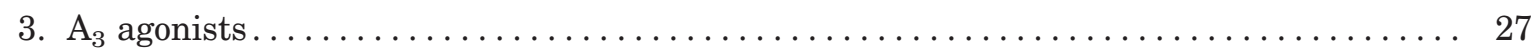

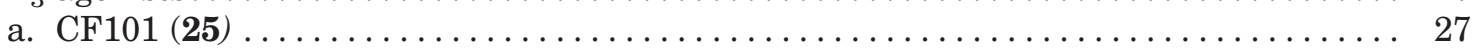

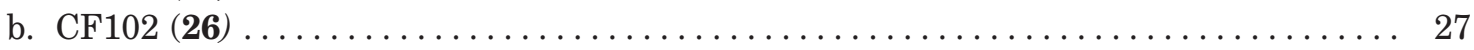

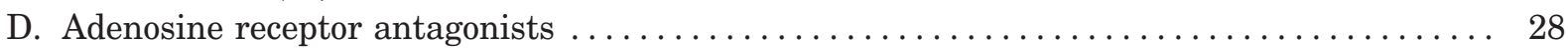

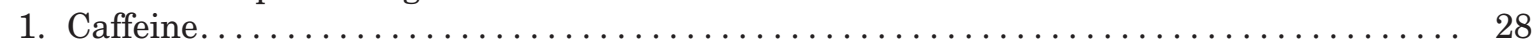

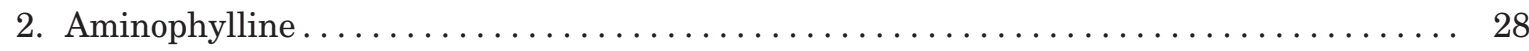

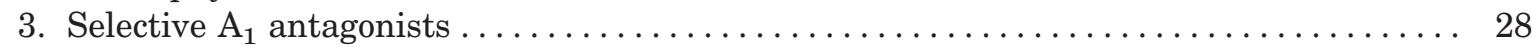

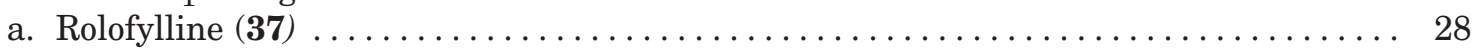

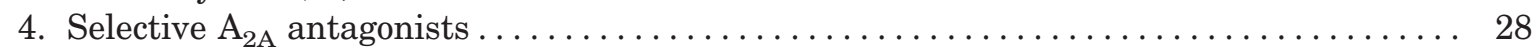

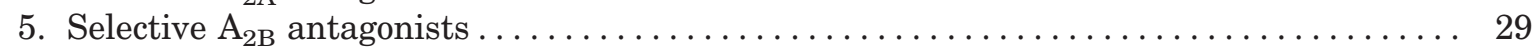

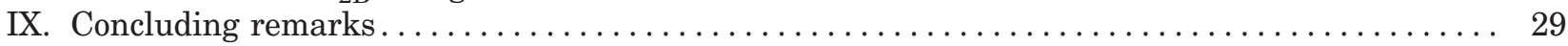

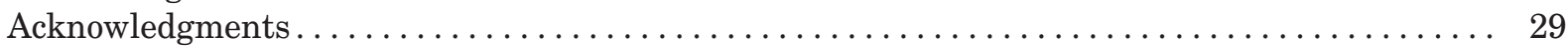

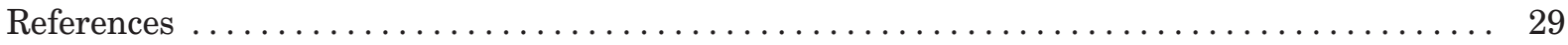

\begin{abstract}
In the 10 years since our previous International Union of Basic and Clinical Pharmacology report on the nomenclature and classification of adenosine receptors, no developments have led to major changes in the recommendations. However, there have been so many other developments that an update is needed. The fact that the structure of one of the adenosine receptors has recently been solved has already led to new ways of in silico screening of ligands. The evidence that adenosine receptors can form homo- and heteromultimers has accumulated, but the functional significance of such complexes remains unclear. The availability of mice with genetic modi-
\end{abstract}

fication of all the adenosine receptors has led to a clarification of the functional roles of adenosine, and to excellent means to study the specificity of drugs. There are also interesting associations between disease and structural variants in one or more of the adenosine receptors. Several new selective agonists and antagonists have become available. They provide improved possibilities for receptor classification. There are also developments hinting at the usefulness of allosteric modulators. Many drugs targeting adenosine receptors are in clinical trials, but the established therapeutic use is still very limited.

\section{Introduction}

The Nomenclature Committee of the International Union of Basic and Clinical Pharmacology has had a subcommittee dealing with nomenclature and classification of adenosine receptors for more than 20 years, and two reports from the committee have previously been published in this journal-the first one dealing with receptors for both adenosine and nucleotides (Fredholm et al., 1994), the second with adenosine receptors only (Fredholm et al., 2001a). Although there have been rapid recent developments in the field of adenosine receptor signaling, most of what was stated in these early reviews remains valid, and the reader is referred to those texts for older data and a historical perspective. In 
the present update we focus on new aspects and recapitulate the older information only when absolutely needed for reference (for example as reference com-

There are four adenosine receptors among vertebrates, which have been denoted adenosine $A_{1}, A_{2 A}, A_{2 B}$ and $\mathrm{A}_{3}$ receptors (Fredholm et al., 2001a). Adenosine is a full agonist at all these receptors, and at $A_{1}$ and $A_{3}$ receptors, inosine can act as a partial agonist in functional assays (Jin et al., 1997; Fredholm et al., 2001b). There is no good evidence that adenine nucleotides can act on adenosine receptors without being degraded to nucleosides first. However, such breakdown is extremely rapid and efficient in most cells and tissues even when using so called "stable" ATP analogs, which rarely are stable in biological preparations. Thus, there is no reason to modify the recommended nomenclature.

To assess the roles of these receptors we must consider how the concentration of the endogenous agonist is regulated. There has been much progress in this field in recent years. Adenosine is known to take part in several different metabolic pathways, and intracellular concentrations of adenosine can never be zero. Furthermore, most, if not all, cells possess equilibrative nucleoside transporters (King et al., 2006). Therefore, there will be, by necessity, a finite level of adenosine in the extracellular space, even under the most basal conditions. This basal level has been estimated to be in the range of 30 to $200 \mathrm{nM}$ (Ballarín et al., 1991). From this baseline level, adenosine can increase substantially via two mechanisms: formation intracellularly and export via transporters, and formation in the extracellular space from adenine nucleotides released from cells. The earlier literature on adenosine emphasized the former pathway (Newby, 1984), but more recently, interest has centered on the contribution of ATP as an important source of extracellular adenosine. Whereas the focus here was initially on the release of ATP as a neurotransmitter, stored together with other transmitters (Burnstock, 2006), several other mechanisms have now moved to the foreground. Among the other sources of extracellular adenosine to be considered are: pounds for comparison with newer drugs).

1. Cells with damage to the cell membrane [e.g., in necrotic or apoptotic (Elliott et al., 2009) cell death]. This can generate very high levels locally because intracellular ATP levels are 4 to 5 orders of magnitude higher than extracellular levels.

2. Storage vesicles containing hormones (and transmitter) also by so called kiss-and-run release, which generates ATP release nonsynchronously with hormone (neurotransmitter) release (MacDonald et al., 2006; Zhang et al., 2009).

3. Connexin/pannexin "hemichannels" (Spray et al., 2006).

4. Other channels, including maxi-anion channels, volume-regulated anion channels, or P2X7 receptor channels.

5. Transport vesicles delivering proteins to the cell membrane (Lazarowski et al., 2003).

6. A subset of lysosomes (Zhang et al., 2007).

It is well known that ATP is released from many cells in which cell membranes are subjected to stretch (Okada et al., 2006), perhaps via one of the abovementioned mechanisms. Once ATP (or ADP) is released, the phosphate groups of extracellular ATP/ ADP are rapidly split off by ectoenzymes working in concert, first via nucleoside triphosphate diphosphohydrolases (NTDPases; e.g., CD39) (Robson et al., 2005), followed by hydrolysis via ecto- 5 '-nucleotidase, CD73 (Picher et al., 2003). Knockouts of these enzymes have revealed their importance in contributing to extracellular adenosine in different organs and situations (see Table 1).

The potency of adenosine at these receptors is obviously determined by the affinity of the endogenous ligand (adenosine) to the different receptors. Unfortunately, it is exceedingly difficult to determine this affinity, because adenosine is rapidly metabolized and rapidly formed in biological preparations, including membrane preparations. Therefore, if metabolism of adenosine is prevented, endogenous adenosine accumulates to confound the measurements. This endoge-

TABLE 1

Some genetically modified animals useful to delineate adenosine receptor functions

\begin{tabular}{|c|c|c|}
\hline Gene Targeted & Comment & References \\
\hline \multirow[t]{2}{*}{ AdoRA1 } & Major portion of coding exon $2+\sim 5 \mathrm{~kb}$ adjacent $3^{\prime}$ genomic seq; not lethal. & Johansson et al., 2001 \\
\hline & $3^{\prime}$ portion of coding exon $1+$ intron $5^{\prime}$ portion of coding exon 2 , not lethal & Sun et al., 2001 \\
\hline \multirow[t]{2}{*}{ AdoRA2A } & Entire coding exon 2 , not lethal & Ledent et al., 1997 \\
\hline & $3^{\prime}$ portion of coding exon $2 \sim 1.0 \mathrm{~kb}$ immediate intron seq, not lethal & Chen et al., 1999, 2001a \\
\hline \multirow[t]{2}{*}{ AdoRA2B } & $\begin{array}{l}\text { Replacement of exon } 1 \text { of the } \mathrm{A}_{2 \mathrm{~B}} \mathrm{AR} \text { with a reporter construct containing the } \beta \text {-gal gene; not } \\
\text { lethal. }\end{array}$ & Yang et al., 2006 \\
\hline & $\begin{array}{l}\text { Replacement of part of the intron and the entirety of exon } 2 \text { (amino acids 113-332) with a } \\
\text { marker gene; not lethal. }\end{array}$ & Hua et al., 2007b \\
\hline AdoRA3 & Entire coding exon $1+7.5 \mathrm{~kb}$ immediate intron seq; not lethal & Salvatore et al., 2000 \\
\hline Adenosine kinase & In frame insertion at exon amino acid Gly169-Thr225; die at P4 & Boison et al., 2002 \\
\hline Adenosine deaminase & In frame insertion at exon 5 ; perinatal death Die at 3 weeks after trophoblast rescue & Blackburn et al., 1998 \\
\hline CD39 & Part of exon 1 ; not lethal. & Enjyoji et al., 1999 \\
\hline \multirow[t]{2}{*}{ CD73 } & Entire exon $3+$ intronic sequences; not lethal. & Thompson et al., 2004 \\
\hline & Entire exon 2 ; not lethal. & Koszalka et al., 2004 \\
\hline
\end{tabular}

$\mathrm{kb}$, kilobase(s). 
nous adenosine can be cryptically bound, especially to receptors coupling to $\mathrm{G}_{\mathrm{i}}$ proteins, and also influences the apparent $B_{\max }$ values (Parkinson and Fredholm, 1992). Attempts have been made to assess the affinity of endogenous adenosine at $A_{1}$ receptors by examining the binding of another agonist in the presence or absence of adenosine deaminase (Cohen et al., 1996), but adenosine deaminase is a low- $K_{\mathrm{m}}$ enzyme, and $\mathrm{A}_{1}$ receptors may also interact with it in other ways (e.g., Saura et al., 1996), and the estimate is uncertain. There have also been other attempts to indirectly estimate the binding affinity of adenosine, including an attempt to partly denature the receptor by urea and disrupting interactions with the $\mathrm{G}$ protein (May et al., 2005). Although binding of an antagonist was not markedly disrupted by treatment with urea, it is not certain that the same is true for an agonist. It is also not immediately obvious whether binding in the absence of GTP (which of course can never happen in vivo) or in its presence should be used to estimate the potency of agonists. Hence, we do not have truly reliable binding data on the comparative affinity of the endogenous agonist at the four adenosine receptors and must rely on determination of the potency of adenosine in functional assays (see an estimate based on functional studies in Table 3).

This introduces another important confounding factor: potency of the agonist is markedly influenced by the receptor number (Arslan et al., 1999; Johansson et al., 2001). The reason for this is that adenosine receptors are generally coupled via several amplification steps to the final response, and they therefore exhibit the behavior described by pharmacologists as "spare receptors." In such systems, alterations in receptor number are manifested by parallel shifts in the doseresponse curve, not as alterations in the maximal response (except when receptor number or agonist efficacy are very low, when a further decrease causes a drop in maximum response). When one compares ligand potencies to modulate cAMP levels at comparative receptor densities, it is observed that adenosine is nearly equipotent at $A_{1}, A_{2 A}$, and $A_{3}$ receptors but is some 50 times less potent at $\mathrm{A}_{2 \mathrm{~B}}$ receptors (Fredholm et al., 2001b). If, by contrast, we instead examine the ability to activate mitogen-activated protein kinase (which all the adenosine receptors do), adenosine is equipotent at all of these (Schulte and Fredholm, 2000). Moreover, the expression levels of all the adenosine receptors is transcriptionally regulated and can change rapidly and dramatically in response to various stimuli (e.g., see Murphree et al., 2005). Thus, the potency of endogenous adenosine depends on receptor number and on the type of response measured. Hence, there is no rationale to divide the receptors into highand low-affinity receptors as is frequently done.

\section{Receptor Structure}

The crystal structure of the adenosine $\mathrm{A}_{2 \mathrm{~A}}$ receptor was recently determined (Jaakola et al., 2008). It is one of the very first "snapshots" of a GPCR ${ }^{1}$ architec-

${ }^{1}$ Abbreviations: 2-AG, 2-arachidonylglycerol; AIA, aspirinintolerant asthma; ATL146e, apadenoson [trans-4-\{3-[6amino-9-( $N$-ethyl- $\beta$-D-ribofuranosyluronamide)- $9 H$-purin-2-yl] prop-2-ynyl\}cyclohexanecarboxylic acid methyl ester]; ATL 802, $N$-(5-(1-cyclopropyl-2,6-dioxo-3-propyl-2,3,6,7-tetrahydro- $1 H$ purin-8-yl)pyridin-2-yl)- $N$-methyl-6-(trifluoromethyl)nicotinamide; BAY 60-6583, 2-[6-amino-3,5-dicyano-4-[4-(cyclopropylmethoxy)phenyl]pyridin-2-ylsulfanyl]acetamide; BAY 68-4986, capadenoson [2-amino-6-(\{[2-(4-chlorophenyl)-1,3-thiazol-4yl]methyl\}sulfanyl)-4-[4-(2-hydroxyethoxy)phenyl]pyridine-3,5dicarbonitrile]; BiFC, bimolecular fluorescence complementation; BG9228, 3-(4-(2,6-dioxo-1,3-dipropyl-2,3,6,7-tetrahydro- $1 H$-purin-8yl)-bicyclo(2.20.2)oct-1-yl)propionic acid; BIIB014, vipadenant [3-(4-amino-3-methylbenzyl)-7-(2-furyl)-3H-[1,2,3]triazolo[4,5-d]pyrimidine-5-amine]; BRET, bioluminescence resonance energy transfer; CF102, Cl-IB-MECA; CGS 21680, 2-[p-2-(carbonylethyl)phenylethylamino]-5'-N-ethylcarboxamidoadenosine; CGS15943, 5-amino-9chloro-2-(2-furyl)[1,2,4] triazolo[1,5-c]quinazoline; CHO, Chinese hamster ovary; Cl-IB-MECA, 2-chloro- $N N^{6}$-(3-iodobenzyl)-5'- $N$-methylcarboxamidoadenosine; CPA, $N^{6}$-cyclopentyladenosine; CPFPX, 8-cyclopentyl-1-propyl3-(3-fluoropropyl)xanthine; CV-3146, regadenoson [2-(4-((methylamino) carbonyl-1H-pyrazol-1-yl)adenosine]; CVT-6883, 3-ethyl-1-propyl-8-(1-(3trifluoromethylbenzyl)-1 $H$-pyrazolo-4-yl)xanthine; DPCPX, 8-cyclopentyl1,3-dipropylxanthine; DTI-0009, selodenoson [ $N^{6}$-cyclopentyl-5'-( $N$ ethyl)carboxamidoadenosine]; DU124183, 2-cyclopentyl-4-phenylamino$1 H$-imidazo-[4,5-c]quinoline; FK-453, $R$-[(E)-3-(2-phenylpyrazolo[1,5a]pyridin-3-yl)acryloyl]-2-piperidine ethanol; FRET, fluorescence resonance energy transfer; GPCR, G protein-coupled receptor; GR79236, $N$-((1S,trans)-2-hydroxycyclopentyl)adenosine; GS9667 (CVT-3619), (2-\{6$[((1 R, 2 R)-2$-hydroxycyclopentyl)amino $]$ purin-9-yl $\}(4 S, 5 S, 2 R, 3 R)-5-[(2-$ fluorophenylthio)methyl]oxolane-3,4-diol; GW493838, $(2 R, 3 S, 4 R, 5 R)-2$ ((5-(tert-butyl)-1,3,4-oxadiazol-2-yl)methyl)-5-(6-((4-chloro-2-fluorophenyl) amino)-9H-purin-9-yl)tetrahydrofuran-3,4-diol; HEK, human embryonic kidney; IB-MECA, $N^{6}$-(3-iodobenzyl)-5'- $N$-methylcarboxamidoadenosine (CF101); KW-3902, rolofylline [1,3-dipropyl-8-(3-noradamantyl)xanthine]; KW6002, istradefylline [(E)-1,3-diethyl-8-( $m, p$-dimethoxystyryl)xanthine]; LAS38096, 2-amino-4-(2-furanyl)-5-(4-pyrimidinyl)pyrimidine; LPS, lipopolysaccharide; LUF6000, $\mathrm{N}$-(3,4-dichlorophenyl)-2-cyclohexyl- $1 \mathrm{H}$ imidazo-[4,5-c] quinolin-4-amine; LUF6096, $N$-\{2-[(3,4-dichlorophenyl) amino]quinoline-4-yl\}cyclohexanecarboxamide; LUF6258, $N^{6}$-[2-amino-3(3,4-dichlorobenzoyl)-4,5,6,7-tetrahydrothieno[2,3-c]pyridin-6-yl-9-nonyloxy-4-phenyl]adenosine; mGlu, metabotropic glutamate; MRE-0094, sonedenoson (2-[2-(4-chlorophenyl)ethoxy]adenosine); MRE-2029-F20, $\mathrm{N}$-benzo[1,3] dioxol-5-yl-2-(5-(2,6-dioxo-1,3-dipropyl-2,3,6,7-tetrahydropurin-8-yl)-1-methyl-1H-pyrazol-3-yloxy)acetamide; MRE-3008-F20, 5-[[(4methoxyphenyl)amino] carbonyl]amino-8-propyl-2-(2-furyl)pyrazolo[4, 3-e]1,2,4-triazolo[1,5-c]pyrimidine; MRS1191, 1,4-dihydro-2-methyl6-phenyl-4-(phenylethynyl)-3,5-pyridinedicarboxylic acid, 3-ethyl 5-(phenylmethyl) ester; MRS1220, N-[9-chloro-2-(2-furanyl)[1,2,4]-triazolo[1,5c] quinazolin-5-yl]benzene acetamide; MRS1523, 5-propyl-2-ethyl-4-propyl3-(ethylsulfanylcarbonyl)-6-phenylpyridine-5-carboxylate; MRS1754, N-(4cyanophenyl)-2-(4-(1,3-dipropylxanthin-8-yl)phenoxy)acetamide; MRS592, 2-chloro- $N^{6}$-(3-iodobenzyl)-adenosine; MSX-2, 3-(3-hydroxypropyl)-7methyl-1-propargyl-8-( $m$-methoxystryryl)xanthine; MSX-3, phosphoric acid mono-(3-\{8-[2-(3-methoxy-phenyl)-vinyl]-7-methyl-2,6-dioxo-1-prop-2ynyl-1,2,6,7-tetrahydropurin-3-yl\}-propyl) ester; MSX-4, L-valine-3-\{8-(E)2-[3-methoxyphenyl)ethenyl]-7-methyl-1-propargylxanthine-3-yl\}propyl ester hydrochloride; NAM, negative allosteric modulator; NECA, $5^{\prime}-N$ ethylcarboxamidoadenosine; nt, nucleotide(s); PAM, positive allosteric modulator; PD120,918, 4-methyl-2-oxo-2H-chromen-7-yl methylcarbamate; PD81,723, (2-amino-4,5-dimethyl-3-thienyl)(3-(trifluoromethyl)phenyl)-methanone; PSB-10, 8-ethyl-4-methyl-2-(2,3,5-trichlorophenyl)-(8R)- 
ture after structural determinations of rhodopsin and $\beta_{1}$ - and $\beta_{2}$-adrenergic receptors (for review, see Rosenbaum et al., 2009).

\section{A. Engineered Receptors}

Except for rhodopsin, wild-type GPCRs tend to be too thermolabile to allow prolonged solubilization, purification, and X-ray studies. Magnani et al. (2008) elegantly addressed this issue by mutating the adenosine $\mathrm{A}_{2 \mathrm{~A}}$ receptor sequentially to improve its thermostability. They managed to create relatively stable receptor variants with up to five amino acid substitutions, albeit with different patterns for either agonist or antagonist binding. A further obstacle is the receptors' inherent conformational flexibility and heterogeneity (especially upon agonist binding). Thus, Jaakola et al. (2008), in an approach different from that of Magnani et al. (2008), engineered the adenosine $A_{2 A}$ receptor to improve on these aspects by the insertion of the very stable lysozyme protein from T4 bacteriophage (T4L) for most of the third intracellular loop (Leu209-Ala221), and by deletion of the larger part of the very flexible $\mathrm{C}$ terminus (Ala317-Ser412). This construct $\left(\mathrm{A}_{2 \mathrm{~A}}-\mathrm{T} 4 \mathrm{~L}-\Delta \mathrm{C}\right)$ was further stabilized during purification with high concentrations of sodium chloride and cholesterol and a receptor-saturating concentration of the antagonist theophylline, which was replaced by the high-affinity antagonist 4-(2-(7-amino-2-(2-furyl)1,2,4-triazolo[2,3-a]-1,3,5-triazin-5-yl)amino)ethyl)phenol (ZM241385) in the final purification step.

\section{B. Receptor Crystallization}

Crystallization was achieved through an in meso crystallization approach, in which the lipid phase consisted of a mixture of mono-olein and cholesterol. A total of approximately 100 crystals was obtained, of which the 13 best yielded diffraction data good enough for a $2.6-\AA$ resolution. In Fig. $1 \mathrm{~A}$, a representation of

4,5,7,8-tetrahydro- $1 H$-imidazo[2.1-i]purin-5-one; PSB-11, 8-ethyl-4methyl-2-phenyl-(8R)-4,5,7,8-tetrahydro- $1 H$-imidazo[2.1-i]purin-5-one; PSB-1115, 1-propyl-8- $p$-sulfophenylxanthine; PSB-36, 1-butyl-8-noradamant-3-yl-3-(3-hydroxypropyl)-3,7-dihydropurin-2,6-dione; PSB-603, 8-(4(4-(4-chlorophenyl)piperazine-1-sulfonyl)phenyl)-1-propylxanthine; SAR, structure-activity relationship; SCH-420814, preladenant [2-(furan-2-yl)-7(2-\{4-[4-(2-methoxyethoxy)phenyl]piperazin-1-yl\}ethyl)-7H-pyrazolo[4,3e][1,2,4]triazolo[1,5-c]pyrimidin-5-amine]; SCH-442416, 2-(2-furyl)-7-[3-(4methoxyphenyl)propyl]-7H-pyrazolo[4,3-e][1,2,4] triazolo[1,5-c]pyrimidin5-amine; SCH-58261, 5-amino-7-(2-phenylethyl)-2-(2-furyl)pyrazolo[4,3-e]1,2,4-triazolo[1,5-c]-pyrimidine; SLV320, 4-(4-hydroxycyclohexylamino)-6phenylpyrrolo[2,3- $d$ ] pyrimidine; SNP, single nucleotide polymorphisms; ST-1535, 2-butyl-9-methyl-8-[1,2,3] triazol-2-yl-9H-purin-6-ylamine; SYN115, 4-hydroxy-4-methylpiperidine-1-carboxylic acid-(4-methoxy-7morpholin-4-ylbenzothiazol-2-yl)amide; T4L, lysozyme protein from T4 bacteriophage; T-62, 2-amino-3-(4-chlorobenzoyl)-5,6,7,8-tetrahydrobenzothiophene; VUF5455, 4-methoxy- $N$-(7-methyl-3-(2-pyridinyl)-1-isoquinolinyl)benzamide); VUF-5574, $N$-(2-methoxyphenyl)- $N$-[2-(3-pyridyl)quinazolin-4-yl]urea; WRC-04702, binodenoson [2-((cyclohexylmethylene) hydrazino)adenosine]; YFP, yellow fluorescent protein; ZM241385, 4-(2-[7amino-2-(2-furyl)[1,2,4] triazolo[2,3-a][1,3,5] triazin-5-ylamino]ethyl)phenol.
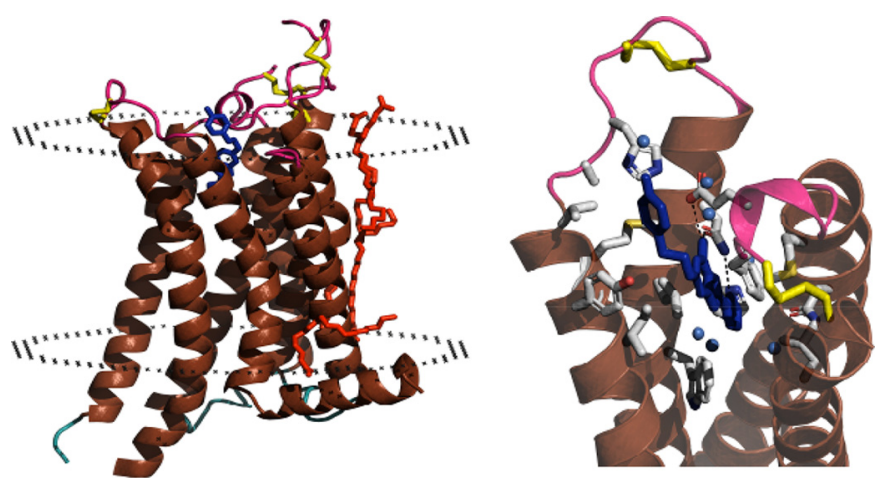

FIG. 1. Left, crystal structure of the adenosine $\mathrm{A}_{2 \mathrm{~A}}$ receptor. Brown, $\alpha$-helical elements; dark blue, ZM241385; yellow, disulfide bridges; pink, extracellular domain; red, stearic acid molecules; and light blue, intracellular domain. Membrane boundaries are represented as ellipsoids. Right, ligand binding site of the adenosine $\mathrm{A}_{2 \mathrm{~A}}$ receptor. Brown, four transmembrane domains (helices 3, 5, 6, and 7); dark blue, ZM241385; blue spheres, explicit water molecules; pink, extracellular elements; yellow, disulfide bridges; and atom-coded colors, amino acid side chains involved in ligand binding.

the receptor structure (without T4L) is shown, with a closer look at the ligand binding site in Fig. 1B. The final refined structure thus refers to a fusion protein of the adenosine $\mathrm{A}_{2 \mathrm{~A}}$ receptor with $\mathrm{T} 4 \mathrm{~L}$ (including amino acid residues Ile 3 to Gln310 of the receptor and residues 2 to 161 of T4L), a number of lipids modeled as stearic acid molecules, sulfate ions, ordered water molecules, and the antagonist ZM241385. At some parts of the polypeptide chain, the weak electron density did not allow a precise structure determination. This was true for the first two amino acids of the receptor (Met1-Pro2), amino acids Glu311 to Ala316 in the carboxyl tail, and the tip of the second extracellular loop (Gln148-Ser156). Unlike the two $\beta$-adrenergic receptors, the $A_{2 A}$ receptor structure did not provide evidence for the presence of cholesterol molecules.

\section{Pharmacological Characterization}

Such a highly engineered receptor construct necessitated a thorough pharmacological characterization with respect to signaling and ligand binding properties. Signaling, measured as modulation of cAMP production, was completely abrogated, most probably because of the insertion of T4L in the third intracellular loop of the receptor. Compared with the wild-type receptor, the construct displayed virtually identical affinity for the antagonist ZM241385 in radioligand binding studies, whereas agonist affinity was somewhat higher than observed for the wild-type construct. High sodium chloride concentrations, essential for the generation of crystals, did not affect antagonist affinity, whereas agonist affinity was reduced to a similar value for wild-type and engineered receptor, in line with earlier observations (Gao and IJzerman, 2000). This suggests that the antagonist-binding site in the crystal structure was not affected by the substantial modifications to the receptor protein. 


\section{Structural Characteristics}

1. The Ligand Binding Site. The $\mathrm{A}_{2 \mathrm{~A}}$ receptor structure is quite different from the other GPCRs for which crystal structures are available. First, ZM241385 binds in an extended conformation protruding into the extracellular domain, whereas the ligand-binding site of $\beta$-receptor antagonists seems to reside within the transmembrane domain. Therefore, the amino acids interacting with the ligand are found mainly on helices $3,5,6$, and 7 in the transmembrane domain as well as in extracellular loops 2 and 3 (see also Fig. 1B). Second, the architecture of the extracellular loops is markedly different, especially for the second one. It is best described as a spatially constrained random coil with three disulfide bridges to the first extracellular loop. Two of these are unique to the adenosine $\mathrm{A}_{2 \mathrm{~A}}$ receptor, and the third one is conserved among virtually all class A GPCRs. An early mutagenesis study (Kim et al., 1996) predicted this. The second extracellular loop also holds a very short helical segment from which two amino acids (Phe168 and Glu169) have strong ligand interactions. The third extracellular loop has a fourth (intraloop) disulfide bridge. This extensive network of disulfide bridges yields a quite rigid but open architecture that might allow relatively unhindered access of ligand molecules.

2. "Toggle Switch" and "ionic Lock" The relative position of the seven transmembrane domains is somewhat different from the other receptor structures, most notably for helices 1 and 2 , with a shift of $\leq 7 \AA$ at the extracellular boundaries of the helices compared with the $\beta$-adrenergic receptors. Consequently, features that were generalized from, for example, the rhodopsin transmembrane structure, need to be reassessed for each new receptor structure. The conserved tryptophan residue in helix 6 (Trp246 or Trp6.48 - the residue at the bottom of the cavity in Fig. 1B) has been proposed as a "toggle switch" between an active and inactive receptor state. This assumption is based largely on the position of retinal in rhodopsin, where it is near the tryptophan residue, keeping rhodopsin in an inactive form. However, in neither the $\beta$-adrenergic nor the adenosine $A_{2 A}$ receptors is this contact area between ligand and amino acid very prominent (see also Fig. 1B), hence casting some doubt on the unique role of $\operatorname{Trp} 6.48$ in receptor activation. A similar generalization from the rhodopsin structure regards the so-called "ionic lock," the strong hydrogen bonding network between the conserved E/DRY motif at the cytoplasmic side of helix 3 and a glutamate residue in helix 6 . This structural motif was proposed to restrain the receptor in its inactive form but takes alternative forms in the other receptor structures. In the adenosine $\mathrm{A}_{2 \mathrm{~A}}$ receptor, Asp101 (D in DRY) forms a hydrogen bond with Tyr112 in a helical segment of the second intracellular loop and with Thr41 at the bottom of helix 2 .

\section{E. Receptor Structure and Receptor Homology Modeling}

Overall, the findings described above suggest that the format of the ligand binding cavity may vary considerably between receptors. This caveat was firmly illustrated by a recent modeling assessment with the aim to evaluate GPCR structure prediction and ligand docking attempts (Michino et al., 2009). Before the release of the $A_{2 \mathrm{~A}}$ receptor crystal structure into the public domain, 29 research groups submitted more than 200 receptor models that were evaluated for overall protein architecture and their quality with respect to ligand docking. Whereas the transmembrane domains of the receptor were reasonably well aligned (usually within $4 \AA$ root-mean-square deviation), the ligand-binding domain and the structure of the second extracellular loop were not well predicted at all. The majority of models had root-mean-square deviation values of more than $10 \AA$ for the ligand binding site, and only one predicted the typical perpendicular orientation of ZM241385 halfway the extracellular and transmembrane domains. The reasons for this generally large divergence were implicitly examined by Ivanov et al. (2009). The authors noted that domain knowledge such as mutagenesis data yielded useful constraints when docking ZM241385 into a receptor homology model. The inclusion of the ordered water molecules from the crystal structure into the receptor model proved equally important to obtain acceptable ligand poses. From a different perspective, Mobarec et al. (2009) concluded that based on sequence identity the currently available structures may only provide reasonable homology models for a small minority of class A GPCRs. In two recent publications, new ligands interacting with the adenosine $A_{2 A}$ receptor were identified with the crystal structure as the template (Carlsson et al., 2010; Katritch et al., 2010). In a virtual, computer-based screening approach, millions of commercially available molecules were automatically docked into the ZM241385 binding site and ranked according to interaction energies. On the basis of these results, dozens of compounds were purchased and tested in radioligand binding studies on the adenosine receptors with a remarkably high "hit rate" of 30 to $40 \%$. These included completely new chemotypes.

\section{Receptor Oligomerization}

Adenosine receptors, like other class A GPCRs, have long been thought to exclusively occur in a monomeric state. Monomeric receptors are sufficient to induce signaling (Chabre and le Maire 2005 Whorton et al., 2007, 2008, White et al., 2007). At least some studies suggest signaling via dimers occurs only at higher receptor densities (White et al., 2007). More recently, however, evi- 
dence is accumulating that adenosine receptors can form dimeric or, more generally speaking, multimeric or oligomeric structures. Through self-association, homo-oligomers ("homomers") can be formed. Hetero-oligomerization leading to "heteromers" may be the consequence of the association between adenosine receptors and preferred partners, mostly other GPCRs, including other adenosine receptor subtypes. This phenomenon has been demonstrated through a variety of experimental techniques, mostly in artificial cell lines. The use of overexpressed recombinant receptors may result in the creation of many more oligomers than naturally exist. In some cases, BRET may detect interactions between receptors that are in close proximity in a compact structure such as a coated pit, rather than forming true molecular dimers. Furthermore, GPCRs contain hydrophobic regions that can oligomerize, even after solubilization in SDS. Hence, receptor dimerization or oligomerization may occur after solubilization in detergent and not be representative of receptor structure and organization in the membrane.

Thus, it remains to be seen how relevant the findings are for (adenosine) receptors in their natural environment (i.e., primary cells and tissues in an intact animal or human body). This latter concern, which applies to all GPCRs, was eloquently brought forward by an ad hoc International Union of Basic and Clinical Pharmacology committee, which suggested two of the three following criteria to be fulfilled before accepting a given oligomer to be of physiologic significance (Pin et al., 2007):

- physical association of the receptor complex in native tissue or primary cells, indicated by colocalization in subcellular compartment (preferably with oligomerspecific receptor antibodies); energy transfer technologies [FRET, BRET, bimolecular fluorescence complementation $(\mathrm{BiFC})]$ in native tissue (labeled ligands or antibodies);

- definition of a specific functional property of the receptor complex (e.g., allosteric modulation of one monomer by the other or activation of a particular signaling pathway); and

- occurrence in vivo (knockout animals, RNA interference technology, etc.).

Another initiative, although not linked to the International Union of Basic and Clinical Pharmacology, summarized similar criteria and recommendations along with further definitions for nomenclature, which we use here (Ferré et al., 2009). Before we discuss available evidence, it should be stressed that for the adenosine receptors, the criteria mentioned above have not yet been fully met. It should also be emphasized that interactions between different receptors on downstream signaling events do not constitute proof of interactions at the receptor level.

\section{A. Adenosine Receptor Homomers}

In theory, four homomeric pairs can be envisaged for adenosine receptors: $A_{1}-A_{1}, A_{2 A}-A_{2 A}, A_{2 B}-A_{2 B}$, and $A_{3}-$ $A_{3}$. So far, only reports with experimental evidence for the occurrence of $A_{1}-A_{1}$ and $A_{2 A}-A_{2 A}$ homomers have been published.

1. $A_{1}-A_{1}$. Two early reports hinted to $\mathrm{A}_{1}$ receptor homodimerization. Both Ciruela et al. (1995) and Yoshioka et al. (2002) used (different) antibodies against the wild-type adenosine $A_{1}$ receptor to note that immunoprecipitation experiments analyzed with Western blotting revealed higher order bands in some instances (e.g., in HEK293 cells expressing the human adenosine $A_{1}$ receptor, but also in brain tissues). In a more recent publication (Suzuki et al., 2009), these findings were corroborated and extended with differently tagged receptors expressed in HEK293T cells. Both hemagglutinin- and myc-tagged adenosine $A_{1}$ receptors were used in coimmunoprecipitation experiments, providing evidence for both monomeric and dimeric structures. It is notable, however, that even after solubilization in SDS, adenosine receptors and many other GPCRs form aggregates upon heating. This indicates that homo- or heteroaggregates can form after detergent solubilization and may be artifacts. Green fluorescent protein- and Renilla reniformis luciferase-tagged receptors enabled BRET experiments to be performed in which bioluminescence signals were indicative for receptor-receptor association among overexpressed recombinant receptors. In another recent study, $\mathrm{A}_{1}-\mathrm{A}_{1}$ homomers, predominantly located at the cell surface, were identified with BiFC techniques in $\mathrm{CHO}$ cells expressing YFP-tagged receptors (Briddon et al., 2008).

2. $A_{2 A}-A_{2 A}$. The first evidence for $\mathrm{A}_{2 \mathrm{~A}}$ receptor homodimerization was provided by Canals et al. (2004). The authors used both FRET and BRET techniques as well as immunoblotting to show that in transfected HEK293 cells, overexpressed recombinant adenosine $\mathrm{A}_{2 \mathrm{~A}}$ receptors exist as both homodimers and monomers. They demonstrated, by means of cell surface biotinylation experiments, that after detergent solubilization, approximately $90 \%$ of the cell surface recombinant $A_{2 A} R$ species exists in the homodimeric form. The same pattern of dimer formation was observed for an engineered $\mathrm{A}_{2 \mathrm{~A}}$ receptor lacking the $\mathrm{C}$ terminus, whereas this receptor mutant was no longer able to dimerize with the dopamine $\mathrm{D}_{2}$ receptor (see section III.B.5). $\mathrm{A}_{2 \mathrm{~A}}$ receptor homodimerization was also demonstrated with BiFC techniques by Vidi et al. (2008a), who also used a combination of FRET and BiFC techniques to demonstrate that recombinant adenosine $\mathrm{A}_{2 \mathrm{~A}}$ receptors exist as higher order oligomers, consisting of at least three monomers, at the plasma membrane of differentiated neuronal cells (Vidi et al., 2008b). A similar conclusion was reached by Gandia et al. (2008), who combined BiFC with BRET techniques to detect the occurrence of aden- 
osine $\mathrm{A}_{2 \mathrm{~A}}$ receptor oligomers with more than two monomers in HEK293 cells. In another recent study, recombinant $\mathrm{A}_{2 \mathrm{~A}}-\mathrm{A}_{2 \mathrm{~A}}$ homodimers, predominantly located intracellularly, were identified with BiFC techniques in CHO cells expressing YFP-tagged receptors (Briddon et al., 2008).

\section{B. Adenosine Receptor Heteromers}

Available evidence points to the interaction of both adenosine $A_{1}$ and $A_{2 A}$ receptors with other GPCRs, whereas no direct data have been reported for adenosine $\mathrm{A}_{2 \mathrm{~B}}$ and $\mathrm{A}_{3}$ receptors.

1. $A_{1}-A_{2 A}$. Ciruela et al. (2006) investigated the heteromerization of adenosine $A_{1}$ and $A_{2 A}$ receptors. The two receptors are colocalized in striatal glutamatergic nerve terminals, both pre- and postsynaptically. This was demonstrated in immunogold blotting and, after detergent solubilization, coimmunoprecipitation experiments. In HEK293 cells transfected with suitably tagged adenosine $\mathrm{A}_{1}$ as well as $\mathrm{A}_{2 \mathrm{~A}}$ receptors, evidence in BRET and TR-FRET experiments was found for a direct interaction between the two recombinant receptors. Radioligand binding studies in membranes of these HEK293 cells demonstrated that agonist binding to the adenosine $\mathrm{A}_{2 \mathrm{~A}}$ receptor influenced the affinity of $(R)-N^{6}$-phenylisopropyladenosine for the adenosine $\mathrm{A}_{1}$ receptor, but not vice versa. Ciruela et al. (2006) speculated that these findings constitute a mechanism for fine-tuning the release of glutamate by adenosine. $\mathrm{BiFC}$ techniques were used in a later study with $\mathrm{CHO}$ cells expressing both receptors fused with truncated YFP constructs, showing significant fluorescence at the plasma membrane and intracellularly for the recombinant $\mathrm{A}_{1}-\mathrm{A}_{2 \mathrm{~A}}$ heteromer (Briddon et al., 2008).

2. $A_{1}-P 2 Y_{1}$. The heteromerization of adenosine $\mathrm{A}_{1}$ receptors with $\mathrm{P}_{2} \mathrm{Y}_{1}$-purinergic receptors was studied by Yoshioka et al. (2001). The two detergent-solubilized recombinant receptors (hemagglutinin- and myc-tagged) were shown to coimmunoprecipitate in cotransfected HEK293T cells, unlike the negative control of $A_{1}$ and dopamine $D_{2}$ receptors. Colocalization was also demonstrated by double immunofluorescence experiments with confocal laser microscopy. This heteromerization had functional consequences. The affinities of the $A_{1}$ receptor agonist CPA and inverse agonist DPCPX were reduced in a $\left[{ }^{3} \mathrm{H}\right] \mathrm{NECA}$ radioligand binding assay, whereas the $\mathrm{P} 2 \mathrm{Y}$ receptor agonist adenosine $5^{\prime}-\mathrm{O}-(2-$ thiodiphosphate) was capable of displacing the radioligand. Moreover, this agonist showed a concentrationdependent reduction of forskolin-stimulated cAMP accumulation in the cells that was sensitive to pertussis toxin and DPCPX. It is noteworthy that these findings were largely confirmed in/ex vivo, where the authors studied rat brain cortex, hippocampus, and cerebellum as well as primary cultures of cortical neurons (Yoshioka et al., 2002). In a later review, it was speculated that this heteromerization between adenosine $\mathrm{A}_{1}$ and $\mathrm{P} 2 \mathrm{Y}_{1}$ recep- tor might be one of the mechanisms for the adenine nucleotide-mediated inhibition of neurotransmitter release (Nakata et al., 2005). However, the fact that the ATP-mediated inhibition of neurotransmitter release is eliminated in slices from $A_{1}$ knock-out mice suggests that a direct action at $A_{1}$ receptors after rapid breakdown is another likely explanation (Masino et al., 2002).

3. $A_{1}-P 2 Y_{2}$. A study similar to that described in section III.B. 2 was done for the pair of adenosine $A_{1}$ and $\mathrm{P}_{2} \mathrm{Y}_{2}$ receptors (Suzuki et al., 2006). Coimmunoprecipitation experiments of detergent-solubilized receptors provided evidence that these receptors directly associate in cotransfected HEK293T cells. Radioligand agonist but not antagonist binding at the $\mathrm{A}_{1}$ receptor was significantly inhibited by high concentrations of the $\mathrm{P}_{2} \mathrm{Y}_{2}$ agonist UTP in membranes from cotransfected cells. UTP also inhibited the reduction of forskolin-stimulated cAMP production by CPA in the cotransfected cells, again only at high concentrations. It is possible, however, that UTP can indirectly influence ATP and adenosine concentrations in membrane preparations (Lazarowski et al., 2000). The increase in intracellular $\mathrm{Ca}^{2+}$ levels induced by UTP via the $\mathrm{P}_{2} \mathrm{Y}_{2}$ receptor was very much enhanced by the simultaneous addition of the adenosine receptor agonist NECA in the coexpressing cells. These results suggest either that heteromerization of these two receptors generates a unique protein architecture in which the simultaneous activation of the two receptors induces a differential effect on $A_{1} / G_{i / o}$ and $\mathrm{P} 2 \mathrm{Y}_{2} / \mathrm{G}_{\mathrm{q} / 11}$ signaling or that monomeric receptors have additive effects of downstream signaling pathways.

4. $A_{1}-D_{1}$. Detergent-solubilized $\mathrm{A}_{1}$ and $\mathrm{D}_{1}$ receptors were shown to coimmunoprecipitate in cotransfected Ltk-fibroblast cells (Ginés et al., 2000). This interaction seemed specific, because no coimmunoprecipitation was detected between $A_{1}$ and $D_{2}$ receptors cotransfected in the same cells. The $A_{1}-D_{1}$ receptor coimmunoprecipitation was constitutive, in that it occurred in the absence of $A_{1}$ or $D_{1}$ receptor agonist, whereas $D_{1}$ receptor activation, but not that of $A_{1}$, led to disruption of the $A_{1}-D_{1}$ heteromer. In an earlier publication, Ferré et al., (1998), using the same cell system, found that the adenosine $\mathrm{A}_{1}$ receptor agonist CPA induced a decrease in the proportion of radiolabeled dopamine $\mathrm{D}_{1}$ receptors in the high affinity state, indicating possible interactions at the level of receptors or at the level of receptor-G protein coupling.

5. $A_{2 A^{-}}-D_{2}$. The heteromeric pair of adenosine $\mathrm{A}_{2 \mathrm{~A}}$ and dopamine $\mathrm{D}_{2}$ receptor is probably the best studied combination. Hillion et al. (2002) performed double immunofluorescence experiments with confocal laser microscopy showing substantial colocalization of recombinant adenosine $\mathrm{A}_{2 \mathrm{~A}}$ and dopamine $\mathrm{D}_{2}$ receptors in cell membranes of SH-SY5Y human neuroblastoma cells stably transfected with human $\mathrm{D}_{2}$ receptor as well as in cultured striatal cells. Heteromerization between the two detergent-solubilized receptors was demonstrated 
in coimmunoprecipitation experiments, for which membrane preparations were used from $\mathrm{D}_{2}$ receptor-transfected SH-SY5Y cells and from mouse fibroblast $\mathrm{Ltk}^{-}$ cells stably transfected with the long form of the human $\mathrm{D}_{2}$ receptor. In the latter case, the $\mathrm{A}_{2 \mathrm{~A}}$ receptor (doubletagged with hemagglutinin) was transiently cotransfected. Similar studies were done by Kamiya et al. (2003) in HEK293 cells. Resonance energy transfer techniques (BRET and FRET) with suitably tagged receptors were used to demonstrate the same heteromerization in intact HEK293 cells (Canals et al., 2003; Kamiya et al., 2003). Heteromerization seemed to be constitutive and not ligand-induced, and involved the long C-terminal tail of the adenosine $\mathrm{A}_{2 \mathrm{~A}}$ receptor (Canals et al., 2004), in contrast to $\mathrm{A}_{2 \mathrm{~A}}$ receptor homomerization (see section III.A.2). BiFC technology to study $\mathrm{A}_{2 \mathrm{~A}}-\mathrm{D}_{2}$ heteromers in a CAD neuronal cell background was introduced by Vidi et al. (2008a). Again, strong fluorescence signals were observed when the two tagged receptors were cotransfected. In contrast to the earlier studies, the level of heteromerization at the cell surface was influenced by (prolonged) incubation of ligands for the two receptors.

6. $A_{2 A^{-}} C B_{1}$ and $A_{2 A^{-}} D_{2}-C B_{1}$. There is one report on the heteromerization between $\mathrm{A}_{2 \mathrm{~A}}$ and cannabinoid $\mathrm{CB}_{1}$ receptors (Carriba et al., 2007). It was found that solubilized $\mathrm{A}_{2 \mathrm{~A}}$ and $\mathrm{CB}_{1}$ receptors coimmunoprecipitate from extracts of rat striatum, where they are colocalized in fibrillar structures. In cotransfected HEK293 cells, BRET measurements with tagged receptors provided evidence for a direct physical interaction in an $\mathrm{A}_{2 \mathrm{~A}}-\mathrm{CB}_{1}$ receptor heteromer. In a later study, the combination of BiFC and BRET methods hinted at the oligomerization in HEK293 cells of this heteromer with the dopamine $\mathrm{D}_{2}$ receptor (Navarro et al., 2008).

7. $A_{2 A^{-}}-D_{2}-m G l u_{5}$. A combination of BiFC and BRET techniques and a newly developed sequential resonance energy transfer approach (Carriba et al., 2008) was vital in detecting higher order receptor heteromers in HEK293 cells, consisting of $\mathrm{mGlu}_{5}, \mathrm{D}_{2}$, and adenosine $\mathrm{A}_{2 \mathrm{~A}}$ receptors (Cabello et al., 2009). By using a high-resolution immunogold technique, the authors showed the three receptors to codistribute within the plasma membrane of dendritic spines of striatal synapses. Glutamate receptors are constitutive dimers (Romano et al., 1996), and thus it may be that the $\mathrm{mGlu}_{5}$ receptor homomer associates with the $\mathrm{A}_{2 \mathrm{~A}}-\mathrm{D}_{2}$ receptor heteromer.

8. $A_{2 A}-D_{3}$. Torvinen et al. (2005) used confocal microscopy to show that green fluorescent protein-tagged $\mathrm{A}_{2 \mathrm{~A}}$ and $\mathrm{D}_{3}$ receptors colocalize in the plasma membrane of transfected HeLa cells. Furthermore, FRET analysis provided evidence for heteromeric $\mathrm{A}_{2 \mathrm{~A}} / \mathrm{D}_{3}$ receptor complexes. In radioligand binding studies on $\mathrm{CHO}$ cell membranes stably expressing the two receptors, the $\mathrm{A}_{2 \mathrm{~A}}$ receptor agonist 2-[ $p$-2-(carbonylethyl)phenylethylamino]$5 '-N$-ethylcarboxamidoadenosine (CGS-21680) reduced the affinity of the high-affinity agonist binding state of $\left[{ }^{3} \mathrm{H}\right]$ dopamine.

\section{Adenosine Receptor Heteromerization with Other Proteins}

There is some evidence that heteromerization may also occur between adenosine receptors and proteins from other superfamilies, in particular adenosine deaminase and calmodulin.

1. $A_{1}-D_{1}$ with Adenosine Deaminase. Torvinen et al. (2002) used mouse fibroblast $\mathrm{Ltk}^{-}$cells transfected with human $\mathrm{D}_{1}$ receptor cDNA $\left(\mathrm{D}_{1}\right.$ cells $)$ and with both human $D_{1}$ and human $A_{1}$ receptor cDNAs $\left(A_{1} D_{1}\right.$ cells $)$. Confocal laser microscopy analysis showed a high degree of adenosine deaminase immunoreactivity on the membrane of the $A_{1} D_{1}$ cells but not of the $D_{1}$ cells. In double immunolabeling experiments in $\mathrm{A}_{1} \mathrm{D}_{1}$ cells and rat embryonic cortical neurons, a marked overlap in the distribution of the $A_{1}$ receptor and adenosine deaminase immunoreactivities and of the $D_{1}$ receptor and adenosine deaminase immunoreactivities was found.

2. $A_{2 A}-D_{2}$ with Calmodulin. Navarro et al. (2009) further explored the observation that calmodulin binds to cytoplasmic domains of some GPCRs, including the dopamine $\mathrm{D}_{2}$ receptor. The same interaction was now demonstrated with BRET technology for the adenosine $\mathrm{A}_{2 \mathrm{~A}}$ receptor. The sequential resonance energy transfer method developed by the same research group (Carriba et al., 2008) provided proof for a physical interaction between the three recombinant partners (i.e., calmodulin and the $\mathrm{A}_{2 \mathrm{~A}}-\mathrm{D}_{2}$ heteromer). BRET competition experiments suggested that calmodulin preferentially binds to $\mathrm{C}$-terminal tail of the $\mathrm{A}_{2 \mathrm{~A}}$ receptor in the heteromer.

\section{Functional Consequences}

There is thus very good evidence that recombinant adenosine receptors can, and do, form homo- and heteromultimers. It is less clear, however, whether this has important pharmacological consequences in intact tissues. In addition to the concerns raised in the beginning of this section, it can be pointed out that many studies that demonstrate functional interactions between receptors were performed at low levels of GTP (significantly lower than $1 \mathrm{mM}$, normally present in intact cells). Under such circumstances, G proteins can become limiting, and unphysiological receptorreceptor interactions may occur (Chabre et al., 2009). In a dimeric complex, both receptors may not always (or even rarely) be simultaneously active and signaling (Rovira et al., 2010). This implies that the signaling consequences can be very complex. Multiple interactions can potentially occur in a given cell. It is unclear which rules determine how partnerships are formed. Thus, the fact that adenosine receptors can form multimeric complexes of different sorts will necessitate much more work on signaling in intact cells in vivo. 


\section{Receptor Polymorphisms and Disease Susceptibility}

Among the many natural receptor variants possible, only single-nucleotide polymorphisms (SNPs) have been reported for adenosine receptors. SNPs in the $A_{1}$ and $\mathrm{A}_{2 \mathrm{~A}} \mathrm{R}$ only have been associated with disease susceptibility. Significant differences were noted between healthy persons and patients with aspirin-intolerant asthma (AIA) in ADORA1 SNP genotype frequencies for $1405 \mathrm{C}>\mathrm{T}(P=0.001)$ and $\mathrm{A} 102 \mathrm{~A}(P=0.013)$. In the haplotype analysis, ht[C-T-G] $(P=0.003)$ and ht[A-C-G] $(P=0.032)$ in ADORA1 and ht[A-T] in ADORA2A $(P=0.013)$ were significantly associated with AIA. These findings suggest that adenosine might play a role in the development of AIA through interactions with the $\mathrm{A}_{1}$ and $\mathrm{A}_{2 \mathrm{~A}}$ receptors (Kim et al., 2009a).

Other variants in the 3 '-untranslated region of the ADORA1 gene were associated with changes in infarct size in patients with ischemic cardiomyopathy (Tang et al., 2007). DNA samples from 273 subjects with ischemic cardiomyopathy and 203 healthy control subjects were screened, revealing that three variants (nt 1689 C/A, nt 2206 Tdel, nt 2683del36) were linked to changes in infarct size. The first two variants were associated with a decrease in infarct size, the latter with an increase. All three disease-associated variants were predicted to alter mRNA secondary structure, suggesting these variants have functional significance. The authors also addressed the limitation of such association studies. First, the occurrence of the three variants mentioned above was relatively rare. Second, the selection of patients introduced some bias. The group of patients in this study had survived a myocardial infarction, which may have enriched the population of those who had the wild-type phenotype, whereas the entry requirement of an ejection fraction $\leq 35 \%$ in this study might have biased the data by excluding those with small infarcts. In addition, some of the patients in the group with coronary artery disease might have had multiple infarctions, leading to larger infarct sizes.

Data from clinical and behavioral pharmacological studies have also implicated adenosine receptors in anxiety behaviors. Subjects from 70 panic disorder pedigrees and 83 child-parent "trios" were genotyped at five SNPs in and near the ADORA2A gene and were analyzed for genetic linkage and association. Linkage analysis revealed elevated logarithm of odds scores for a silent substitution $(1083 \mathrm{C} / \mathrm{T}=1976 \mathrm{C}>\mathrm{T}, \mathrm{SNP}-4)$ in the second coding exon. Analyses carried out by broadening the panic disorder phenotype to include agoraphobia continued to support linkage to ADORA2A. These findings provide evidence for a susceptibility locus for panic disorder, possibly including agoraphobia, either within the ADORA2A gene or in a nearby region of chromosome
22. (Hamilton et al., 2004). Alsene et al. (2003) and Childs et al. (2008) found a significant association between self-reported anxiety after caffeine administration and a number of polymorphisms on the $\mathrm{A}_{2 \mathrm{~A}}$ receptor gene, among others the known $1976 \mathrm{C}>\mathrm{T}$ and the new $2592 \mathrm{C}>$ Tins polymorphisms. In both genotypes, greater increases in anxiety after caffeine administration were reported. These studies show that an adenosine receptor gene polymorphism that had been associated with panic disorder before (Deckert et al., 1998) is also linked to anxiogenic responses to caffeine. There is also an association between adenosine levels ( Rétey et al., 2005) and adenosine $\mathrm{A}_{2 \mathrm{~A}}$ receptors (Rétey et al., 2007) and sleep. Thus, there exist genetic associations between adenosine deaminase and deep sleep and between variants in the $\mathrm{A}_{2 \mathrm{~A}}$ receptor and the effects of caffeine on sleep and anxiety (Rétey et al., 2005, 2007). Hohoff et al. (2010) studied the $1976 \mathrm{C}>\mathrm{T}$ polymorphism and other potentially functionally relevant variants in subjects with Parkinson's disease or anxiety traits. The results support an important role of $\mathrm{A}_{2 \mathrm{~A}} \mathrm{R}$ variants in the pathogenesis of anxiety disorders, suggesting their use as vulnerability factors for increased susceptibility to these conditions.

Five SNPs within ADORA2A were associated with stopping methotrexate therapy as a result of adverse events in patients with rheumatoid arthritis. Analysis by adverse event type showed that the association was specific for gastrointestinal toxicity. No association was observed between ADORA2A and efficacy outcomes. Knowledge of the ADORA2A genotype may help to improve identification of patients at high risk of gastrointestinal toxicity with methotrexate (Hider et al., 2008).

High adenosine plasma levels and high expression of adenosine $\mathrm{A}_{2 \mathrm{~A}}$ receptors are observed in patients with unexplained syncope and a positive head-up tilt test. The most common SNP in the $A_{2 A} R$ gene is c.1364 T $>C$. Patients with a CC genotype had a higher incidence of spontaneous syncopal episodes (Saadjian et al., 2009).

\section{Genetically Modified Animals}

In the previous review on adenosine receptors in this journal, we presented initial information on mice lacking $\mathrm{A}_{2 \mathrm{~A}}, \mathrm{~A}_{1}$, and $\mathrm{A}_{3}$ receptors (Ledent et al., 1997; Chen et al., 1999; Salvatore et al., 2000; Johansson et al., 2001; Sun et al., 2001). Since then, $A_{2 B}$ knockout mice (Yang et al., 2006; Hua et al., 2007b), several mice that allow tissue-specific targeting (Scammell et al., 2003; Bastia et al., 2005; Huang et al., 2006), and double knockouts have been described (Yang et al., 2009a). In addition, several mice that are deficient in the enzymes that form or degrade adenosine have been used to characterize the physiological significance of the receptors. There have also been reports on the use of small interfering RNA constructs (Popescu and Popescu, 2007). These animal models are briefly presented in Table 1 as 
well as in several reviews, including Fredholm et al., 2005; Yaar et al., 2005; Jacobson, 2009.

Here we provide a brief summary of key events in the history of adenosine receptor cloning, global deletion, and targeted deletion that led to important new insights about receptor function. The first adenosine receptors to be cloned were the canine $A_{1}$ and $A_{2 A}$ receptors, identified on the basis of homology to previously cloned GPCRs (Maenhaut et al., 1990; Libert et al., 1991). This was followed by identification of the $A_{2 B} R$ gene (Rivkees and Reppert, 1992) and the $A_{3} R$ gene (Zhou et al., 1992).

\section{A. $A_{1} R$}

Targeted disruption of the $A_{1} A R$ gene resulted in mice that gained weight normally and had normal heart rate, blood pressure, and body temperature but showed signs of increased anxiety (Johansson et al., 2001). Electrophysiological recordings from hippocampal slices revealed that adenosine-mediated inhibition of excitatory glutamatergic neurotransmission was abolished and the analgesic effect of intrathecal adenosine was lost. The decrease in neuronal activity upon hypoxia was reduced. These experiments established the importance of the $\mathrm{A}_{1} \mathrm{R}$ under pathophysiological conditions including painful stimulation and hypoxia.

\section{B. $A_{2 A} R$}

The $\mathrm{A}_{2 \mathrm{~A}} \mathrm{R}$ was the first to be deleted. This was accomplished using the mouse CD1 strain (Ledent et al., 1997). In $A_{2 A} R(-/-)$ mice, caffeine, which normally stimulates exploratory behavior, became a depressant. Knockout animals scored higher in anxiety tests, and male mice were much more aggressive toward intruders. Blood pressure, heart rate, and platelet aggregation were all increased. The agonist CGS-21680 lost its pharmacological activity. A second $\mathrm{A}_{2 \mathrm{~A}} \mathrm{R}(-/-) \mathrm{C} 57 \mathrm{BL} / 6$ line was used to demonstrate deleterious effects of adenosine signaling in the brain. Although adenosine production generally protects tissues from injury, Chen et al. (1999) demonstrated that mice lacking the $\mathrm{A}_{2 \mathrm{~A}} \mathrm{R}$ had reduced brain infarction in response to occlusion of the middle cerebral artery. This C57BL/6 $\mathrm{A}_{2 \mathrm{~A}} \mathrm{R}(-/-)$ mouse was also used to address a controversial aspect of $A_{2 A} R$ signaling. In the striatum, the $\mathrm{A}_{2 \mathrm{~A}} \mathrm{R}$ is largely coexpressed with dopamine D2 receptors, where it modulates dopaminergic activity. These and other findings led to suggestions that heterodimers might be required for receptor function. However, mice deficient in $\mathrm{A}_{2 \mathrm{~A}} \mathrm{Rs}$ or $\mathrm{D}_{2} \mathrm{Rs}$ revealed that either receptor can elicit behavioral and biochemical activity in the absence of the other (Chen et al., 2001). The $\mathrm{A}_{2 \mathrm{~A}} \mathrm{R}$ deletion has also been moved onto a $\mathrm{Balb} / \mathrm{C}$ genetic background and deposited at the Jackson Laboratory (C;129S-Adora2a $a^{\text {tm1Jfc } / J ; ~ B a r ~ H a r b o r, ~ M E) . ~}$

A targeting vector to insert loxP sites flanking the first coding exon of the $A_{2 A} R$ gene was created. This floxed construct was electroporated into (129X1/
SvJX129S1/Sv)F1-Kitl ${ }^{+}$derived R1 embryonic stem cells. Correctly targeted embryonic stem cells were injected into recipient blastocysts. Resulting chimeric male animals were back-crossed to wild-type C57BL/6J mice using a marker-assisted selection. These mice have been used to establish a colony of floxed $\mathrm{A}_{2 \mathrm{~A}} \mathrm{R}$ mice at The Jackson Laboratory (B6;129Adora $\left.2 a^{t m 1 D y j} / \mathrm{J}\right)$. A2a(flox/flox $) \times$ LysM-cre mice were used to demonstrate a role for granulocyte $\mathrm{A}_{2 \mathrm{~A}} \mathrm{R}$ signaling in a model of lipopolysaccharide (LPS)-induced lung injury (Reutershan et al., 2007). Targeted $A_{2 A} R$ deletion reversed the ability of an $\mathrm{A}_{2 \mathrm{~A}} \mathrm{R}$ agonist to inhibit LPS-induced neutrophil recruitment, cytokine release, and vascular leak. To investigate central $A_{2 A} R$ signaling, mice with a floxed $A_{2 A} R$ were crossed with CaMKII $\alpha$-Cre mice to delete $\mathrm{A}_{2 \mathrm{~A}} \mathrm{Rs}$ in both striatal neurons and other forebrain structures (Bastia et al., 2005), or Dlx5/6-Cre mice to selectively delete $\mathrm{A}_{2 \mathrm{~A}} \mathrm{Rs}$ in the striatum (Shen et al., 2008). Cocaineand phencyclidine-induced psychomotor activities were enhanced when striatal receptors were selectively deleted, but attenuated when receptors were more globally deleted. These results indicate that $\mathrm{A}_{2 \mathrm{~A}} \mathrm{Rs}$ in striatal and extrastriatal neurons exert opposing modulation of psychostimulant effects.

\section{C. $A_{2 B} R$}

$\mathrm{A}_{2 \mathrm{~B}} \mathrm{R}(-/-)$ mice also containing a $\beta$-galactosidase knockin were produced by Yang et al. (2006). These mice displayed moderate inflammation as a result of elevated basal plasma tumor necrosis factor- $\alpha$ and an exaggerated response to LPS challenge. Based on $\beta$-galactosidase expression, these mice were also used to demonstrate high expression of $\mathrm{A}_{2 \mathrm{~B}} \mathrm{Rs}$ on type II alveolar epithelial cells in the lung (Cagnina et al., 2009). NECAstimulated interleukin-6 production detected in macrophages from wild-type mice was absent in another line of $\mathrm{A}_{2 \mathrm{~B}} \mathrm{R}(-/-)$ mice prepared by Deltagen (San Mateo, CA). Thus, $\mathrm{A}_{2 \mathrm{~B}} \mathrm{R}$ signaling has both pro- and anti-inflammatory elements. The $\mathrm{A}_{2 \mathrm{~B}} \mathrm{R}(-/-)$ mice produced by Deltagen along with mice lacking the other adenosine receptor subtypes were used to determine which adenosine receptor subtype is most responsible for eliciting myocardial preconditioning (Eckle et al., 2007). The results suggest a major contribution by $\mathrm{A}_{2 \mathrm{~B}} \mathrm{R}$ signaling.

\section{D. $A_{3} R$}

Mice with targeted disruption of the $\mathrm{A}_{3} \mathrm{R}$ differed from wild-type mice in failing to enhance antigen-stimulated mast cell degranulation in response to Cl-IB-MECA (Salvatore et al., 2000). It is notable, however, that functional $\mathrm{A}_{3} \mathrm{Rs}$ seem to be absent from human mast cells. $\mathrm{A}_{3} \mathrm{R}$ deletion was initially reported to protect the heart from ischemic injury (Guo et al., 2001), possibly by reducing myocardial mast cell degranulation in the mouse (Rork et al., 2008). However, a recent study using con- 
genic (C57BL/6) A3R(-/-) mice revealed a cardioprotective effect of A3AR activation (Ge et al., 2006).

\section{E. Adenosine Production}

The generation of mice with deletions in CD39 and CD73, ecto-enzymes involved in adenine nucleotide metabolism, have altered the prevailing view of the predominant pathways of extracellular adenosine production. Although ADP enhances and adenosine inhibits platelet aggregation, deletion of CD39 caused prolonged bleeding times (Enjyoji et al., 1999). This was ascribed to desensitization of platelet P2Y12 receptors as a result of persistently high levels of ADP. Because several other $\mathrm{P} 2$ receptors undergo rapid desensitization, the effects of CD39 deletion on P2-receptor-mediated activities is generally unpredictable because of opposing effects of elevated ATP levels and desensitization of $\mathrm{P} 2$ receptor signaling.

In many instances, the results obtained with receptor-blocking drugs and those observed in the genetically modified animals to determine the roles of the adenosine receptors are entirely consistent. However, this is not always the case. One reason is that the drugs may not be as selective as was thought, and indeed the use of genetically modified animals to test the selectivity of drugs is becoming a more and more established practice. Another reason for discrepancy is that drugs rarely achieve a complete blockade of an adenosine receptor for any length of time and complete elimination of a response and partial blockade may have very different consequences. Therefore, it is of interest that there are some examples in which heterozygous mice can be used to mimic phenotypes of long-term drug treatment (Björklund et al., 2008; Yang et al., 2009b).

A third scenario is that the genetic modification results in major adaptive changes, and there is a common conception that genetic elimination of one of the adenosine receptors should lead to up-regulation of one or more of the other adenosine receptors. There are few, if any, examples of this type of adaptation. Instead, completely different processes may show adaptive changes. However, this also seems generally to occur only rarely and minimally (Johansson et al., 2001, 2007b; Lukashev et al., 2003), but examples of strong adaptive effects also exist (e.g., Teng et al., 2008). Perhaps one should expect only such processes that are physiologically regulated by an adenosine receptor to be compensated for in a targeted receptor deletion. There is little pressure to induce adaptations of processes that occur very rarely during a lifetime. Furthermore, not all physiological processes need to or can be compensated for. It is therefore of some interest that very few examples of adaptive compensations in receptor knockout mice have been noted, but there are numerous examples in which possible adaptations have been insufficiently studied (Table 2).

\section{Receptor Classification: New Drugs}

Selective agonists and antagonists for all four adenosine receptor subtypes are available (Müller, 2000a,b; Yan et al., 2003; Jacobson and Gao, 2006; Müller and Ferré, 2007; Elzein and Zablocki, 2008; Müller and Jacobson, 2011). Affinities of the compounds are listed in Tables 3 and 4, and structures are shown in Figs. 2 to 9. Data from radioligand binding studies are presented; however, in a few cases, only functional data are available. The physiological agonist adenosine (1; bold numerals refer to chemical structures in Tables and Figures) and its close derivatives 2-chloroadenosine (2) and NECA (3) are nonselective; however, they are weaker at $\mathrm{A}_{2 \mathrm{~B}}$ and-with the exception of NECA-also at rat $\mathrm{A}_{3}$ receptors than at the other subtypes (see Table 3). In contrast to adenosine, $\mathbf{2}$ and $\mathbf{3}$ are metabolically quite stable (e.g., toward adenosine deaminase). Note, however, the difficulties of using binding assays to assess the potency of adenosine and the impact of receptor density on agonist potency discussed in section I. $\left[{ }^{3} \mathrm{H}\right] \mathrm{NECA}$ has been used as a radioligand for all four receptor subtypes. We foresee a shift from radioligands to fluorescent ligands for screening in the future (e.g., Kecskés et al., 2010).

A large number of studies over the past 20 years or so have used quite selective receptor agonists and antagonists in a variety of biological systems. It is beyond the scope of an update on receptor nomenclature and classification to review this vast literature. A recent volume in the Handbook of Experimental Pharmacology (Wilson and Mustafa, 2009) can provide a convenient inroad to it.

$\mathrm{A}_{1}$-selective adenosine derivatives typically feature a cycloalkyl or an aromatic (phenyl or phenylisopropyl) residue at the exocyclic amino group (compounds 4-14). Some compounds are additionally modified at the $\mathrm{C} 2$ - and/or ribose structure. Selectivity versus $\mathrm{A}_{2 \mathrm{~A}}$ and $\mathrm{A}_{2 \mathrm{~B}}$ is often very high in such $\mathrm{N}^{6}$ derivatives, but some compounds are less selective versus the $\mathrm{A}_{3}$ receptor subtype. If possible, the selectivity should be at least 100-fold for a tool compound used for receptor characterization. $\left[{ }^{3} \mathrm{H}\right](R)-N^{6}$-Phenylisopropyladenosine, $\left[{ }^{3} \mathrm{H}\right] N^{6}$-cyclohexyladenosine, and $\left[{ }^{3} \mathrm{H}\right] 2$-chloro- $N^{6}$-cyclopentyladenosine are used as standard radioligands for $A_{1}$ receptors. Bayer Schering Pharma (Wuppertal, Germany) identified 2-aminodicyanopyridines, such as capadenoson (15), as the first class of non-adenosine-derived, non-nucleoside adenosine receptor agonists (see also Beukers et al., 2004; Chang et al., 2005). Several $A_{1}$ agonists and partial agonists, including $(2 R, 3 S, 4 R, 5 R)$-2-((5-(tert-butyl)-1,3,4-oxadiazol2-yl)methyl)-5-(6-((4-chloro-2-fluorophenyl)amino)-9Hpurin-9-yl)tetrahydrofuran-3,4-diol (GW493838; 5), selodenoson (DTI-0009; 11), $N$-((1S,trans)-2-hydroxycyclopentyl)adenosine (GR79236; 12), tecadenoson (13), (2-\{6[((1R,2R)-2-hydroxycyclopentyl)amino] purin-9-yl $\}(4 S$, $5 S, 2 R, 3 R)-5$-[(2-fluorophenylthio)methyl] oxolane-3,4-diol 
TABLE 2

Selected effects mediated by adenosine via the four adenosine receptors For this table we have predominantly used data from genetically modified organisms.

\begin{tabular}{|c|c|c|c|c|}
\hline Receptor & Effect & $\begin{array}{c}\text { Physiology/ } \\
\text { Pathophysiology }\end{array}$ & $\begin{array}{l}\text { Evidence for } \\
\text { Adaptation }\end{array}$ & Reference \\
\hline \multirow{17}{*}{$\mathrm{A}_{1}$} & Decreased renal blood flow, Tubuloglomerular feedback & Phys & No & Brown et al., 2001; Sun et al., 2001 \\
\hline & Inhibition of lipolysis & Phys & No & Johansson et al., 2008 \\
\hline & Vasoconstriction & $?$ & $?$ & Tawfik et al., 2005; Wang et al., 2010 \\
\hline & Inhibition of neurotransmitter release & Extreme phys & No? & Johansson et al., 2001 \\
\hline & Inhibition of insulin/glucagon release & Phys & No & Johansson et al., 2007a \\
\hline & Reduced heart rate & Phys & No? & Yang et al., 2007 \\
\hline & Osteoclast activation, bone resorption & Phys? & No? & Kara et al., 2010a,b \\
\hline & Sleep & Phys & Yes & $\begin{array}{l}\text { Stenberg et al., 2003; Oishi et al., } \\
2008\end{array}$ \\
\hline & & & & Goldman et al. 2010 \\
\hline & Acupuncture & Extreme phys? & $?$ & \\
\hline & Prevention of epilepsy & Path & $?$ & $\begin{array}{l}\text { Fedele et al. 2006; Li et al. 2007; } \\
\text { Kochanek et al } 2006\end{array}$ \\
\hline & & & & Hua et al., 2007a \\
\hline & Bronchoconstriction & Path & $?$ & \\
\hline & Analgesia & Extreme phys & No & $\begin{array}{l}\text { Johansson et al., 2001; Wu et al., } \\
2005\end{array}$ \\
\hline & Preconditioning & Path & No & $\begin{array}{l}\text { Schulte et al., 2004; Lankford et al., } \\
\quad 2006\end{array}$ \\
\hline & & & & Wendler et al. 2007 \\
\hline & Tolerance to hypoxia & Path & No? & \\
\hline \multirow[t]{7}{*}{$\mathrm{A}_{2 \mathrm{~A}}$} & Wakefulness, locomotion & Phys & No & $\begin{array}{l}\text { Ledent et al., 1997; El Yacoubi et al., } \\
\text { 2000; Chen et al., 2000; Huang et } \\
\text { al., } 2005\end{array}$ \\
\hline & $\begin{array}{l}\text { Neurodegeneration (including Parkinson's disease and } \\
\text { Alzheimer's disease) }\end{array}$ & Path & No & Chen et al., 1999, 2001b, 2007 \\
\hline & Immunosuppression & Extreme/Path & No? & $\begin{array}{l}\text { Ohta and Sitkovsky, 2001; Lappas et } \\
\text { al., 2005; Ohta et al., } 2007\end{array}$ \\
\hline & Vasodilatation/hypotension & Phys/Extreme & No? & Ledent et al., 1997 \\
\hline & Coronary vasodilatation & Phys/Extreme & Yes? & Morrison et al., 2002 \\
\hline & Inhibition of platelet aggregation & Extreme & No? & Ledent et al., 1997 \\
\hline & Angiogenesis & Extreme & No? & Montesinos et al., 2002 \\
\hline \multirow[t]{2}{*}{$\mathrm{A}_{2 \mathrm{~B}}$} & Vascular integrity & Phys/Extreme & No & Yang et al., 2006, 2008 \\
\hline & Preconditioning & Extreme & No & Eckle et al., 2007 \\
\hline \multirow[t]{4}{*}{$\mathrm{A}_{3}$} & Increased mast cell activation & Extreme/Path & No? & $\begin{array}{l}\text { Salvatore et al., 2000; Tilley et al., } \\
2000\end{array}$ \\
\hline & Airway contraction & Path & No? & Hua et al., 2008 \\
\hline & Inflammatory pain & Extreme/Path & No? & Wu et al., 2002 \\
\hline & White cell chemotaxis & Extreme/Path & No? & Chen et al., 2006 \\
\hline
\end{tabular}

(GS9667/CVT-3619; 14), and capadenoson (BAY 68-4986; 15) have been or are currently being evaluated in clinical trials for various indications (see section VIII).

$\mathrm{A}_{2 \mathrm{~A}}$-selective agonists have been developed by introducing bulky substituents in the 2-position of the adenosine scaffold (compounds 16-22). CGS-21680 (16) has been widely used for studying $A_{2 A}$ receptor activation and is used as a standard $\mathrm{A}_{2 \mathrm{~A}}$ radioligand in its tritium-labeled form. It is $\mathrm{A}_{2 \mathrm{~A}}$-selective in rat but shows relatively high affinity for the human $\mathrm{A}_{3}$ receptor and thus low selectivity for the human $\mathrm{A}_{2 \mathrm{~A}}$ subtype (Table 3). Regadenoson (22; Lexiscan, CVT 3146) is clinically used as a diagnostic agent for pharmacological stress testing because of its vasodilatory effects. Apadenoson (ATL-146e; 17) is being developed for the same purpose. Several other $\mathrm{A}_{2 \mathrm{~A}}$-selective agonists are being or have been clinically evaluated, including UK-432097 (19), sonedenoson (MRE-0094; 20), and binodenoson (WRC-0470; 21).

Because adenosine analogs generally have a low affinity at $\mathrm{A}_{2 \mathrm{~B}}$ receptors, it has been much harder to develop agonists with selectivity for the $A_{2 B}$ than for the other receptor subtypes. Only two $\mathrm{A}_{2 \mathrm{~B}}$-selective agonists have been developed so far, the adenosine derivative $\mathbf{2 3}$ and the 2-aminodicyanopyridine derivative 2-[6-amino-3,5-dicyano-4-[4-(cyclopropylmethoxy) phenyl]pyridin-2-ylsulfanyl] acetamide (BAY 60-6583; 24). Both compounds have yet to be broadly characterized. A selective agonist radioligand for $\mathrm{A}_{2 \mathrm{~B}}$ receptors is currently not available.

The development of $\mathrm{A}_{3}$-selective agonists has been quite successful by optimizing the substitution pattern of the adenosine scaffold in the $\mathrm{N}^{6}$, the $\mathrm{C} 2$, and the $5^{\prime}$ positions. In the most selective compounds, the ribose moiety is replaced by a bicycloalkyl ring structure (30, 31). The standard $A_{3}$ agonists are IB-MECA (25) and Cl-IB-MECA (26), the 2-Cl analog 26 being more selective versus $A_{1}$ receptors than $\mathbf{2 5}$. Several $A_{3}$ agonists are undergoing clinical trials $(\mathbf{2 5}, \mathbf{2 6}, \mathbf{2 7}, \mathbf{3 0})$. Iodinated agonist radioligands are frequently used for labeling $\mathrm{A}_{3}$ receptors, but recently, the first ${ }^{3} \mathrm{H}$-labeled compound, $\left[{ }^{3} \mathrm{H}\right] 2$-(1-hexynyl)- $N$-methyladenosine (28), has been developed.

The classic nonselective adenosine receptor antagonists are the xanthine derivatives caffeine (32) and theophylline (33), both of which are used therapeutically. Compared with many of the synthetic alkylxanthines, they are only 
TABLE 3

Most data for $\mathrm{A}_{2 \mathrm{~B}}$ are from functional studies.

\begin{tabular}{|c|c|c|c|c|c|}
\hline & & \multicolumn{4}{|c|}{$K_{i}$} \\
\hline & & $\mathrm{A}_{1}$ & $\mathrm{~A}_{2 \mathrm{~A}}$ & $\mathrm{~A}_{2 \mathrm{~B}}$ & $\mathrm{~A}_{3}$ \\
\hline & & & & & \\
\hline \multicolumn{6}{|c|}{ Nonselective agonists } \\
\hline \multirow[t]{2}{*}{1} & Adenosine $^{a}$ & $\sim 100(\mathrm{~h})^{b}$ & $310(\mathrm{~h})^{b}$ & $15,000(\mathrm{~h})^{b}$ & $290(\mathrm{~h})^{b}$ \\
\hline & & $73(\mathrm{r})^{b}$ & $150(\mathrm{r})^{b}$ & $5100(\mathrm{r})^{b}$ & $6500(\mathrm{r})^{b}$ \\
\hline 2 & 2-Chloro-adenosine & $6.7(\mathrm{r})^{c}$ & $76(\mathrm{r})^{c}$ & $24,000(\mathrm{~h})^{d}$ & $1890(\mathrm{r})^{e}$ \\
\hline \multirow[t]{2}{*}{3} & NECA & $14(\mathrm{~h})^{b}$ & $20(\mathrm{~h})^{b}$ & $140(\mathrm{~h})^{b}$ & $25(\mathrm{~h})^{b}$ \\
\hline & & $5.1(\mathrm{r})^{f}$ & $9.7(\mathrm{r})^{f}$ & $\begin{array}{l}1890(\mathrm{~h})^{g} \\
1900(\mathrm{~m})^{f}\end{array}$ & $113(\mathrm{r})^{f}$ \\
\hline \multicolumn{6}{|c|}{$\mathrm{A}_{1}$-selective agonists } \\
\hline \multirow[t]{2}{*}{4} & $R$-PIA & $2.04(\mathrm{~h})^{h}$ & $220(\mathrm{r})^{c}$ & $150,000(\mathrm{~h})^{d}$ & $33(\mathrm{~h})^{i}$ \\
\hline & & $1.2(\mathrm{r})^{c}$ & & $19,000(\mathrm{~m})^{j}$ & $158(\mathrm{r})^{e}$ \\
\hline 5 & GW493838 & N.D. & N.D. & N.D. & N.D. \\
\hline \multirow[t]{2}{*}{6} & CHA & $0.85(\mathrm{r})^{c}$ & $460(\mathrm{r})^{c}$ & $160,000(\mathrm{~h})^{d}$ & $1025(\mathrm{~h})^{k}$ \\
\hline & $\mathrm{CPA}$ & $2.3(\mathrm{~h})^{l}$ & $794(\mathrm{~h})^{l}$ & $18,600(\mathrm{~h})^{l}$ & $\begin{array}{l}176(\mathrm{r})^{e} \\
72(\mathrm{~h})^{l}\end{array}$ \\
\hline \multirow[t]{3}{*}{8} & CCPA & $0.83(\mathrm{~h})^{l}$ & $2270(\mathrm{~h})^{l}$ & $18,800(\mathrm{~h})^{l}$ & $38(\mathrm{~h})^{l}$ \\
\hline & & $1.3(\mathrm{r})^{m}$ & $950(\mathrm{r})^{m}$ & & $237(\mathrm{r})^{m}$ \\
\hline & & $0.1(\mathrm{rb})^{m}$ & & & $37.7(\mathrm{rb})^{m}$ \\
\hline 9 & TCPA & $2.8(\mathrm{~h})^{n}$ & $210(\mathrm{~h})^{n}$ & $>10,000(\mathrm{~h})^{n}$ & $600(\mathrm{~h})^{n}$ \\
\hline 10 & $2^{\prime}-\mathrm{Me}-\mathrm{CCPA}$ & $1.8(\mathrm{c})^{\circ}$ & $3900(\mathrm{c})^{\circ}$ & N.D. & $5000(r)^{\circ}$ \\
\hline 11 & Selodenoson (DTI-0009) & N.D. & N.D. & N.D. & N.D. \\
\hline 12 & GR79236 & $3.1(\mathrm{r})^{l}$ & $1300(\mathrm{~h})^{l}$ & N.D. & N.D. \\
\hline 13 & Tecadenoson & $6.5(\mathrm{p})^{l}$ & $2315(\mathrm{~h})^{l}$ & N.D. & N.D. \\
\hline 14 & GS9667 (CVT-3619) & $55(\mathrm{~h})^{p}$ & $>10,000(\mathrm{~h})^{p}$ & $>50,000(\mathrm{~h})^{p}$ & $>1000(\mathrm{~h})^{p}$ \\
\hline 15 & Capadenoson (BAY 68-4986) & N.D. & N.D. & N.D. & N.D. \\
\hline \multicolumn{6}{|c|}{$\mathrm{A}_{2 \mathrm{~A}}$-selective agonists } \\
\hline \multirow[t]{3}{*}{16} & CGS21680 & $289(\mathrm{~h})^{l}$ & $27(\mathrm{~h})^{l}$ & $>10,000(\mathrm{~h})^{l}$ & $67(\mathrm{~h})^{l}$ \\
\hline & & $1800(\mathrm{r})^{m}$ & $19(\mathrm{r})^{m}$ & $>10,000(\mathrm{r})^{m}$ & $584(\mathrm{r})^{m}$ \\
\hline & & $120(\mathrm{rb})^{m}$ & & & $673(\mathrm{rb})^{m}$ \\
\hline 17 & Apadenoson (ATL-146e) & $77(\mathrm{~h})^{l}$ & $0.5(\mathrm{~h})^{l}$ & N.D. & $45(\mathrm{~h})^{l}$ \\
\hline 18 & ATL-313 & N.D. & N.D. & N.D. & N.D. \\
\hline 19 & UK-432097 & N.D. & $4(\mathrm{~h})$ & N.D. & N.D. \\
\hline 20 & Sonedenoson (MRE-0094) & N.D. & N.D. & N.D. & N.D. \\
\hline 21 & Binodenoson (WRC-0470) & $48,000(\mathrm{~h})^{l}$ & $270(\mathrm{~h})^{l}$ & $430,000(\mathrm{~h})^{l}$ & $903(\mathrm{~h})^{l}$ \\
\hline 22 & Regadenoson (CV-3146) & $>10,000(\mathrm{~h})^{l}$ & $290(\mathrm{~h})^{l}$ & $>10,000(\mathrm{~h})^{l}$ & $>10,000(\mathrm{~h})^{l}$ \\
\hline \multicolumn{6}{|c|}{$\mathrm{A}_{2 \mathrm{~B}}$-selective agonists } \\
\hline 23 & $\mathrm{~A}_{2 \mathrm{~B}}$ agonist & $1050(\mathrm{~h})^{q}$ & $1550(\mathrm{~h})^{q}$ & $82(\mathrm{~h})^{q}$ & $>5000(\mathrm{~h})^{q}$ \\
\hline \multirow[t]{4}{*}{24} & BAY 60-6583 & $>10,000(\mathrm{~h})^{a, r}$ & $>10,000(\mathrm{~h})^{a, r}$ & $3-10(\mathrm{~h})^{r}$ & $>10,000(\mathrm{~h})^{a, r}$ \\
\hline & & & & $330(\mathrm{~m})^{s}$ & \\
\hline & & & & $750(\mathrm{~d})^{s}$ & \\
\hline & & & & $340(\mathrm{rb})^{s}$ & \\
\hline \multicolumn{6}{|c|}{$\mathrm{A}_{3}$-selective agonist } \\
\hline 25 & IB-MECA (CF101) & $51(\mathrm{~h})^{l}$ & $2900(\mathrm{~h})^{l}$ & $11,000(\mathrm{~h})^{l}$ & $1.8(\mathrm{~h})^{l}$ \\
\hline \multirow[t]{3}{*}{26} & Cl-IB-MECA & $220(\mathrm{~h})^{l}$ & $5360(\mathrm{~h})^{l}$ & $>10,000(\mathrm{~h})^{m}$ & $1.4(\mathrm{~h})^{l}$ \\
\hline & CF102 & $280(\mathrm{r})^{m}$ & $470(\mathrm{r})^{m}$ & $>10,000(\mathrm{~m})^{m}$ & $0.33(\mathrm{r})^{m}$ \\
\hline & & $35(\mathrm{~m})^{m}$ & $\sim 10,000(\mathrm{~m})^{m}$ & & $0.18(\mathrm{~m})^{m}$ \\
\hline \multirow[t]{2}{*}{27} & CP608,039 & $7300(\mathrm{~h})^{t}$ & N.D. & N.D. & $5.8(\mathrm{~h})^{t}$ \\
\hline & & $1750(\mathrm{rb})^{t}$ & & & $83(\mathrm{rb})^{t}$ \\
\hline 28 & HEMADO & $330(\mathrm{~h})^{u}$ & $1200(\mathrm{~h})^{u}$ & $>30,000(\mathrm{~h})^{u}$ & $1.10(\mathrm{~h})^{u}$ \\
\hline 29 & 2-Phenylethynyl-adenosine derivative & $32,800(\mathrm{~h})^{v}$ & $41,700(\mathrm{~h})^{v}$ & $>30,000(\mathrm{~h})^{v}$ & $0.44(\mathrm{~h})^{v}$ \\
\hline \multirow[t]{3}{*}{30} & MRS3558 (CF502) & $260(\mathrm{~h})^{l}$ & $2330(\mathrm{~h})^{l}$ & $>10,000(\mathrm{~h})^{l}$ & $0.29(\mathrm{~h})^{l}$ \\
\hline & & $105(\mathrm{r})^{m}$ & $1080(\mathrm{r})^{m}$ & & $1.0(\mathrm{r})^{m}$ \\
\hline & & $15.8(\mathrm{~m})^{m}$ & $10,400(\mathrm{~m})^{m}$ & & $1.49(\mathrm{~m})^{m}$ \\
\hline \multirow[t]{2}{*}{31} & MRS5151 & $14,900(\mathrm{~h})^{w}$ & $\sim 10,000(\mathrm{~h})^{w}$ & N.D. & $2.38(\mathrm{~h})^{w}$ \\
\hline & & $10,500(\mathrm{~m})^{w}$ & $>10,000(\mathrm{~m})^{w}$ & & $24.4(\mathrm{~m})^{w}$ \\
\hline
\end{tabular}

h, human; c, cow; d, dog; m, mouse; p, pig; r, rat; rb, rabbit; $R$-PIA, $(R)$ - $N^{6}$-phenylisopropyladenosine; N.D., no data available; CHA, $N^{6}$-cyclohexyladenosine; CCPA, 2-chloro-

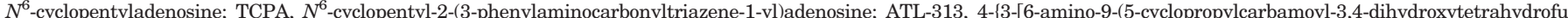

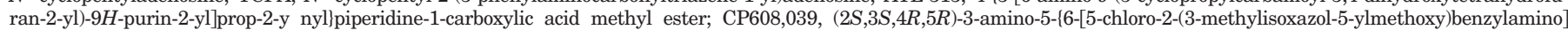

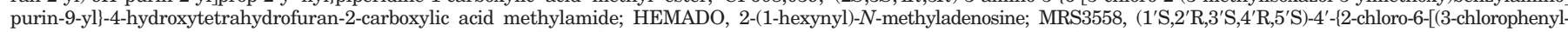

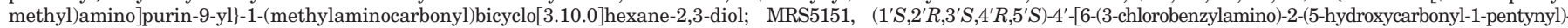
9-yl]-2',3'-dihydroxybicyclo[3.10.0]hexane-1'-carboxylic acid $N$-methylamide.

${ }^{a}$ Data are from functional studies.

${ }^{b}$ Yan et al., 2003.

${ }^{c}$ Daly et al., 1993

${ }^{d}$ Bruns, 1980 .

${ }^{e}$ van Galen et al., 1994.

${ }^{f}$ Müller and Stein, 1996.

${ }^{g}$ Data from radioligand binding studies versus the antagonist radioligand $\left[{ }^{3}\right.$ H]PSB-603 (S. Hinz and C. E. Müller, unpublished data).

${ }^{h}$ Klotz et al., 1998.

${ }^{i}$ Salvatore et al., 1993.

${ }^{j}$ Brackett and Daly, 1994

${ }^{k}$ Sajjadi et al., 1996.

${ }^{l}$ Jacobson and Gao, 2006.

${ }^{m}$ Liang et al., 2010.

${ }^{n}$ Beukers et al., 2003

${ }^{\circ}$ Franchetti et al., 1998

\footnotetext{
${ }^{p}$ Elzein and Zablocki, 2008.

${ }^{q}$ Baraldi et al., 2007.

${ }^{r}$ Kuno et al., 2007.

${ }^{s}$ Data from radioligand binding studies versus the antagonist radioligand $\left[{ }^{3} \mathrm{H}\right] \mathrm{MRS} 1754$ (Auchampach et al., 2009).

${ }^{t}$ Tracey et al., 2003.

${ }^{u}$ Volpini et al., 2002; Klotz et al., 2007.

${ }^{v}$ Volpini et al., 2009.

${ }^{w}$ Melman et al., 2008
} 
TABLE 4

Adenosine receptor affinities of antagonists

A few $\mathrm{A}_{2 \mathrm{~B}}$ data are from functional (cAMP) studies.

\begin{tabular}{llll}
\multicolumn{5}{c}{$K_{\mathrm{i}}$} \\
\hline $\mathrm{A}_{1}$ & $\mathrm{~A}_{2 \mathrm{~A}}$ & $\mathrm{~A}_{2 \mathrm{~B}}$ & $\mathrm{~A}_{3}$ \\
& $n M$ & &
\end{tabular}

Nonselective antagonists 32

33

34

$\mathrm{A}_{1}$-selective antagonists 35

36

37

38

39

$$
40
$$

42

$\mathrm{A}_{2 \mathrm{~A}}$-selective antagonists 43

\section{45$$
\begin{aligned}
& 46 \\
& 47 \\
& 48 \\
& 49 \\
& 50 \\
& 51 \\
& 52
\end{aligned}
$$

$\mathrm{A}_{2 \mathrm{~B}}$-selective antagonists 53
Caffeine

Theophylline

CGS15943

DPCPX (CPX)

CPFPX

Rolofylline (KW-3902, NAX)

PSB-36

Toponafylline (BG-9928)

FK-453

SLV320

\section{LUF5981}

Istradefylline (KW6002)

$\mathrm{CSC}\left(K_{\mathrm{i}} \mathrm{MAO}-\mathrm{B}=80.6 \mathrm{nM}\right)^{g g}$ MSX-2

SYN-115

BIIB014 (V2006)

ZM-241385

ST-1535

SCH-58261

Preladenant (SCH-420814)

SCH- 442416

MRS1754

$10,700(\mathrm{~h})^{a}$
$44,900(\mathrm{~h})^{b}$
$41,000(\mathrm{r})^{f}$
$44,000(\mathrm{r})^{g}$
$47,000(\mathrm{gp})^{k}$
$44,000(\mathrm{c})^{k}$
$6770(\mathrm{~h})^{l}$
$14,000(\mathrm{r})^{m}$
$8740(\mathrm{r})^{a}$
$7060(\mathrm{gp})^{o}$
$4710(\mathrm{rb})^{o}$
$9050(\mathrm{~s})^{o}$
$6330(\mathrm{c})^{o}$
$3.5(\mathrm{~h})^{s}$

$6.4(\mathrm{r})^{s}$

$3.0(\mathrm{~h})^{t}$

$0.50(\mathrm{r})^{t}$

$1.0(\mathrm{r})^{d}$

$0.18(\mathrm{r})^{\circ}$

$1.06(\mathrm{gp})^{\circ}$

$3.9(\mathrm{gp})^{k}$

$0.21(\mathrm{rb})^{\circ}$

$0.10(\mathrm{~s})^{\circ}$

$0.05(\mathrm{c})^{\circ}$

$0.29(\mathrm{c})^{k}$

$11.4(\mathrm{~d})^{r}$

$1.26(\mathrm{~h})^{v}$

$0.63(\mathrm{r})^{v}$

$1.37(\mathrm{p})^{v}$

$0.18(\mathrm{c})^{v}$

$0.72(\mathrm{~h})^{w}$

$8.0(\mathrm{~h})^{x}$

$0.19(\mathrm{r})^{y}$

$12.6(\mathrm{r})^{w}$

$0.7(\mathrm{~h})^{t}$

$0.124(\mathrm{r})^{t}$

$7.4(\mathrm{~h})^{x}$

$3.9(\mathrm{mk})^{z}$

$1.3(\mathrm{r})^{x}$

$29(\mathrm{~d})^{z}$

$18(\mathrm{~h})^{a a}$

$1.00(\mathrm{~h})^{b b}$

$2.51(\mathrm{r})^{b b}$

$0.90(\mathrm{~h})^{c c}$

$841(\mathrm{~h})^{d d}$

$230(\mathrm{r})^{d d}$

$28,000(\mathrm{r})^{h h}$

$900(\mathrm{r})^{i j}$

$2500(\mathrm{~h})^{j j}$

68 (h.D.

$774(\mathrm{~h})^{a a}$

$71.8(\mathrm{~h})^{o o}$

$725(\mathrm{~h})^{a a}$

$>1000(\mathrm{~h})^{p p}$

$1110(\mathrm{~h})^{a a}$

$403(\mathrm{~h})^{r r}$ $16.8(\mathrm{r})^{r r}$

\section{$23,400(\mathrm{~h})^{b}$ $9560(\mathrm{~h})^{a}$ \\ $45,000(\mathrm{r})^{g}$ \\ $32,500(\mathrm{r})^{i}$ \\ $48,000(\mathrm{r})^{a}$ \\ $1710(\mathrm{~h})^{l}$ \\ $6700(\mathrm{~h})^{a}$ \\ $22,000(\mathrm{r})^{m}$ \\ $25,300(\mathrm{r})^{a}$}

$1.2(\mathrm{~h})^{s}$

$129(\mathrm{~h})^{l}$

$60(\mathrm{~h})^{t}$

$157(\mathrm{r})^{i}$

$500(\mathrm{r})^{d}$

$940(\mathrm{~h})^{v}$
$812(\mathrm{r})^{v}$

$108(\mathrm{~h})^{w}$

$673(\mathrm{~h})^{x}$

$380(\mathrm{r})^{y}$

$510(\mathrm{r})^{w}$

$980(\mathrm{~h})^{t}$

$552(\mathrm{r})^{t}$

$6410(\mathrm{~h})^{x}$

$943(\mathrm{mk})^{z}$

$2440(\mathrm{r})^{x}$

$4307(\mathrm{~d})^{z}$

$1300(\mathrm{~h})^{a a}$

$398(\mathrm{~h})^{b b}$

$194(\mathrm{~h})^{c c}$

$12(\mathrm{~h})^{e e}$

$91.2(\mathrm{~h})^{d d}$

$2.2(\mathrm{r})^{f f}$

$4.46(\mathrm{r})^{g g}$

$54(\mathrm{r})^{h h}$

$8.04(\mathrm{r})^{i, j j}$

$5.38(\mathrm{~h})^{j j},{ }^{k k}$

$14.5(\mathrm{~h})^{j j}{ }^{m}$

N.D.

$1.3(\mathrm{~h})^{n n}$

$1.6(\mathrm{~h})^{a a}$

$6.6(\mathrm{~h})^{o o}$

$5.0(\mathrm{~h})^{a a}$

$0.9(\mathrm{~h})^{p p}$

$4.1(\mathrm{~h})^{q q}$

$503(\mathrm{~h})^{r r}$ $612(\mathrm{r})^{r r}$ $33,800(\mathrm{~h})$

$10,400(\mathrm{~h})^{d}$

$20,500(\mathrm{~h})^{h}$

$30,000(\mathrm{r})^{j}$

$13,000(\mathrm{~m})^{j}$

$9070(\mathrm{~h})^{d}$

$74,000(\mathrm{~h})^{h} 15,100(\mathrm{r})^{d}$

$5630(\mathrm{~m})^{n}$

$11,000(\mathrm{gp})^{p}$

$17,700(\mathrm{rb})^{n}$

$38,700(\mathrm{~d})^{n}$

$32.4(\mathrm{~h})^{n}$

$9.07(\mathrm{~m})^{n}$

$51(\mathrm{~h})^{t}$

$63.8(\mathrm{~h})^{d}$

$186(\mathrm{r})^{d}$

$200(\mathrm{r})^{p}$

$86.2(\mathrm{~m})^{n}$

$145(\mathrm{gp})^{p}$

$96.0(\mathrm{rb})^{n}$

$147(\mathrm{~d})^{n}$

$132(\mathrm{~d})^{p}$

$\mathrm{nd}^{\mathrm{b}}$

N.D.

$296(\mathrm{~h})^{x}$

$4390(\mathrm{~h})^{x}$

$187(\mathrm{~h})^{t}$

$2300(\mathrm{~h})^{t}$ $6500(\mathrm{r})^{t}$

$90(\mathrm{~h})^{x}$

$>10,000(\mathrm{~h})^{x}$

$980(\mathrm{~h})^{a a}$

$3981(\mathrm{~h})^{b b}$

$501(\mathrm{r})^{b b}$

$>300(\mathrm{~h})^{c c}$

$>10,000(\mathrm{~h})^{d d}$

$4470(\mathrm{~h})^{d d}$

$8200^{i i}$

$>10,000(\mathrm{~h})^{j j}$

$2900(\mathrm{~h})^{l l}$

N.D.

$63(\mathrm{~h})^{n n}$

$75(\mathrm{~h})^{a a}$

$352.3(\mathrm{~h})^{o o}$

$1110(\mathrm{~h})^{a a}$

$>1000(\mathrm{~h})^{p p}$

$>10,000(\mathrm{~h})^{a a}$

$>10,000(\mathrm{~h})^{a a}$

$200(\mathrm{~h})^{b b}$

$637(\mathrm{~h})^{c c}$

$1.97(\mathrm{~h})^{r r}$

$12.8(\mathrm{r})^{r r}$

$16.6(\mathrm{r})^{p}$

$3.39(\mathrm{~m})^{n}$

$9.12(\mathrm{gp})^{p}$

$1.79(\mathrm{rb})^{n}$

$12.8(\mathrm{~d})^{n}$

$12.3(\mathrm{~d})^{p}$
N.D.

$1005(\mathrm{~h})^{n n}$

$743(\mathrm{~h})^{a a}$

$>1000(\mathrm{~h})^{o o}$

$1200(\mathrm{~h})^{a a}$

$>1000(\mathrm{~h})^{p p}$

$>10,000(\mathrm{~h})^{a a}$

$570(\mathrm{~h})^{r r}$ 
TABLE 4-Continued.

\begin{tabular}{|c|c|c|c|c|c|}
\hline & & \multicolumn{4}{|c|}{$K_{\mathrm{i}}$} \\
\hline & & $\mathrm{A}_{1}$ & $\mathrm{~A}_{2 \mathrm{~A}}$ & $\mathrm{~A}_{2 \mathrm{~B}}$ & $\mathrm{~A}_{3}$ \\
\hline & & \multicolumn{4}{|c|}{$n M$} \\
\hline 54 & MRE-2029-F20 & $200(\mathrm{~h})^{s s}$ & $>1000(\mathrm{~h})^{s s}$ & $5.5(\mathrm{~h})^{s s}$ & $>1000(\mathrm{~h})^{s s}$ \\
\hline 55 & PSB-603 & $\begin{array}{l}>10,000(\mathrm{~h})^{t t} \\
>10,000(\mathrm{r})^{t t}\end{array}$ & $\begin{array}{l}>10,000(\mathrm{~h})^{t t} \\
>10,000(\mathrm{r})^{t t}\end{array}$ & $\begin{array}{l}0.553(\mathrm{~h})^{t t} \\
K_{\mathrm{D}} 0.403(\mathrm{~h})^{t t} \\
K_{\mathrm{D}} 0.351(\mathrm{~m})^{t t}\end{array}$ & $>10,000(\mathrm{~h})^{t t}$ \\
\hline 56 & CVT-6883 & $1940(\mathrm{~h})^{u u}$ & $3280(\mathrm{~h})^{u u}$ & $22(\mathrm{~h})^{u u}$ & $1070(\mathrm{~h})^{u u}$ \\
\hline 57 & PSB-1115 & $\begin{array}{l}>10,000(\mathrm{~h})^{u} \\
2200(\mathrm{r})^{m}\end{array}$ & $24,000(\mathrm{r})^{m}$ & $53.4(\mathrm{~h})^{u}$ & $>10,000(\mathrm{~h})^{u}$ \\
\hline 58 & ATL 802 & $\begin{array}{l}369(\mathrm{~h})^{r r} \\
9583(\mathrm{~m})^{r r}\end{array}$ & $\begin{array}{l}654(\mathrm{~h})^{r r} \\
8393(\mathrm{~m})^{r r}\end{array}$ & $\begin{array}{l}2.36(\mathrm{~h})^{r r} \\
8.58(\mathrm{~m})^{r r}\end{array}$ & $\begin{array}{l}>1000(\mathrm{~h})^{r r} \\
>10,000(\mathrm{~m})^{r r}\end{array}$ \\
\hline 59 & LAS38096 & $2821(\mathrm{~h})^{v v}$ & $>1000(\mathrm{~h})^{v v}$ & $17(\mathrm{~h})^{v v}$ & $1043(\mathrm{~h})^{v v}$ \\
\hline $\mathrm{A}_{3}$-se & & & & & \\
\hline 60 & KF26777 & $1800(\mathrm{~h})^{w w}$ & $470(\mathrm{~h})^{w w}$ & $620(\mathrm{~h})^{w w}$ & $0.20(\mathrm{~h})^{w w}$ \\
\hline 61 & PSB-10 & $\begin{array}{l}1700(\mathrm{~h})^{x x} \\
805(\mathrm{r})^{y y}\end{array}$ & $\begin{array}{l}2700(\mathrm{~h})^{x x} \\
6040(\mathrm{r})^{y y}\end{array}$ & N.D. & $0.441(\mathrm{~h})^{y y}$ \\
\hline 62 & PSB-11 & $\begin{array}{l}1640(\mathrm{~h})^{x x} \\
440(\mathrm{r})^{x x}\end{array}$ & $\begin{array}{l}1280(\mathrm{~h})^{x x} \\
2100(\mathrm{r})^{x x}\end{array}$ & $2100(\mathrm{~m})^{y y}$ & $\begin{array}{l}2.34(\mathrm{~h})^{x x} \\
K_{\mathrm{D}} 4.9(\mathrm{~h})^{z z}\end{array}$ \\
\hline 63 & MRE-3008-F20 & $1200(\mathrm{~h})^{a a}$ & $141(\mathrm{~h})^{a a}$ & $2100(\mathrm{~h})^{a a}$ & $0.82(\mathrm{~h})^{a a}$ \\
\hline 64 & MRS1523 & $\begin{array}{l}>10,000(\mathrm{~h})^{a a a} \\
15,600(\mathrm{r})^{a a a}\end{array}$ & $\begin{array}{l}3660(\mathrm{~h})^{a a a} \\
2050(\mathrm{r})^{a a a}\end{array}$ & $\begin{array}{l}>10,000(\mathrm{~h})^{a a a} \\
>10,000(\mathrm{~m})^{a a a}\end{array}$ & $\begin{array}{l}18.9(\mathrm{~h})^{a a} \\
113(\mathrm{r})^{a a a} \\
731(\mathrm{~m})^{a a a}\end{array}$ \\
\hline 65 & MRS1191 & $\begin{array}{l}>10,000(\mathrm{~h})^{a a a} \\
40,100(\mathrm{r})^{a a a}\end{array}$ & $\begin{array}{l}>10,000(\mathrm{~h})^{a a a} \\
>10,000(\mathrm{r})^{a a a}\end{array}$ & $>10,000(\mathrm{~h})^{a a a}$ & $\begin{array}{l}31.4(\mathrm{~h})^{\text {aaa }} \\
1850(\mathrm{r})^{\text {aaa }}\end{array}$ \\
\hline 66 & VUF-5574 & $\leq 10,000(\mathrm{r})^{b b b}$ & $\leq 10,000(\mathrm{r})^{b b b}$ & N.D. & $4.03(\mathrm{~h})^{b b b}$ \\
\hline
\end{tabular}

h, human; c, cow; d, dog; gp, guinea pig; m, mouse; r, rat; rb, rabbit; N.D., no data available; LUF5981, 8-cyclohexyl-2,6-diphenyl-1-deazapurine; CSC, 8-(3chlorostyryl)caffeine; KF26777, 2-(4-bromophenyl)-4-ethyl-4,5,7,8-tetrahydro-1H-imidazo[2.1-i]purin-5-one.

a Jacobson et al., 1999.

${ }^{b}$ Abo-Salem et al., 2004.

${ }^{c}$ Borrmann et al., 2009.

${ }^{d}$ Kim et al., 2002.

e van Galen et al., 1994

${ }^{f}$ Grahner et al., 1994.

${ }^{g}$ Daly et al., 1991.

${ }^{h}$ Bertarelli et al., 2006.

${ }^{i}$ Müller et al., 2000.

${ }^{j}$ Brackett and Daly, 1994.

${ }^{k}$ Ukena et al., 1986b.

${ }^{l}$ Klotz et al., 1998.

${ }^{m}$ Müller et al., 1993b.

${ }^{n}$ Auchampach et al., 2009.

${ }^{\circ}$ Klotz et al., 1991.

${ }^{p}$ Fozard et al., 2003.

${ }^{q}$ Jacobson et al., 1995.

${ }^{r}$ Auchampach et al., 1997.

$s$ Müller, 2000a.

${ }^{t}$ Weyler et al., 2006.

${ }^{u}$ Hayallah et al., 2002.

${ }^{v}$ Holschbach et al., 2002.

${ }^{w}$ Pfister et al., 1997.

${ }^{x}$ Kiesman et al., 2006b.

${ }^{y}$ Kiesman et al., 2006a.

${ }^{z}$ Doggrell, 2005.

aa Jacobson and Gao, 2006.

${ }^{b b}$ Kalk et al., 2007.

${ }^{c c}$ Chang et al., 2007.

${ }^{d d}$ Müller et al., unpublished data.

ee Kase et al., 2003.

ff Shimada et al., 1997.

gg Pretorius et al., 2008.

hh Jacobson et al., 1993a.

ii Daly and Jacobson, 1995.

ij Sauer et al., 2000.

${ }^{k k}$ Recombinant receptors (expressed in CHO cells).

"l Solinas et al., 2005.

$\mathrm{mm}$ Native receptors (post mortem brain).

${ }^{n n}$ Gillespie et al., 2009

${ }^{o o}$ Minetti et al., 2005.

${ }^{p p}$ Müller and Ferré, 2007.

${ }^{q q}$ Kecskés et al., 2010.

${ }^{r r}$ Kim et al., 2000.

ss Baraldi et al., 2004.

${ }^{t t}$ Borrmann et al., 2009.

uи Elzein et al., 2008.

${ }^{v v}$ Vidal et al., 2007; Eastwood et al., 2010.

$w w$ Saki et al., 2002

${ }^{x x}$ Ozola et al., 2003.

${ }^{y y}$ Müller et al., 2002a.

$z z$ Müller et al., 2002b.

aaa Liang et al., 2010.

$b b b$ van Muijlwijk-Koezen et al., 2000. 


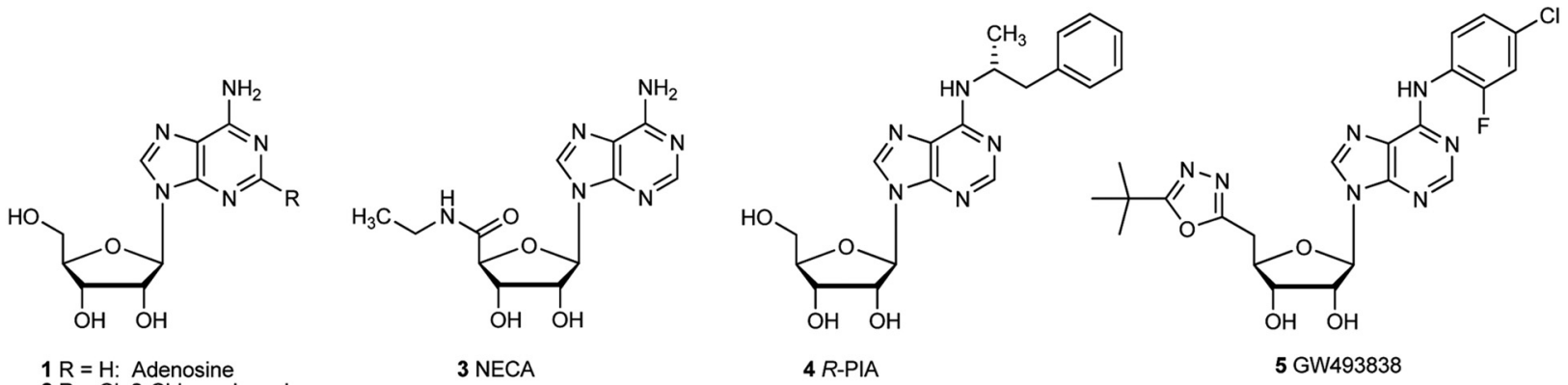

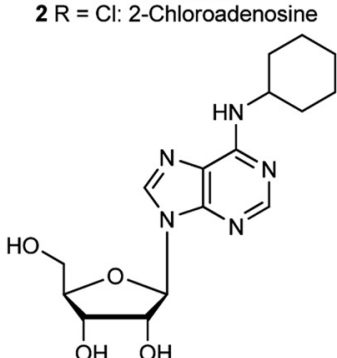

$6 \mathrm{CHA}$

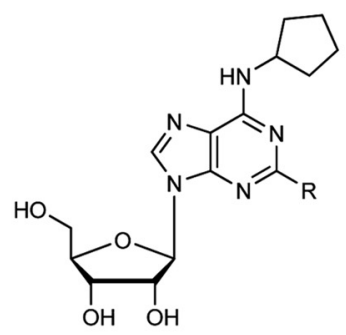

$7 \mathrm{R}=\mathrm{H}: \mathrm{CPA}$
$\mathbf{8} \mathrm{R}=\mathrm{Cl}: \mathrm{CCPA}$

$9 \mathrm{R}=\mathrm{N}=\mathrm{N}-\mathrm{NH}-\mathrm{C}(\mathrm{O})-\mathrm{NH}-\mathrm{Ph}: \mathrm{TCPA}$

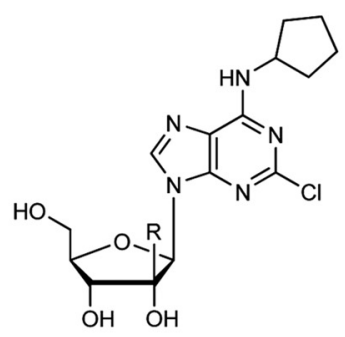

$10 \mathrm{R}=\mathrm{CH}_{3}: 2^{\prime}-\mathrm{Me}-\mathrm{CCPA}$

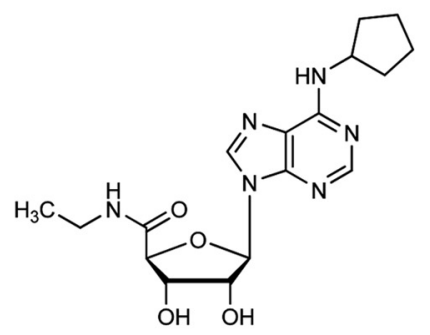

11 Selodenoson (DTI-0009)

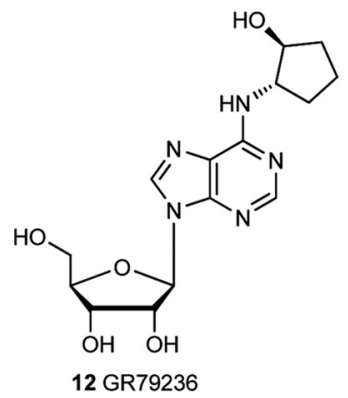<smiles>OC[C@H](O)[C@H](O)[C@H](O)n1cnc2c(N[C@@H]3CCOC3)ncnc21</smiles>

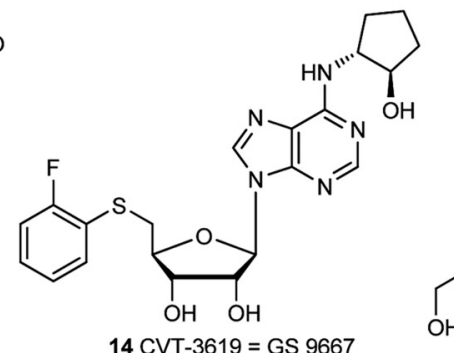<smiles>N#Cc1c(N)nc(SCc2csc(-c3ccc(Cl)cc3)n2)c(C#N)c1-c1ccc(OCCO)cc1</smiles>

FIG. 2. Nonselective and $\mathrm{A}_{1}$-selective agonists.

weakly potent at adenosine receptors. A more potent nonselective antagonist is the triazoloquinazoline derivative 5-amino-9-chloro-2-(2-furyl)[1,2,4] triazolo[1,5-c]quinazoline (CGS15943; 34). A very large number of $\mathrm{A}_{1}$-selective antagonists has been developed derived from the xanthines (e.g., 35-39) or with nonxanthine structure (e.g., 40-42). $\mathrm{A}_{1}$-selective xanthines typically feature a bulky cycloalkyl residue in the 8-position of the xanthine core. DPCPX (35) is the most widely used $A_{1}$ antagonist, although its selectivity is moderate in some species, [e.g., humans (see Table 4)]. It is also available in tritiated form as an $\mathrm{A}_{1}$ antagonist radioligand. A fluorinated derivative8-cyclopentyl-1-propyl-3-(3-[ $\left.{ }^{18} \mathrm{~F}\right]$ fluoropropyl)xanthine $\left(\left[{ }^{18} \mathrm{~F}\right] \mathrm{CPFPX} ; 36\right)$ - has been developed as a tracer for positron emission tomography. The 8-(3-noradamantyl) derivative 1-butyl-8-noradamant-3-yl-3-(3-hydroxypropyl)-3,7dihydropurin-2,6-dione (PSB-36; 38) is more potent than 35 with a $K_{\mathrm{i}}$ value for the rat $\mathrm{A}_{1}$ receptor in the picomolar range. $A_{1}$ antagonists including rolofylline (37), toponafylline (39), $R$-[(E)-3-(2-phenylpyrazolo[1,5-a]pyridin-3-yl) acryloyl]-2-piperidine ethanol (FK-453; 40), and 4-(4hydroxycyclohexylamino)-6-phenylpyrrolo[2,3- $d]$ pyrimidine (SLV320; 41) have been evaluated in clinical trials, but so far no $\mathrm{A}_{1}$-selective antagonist has been approved as a drug.
Many $\mathrm{A}_{2 \mathrm{~A}^{-}}$-selective antagonists from different structural classes have been developed (43-52). One of the first $\mathrm{A}_{2 \mathrm{~A}}$ antagonists was 8-(3-chlorostyryl)caffeine (44). However, $\mathbf{4 4}$ is also a potent inhibitor of monoamine oxidase $B$. Frequently used antagonists of the $A_{2 A}$ receptor are 3-(3-hydroxypropyl)-7-methyl-1-propargyl-8-( $m$-methoxystryryl)xanthine (MSX-2; 45) and its water-soluble prodrugs phosphoric acid mono-(3-\{8-[2-(3-methoxy-phenyl)-vinyl]7-methyl-2,6-dioxo-1-prop-2-ynyl-1,2,6,7-tetrahydropurin3-yl\}-propyl) ester (MSX-3; 45a) and L-valine-3-\{8-(E)-2-[3methoxyphenyl)ethenyl]-7-methyl-1-propargylxanthine-3yl\}propyl ester hydrochloride (MSX-4; 45b), ZM-241385 (48), and 5-amino-7-(2-phenylethyl)-2-(2-furyl)pyrazolo[4,3-e]-1,2,4-triazolo[1,5-c]-pyrimidine (SCH-58261; 50). Compounds 45, 48, and 50 have also been prepared in tritiated form and are used as $\mathrm{A}_{2 \mathrm{~A}}$ antagonist radioligands. ZM-241385 (48) exhibits the lowest degree of selectivity among these three standard $\mathrm{A}_{2 \mathrm{~A}}$ antagonists due to its affinity at the $\mathrm{A}_{2 \mathrm{~B}}$ receptor. Several $\mathrm{A}_{2 \mathrm{~A}}$ antagonists are in clinical trials for Parkinson's disease, including istradefylline (43), 4-hydroxy-4-methylpiperidine-1-carboxylic acid(4-methoxy-7-morpholin-4-ylbenzothiazol-2-yl)amide (SYN-115; 46), 2-butyl-9-methyl-8-[1,2,3]triazol-2-yl-9Hpurin-6-ylamine (ST-1535; 49), preladenant (51), and 2-(2- 
<smiles>CCNC(=O)C1OC2OC(C1O)C(O)C2n1cnc2c(N)nc(NCCc3ccc(CCC(=O)O)cc3)nc21</smiles>

16 CGS21680<smiles>CCNC(=O)C1OC2OC(C1O)C(O)C2O</smiles>

17 Apadenoson (ATL-146e, Stredavase ${ }^{T M}$ )<smiles>CC(=O)N1CCC(CC#Cc2nc(N)c3ncn(C4OC(C(=O)NC5CC5)C(O)C(O)C4O)c3n2)CC1</smiles>

18 ATL-313<smiles></smiles>

19 UK-432097

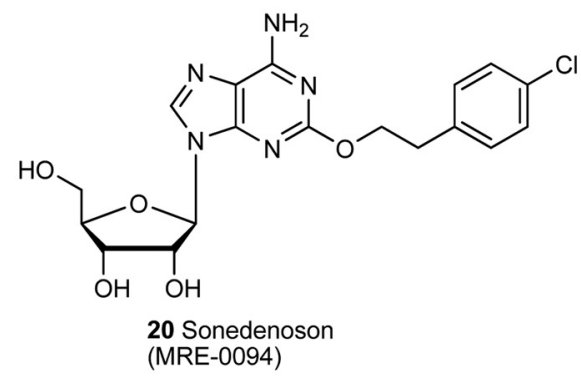

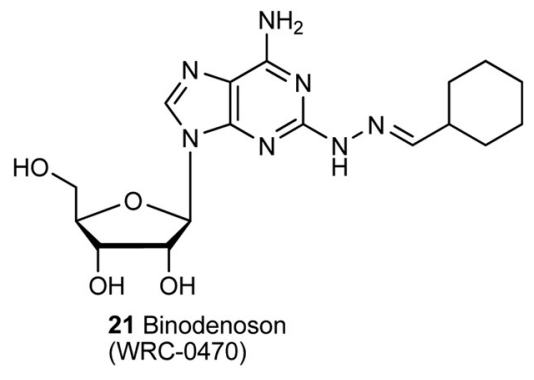

FIG. 3. $\mathrm{A}_{2 \mathrm{~A}}$-selective agonists.

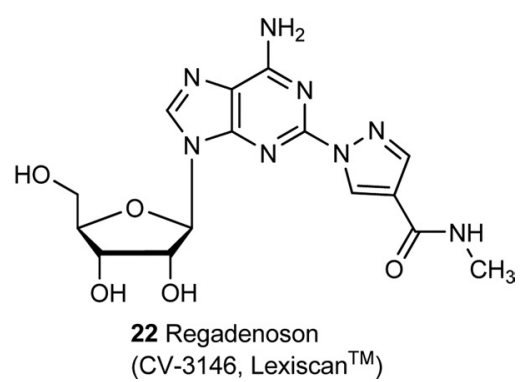

furyl)-7-[3-(4-methoxyphenyl)propyl]-7H-pyrazolo[4,3e] [1,2,4] triazolo[1,5-c]pyrimidin-5-amine ( $\mathrm{SCH}-442416 ; \mathbf{5 2}$ ).

During the past decade, potent and selective $\mathrm{A}_{2 \mathrm{~B}}$ antagonists have been developed (53-59; Table 4). One of the first compounds was the xanthine derivative $N$-(4cyanophenyl)-2-(4-(1,3-dipropylxanthin-8-yl)phenoxy)acetamide (MRS1754; 53), which is potent and selective in humans but not in other species (e.g., rat). Further potent and $\mathrm{A}_{2 \mathrm{~B}}$-selective xanthine derivatives include $N$-benzo[1,3] dioxol-5-yl-2-(5-(2,6-dioxo-1,3-dipropyl2,3,6,7-tetrahydropurin-8-yl)-1-methyl- $1 H$-pyrazol-3- yloxy)acetamide (MRE-2029-F20; 54), 8-(4-(4-(4-chlorophenyl)piperazine-1-sulfonyl)phenyl)-1-propylxanthine (PSB-603; 55), 3-ethyl-1-propyl-8-(1-(3-trifluoromethylbenzyl)-1H-pyrazolo-4-yl)xanthine (CVT-6883; 56), 1-propyl-8- $p$-sulfophenylxanthine (PSB-1115; 57), and $N$-(5-(1cyclopropyl-2,6-dioxo-3-propyl-2,3,6,7-tetrahydro- $1 H$ purin-8-yl)pyridin-2-yl)- $N$-methyl-6-(trifluoromethyl)nicotinamide (ATL 802; 58). The most potent and selective $A_{2 B}$ antagonist yet developed is PSB-603 (55), which shows high affinity and selectivity not only in humans but also in rodents. Compounds $\mathbf{5 3}$ to $\mathbf{5 5}$ have also been prepared in<smiles>CCNC(=O)C1OC2OC(C1O)C(O)C2n1cnc2c(NNC(=O)c3ccco3)ncnc21</smiles>

$23 \mathrm{~A}_{2 \mathrm{~B}}$-selective agonist (Baraldi)<smiles>N#Cc1c(N)nc(SCC(N)=O)c(C#N)c1-c1ccc(OCC2CC2)cc1</smiles>

FIG. 4. $\mathrm{A}_{2 \mathrm{~B}}$-selective agonists. 


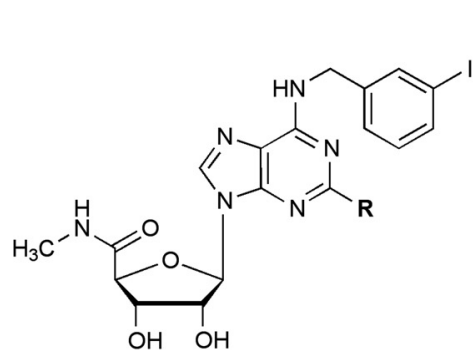

$25 \mathbf{R}=\mathrm{H}:$ IB-MECA (CF101) $26 \mathrm{R}=\mathrm{Cl}: \mathrm{Cl}-\mathrm{IB}-\mathrm{MECA}(\mathrm{CF} 102)$

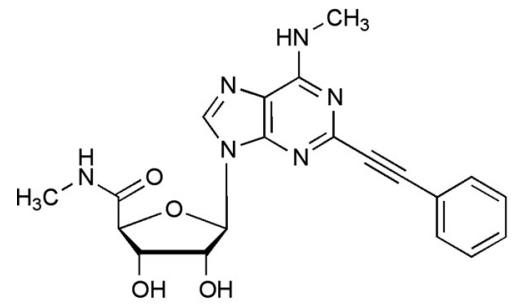

29 2-Phenylethynyl-adenosine derivative (Volpini, Cristalli)

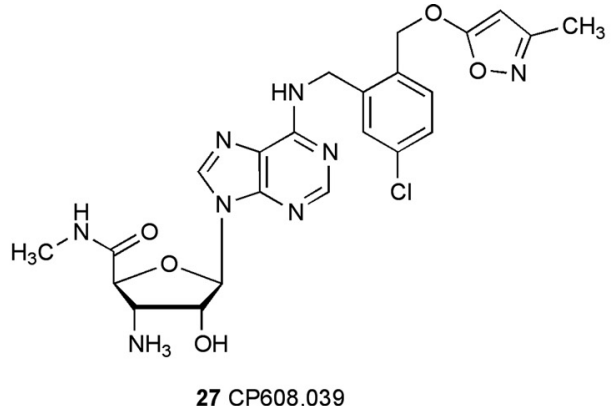

27 CP608,039

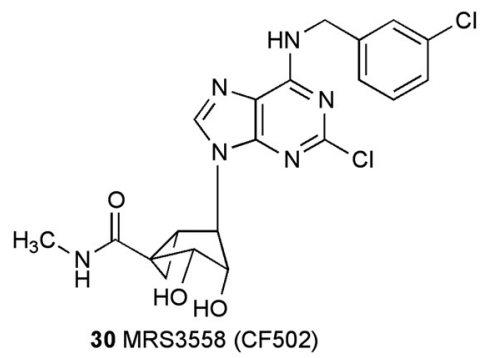

FIG. 5. $\mathrm{A}_{3}$-selective agonists.

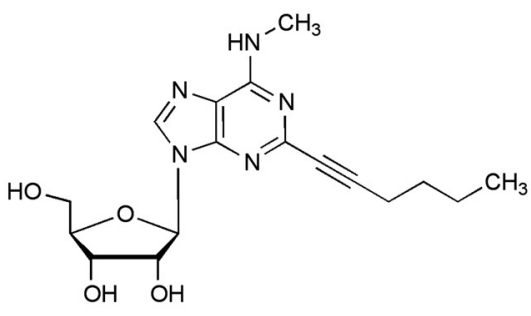

28 HEMADO<smiles>CNC(=O)C1(O)C2C(O)C(O)C1C(C)(C)C2n1cnc2c(NCc3cccc(Cl)c3)nc(C#CCCCC(=O)O)nc21</smiles>

tritium-labeled form as antagonist $\mathrm{A}_{2 \mathrm{~B}}$ radioligands. PSB1115 (57) is particularly useful for in vivo studies because it shows high water solubility; however, its $\mathrm{A}_{2 \mathrm{~B}}$ affinity and selectivity are lower than those of the more lipophilic compounds. The xanthine CVT-6883 (56) is in clinical trials for the treatment of chronic obstructive pulmonary disorder. Besides xanthines derivatives, nonxanthine $\mathrm{A}_{2 \mathrm{~B}}$ antagonists have recently been developed, such as 2-amino4-(2-furanyl)-5-(4-pyrimidinyl)pyrimidine (LAS38096; 59).

The $\mathrm{A}_{3}$ receptor is characterized by particularly large species differences between human and rodent orthologs, especially for antagonists. Known heterocyclic $\mathrm{A}_{3}$ antagonists are typically much more potent at the human compared with the rat receptor. Therefore, their use in mouse or rat studies is questionable. An exception is the pyridine derivative 5-propyl-2-ethyl-4-propyl-3-(ethylsulfanylcarbonyl)-6-phenylpyridine-5-carboxylate (MRS1523; 64), which is quite potent at rat $A_{3}$ receptors as well. Frequently used potent and $\mathrm{A}_{3}$-selective tool compounds include 8-ethyl-4methyl-2-(2,3,5-trichlorophenyl)-(8R)-4,5,7,8-tetrahydro- $1 H$ imidazo[2.1-i]purin-5-one (PSB-10; 61), 8-ethyl-4-methyl-2phenyl-(8R)-4,5,7,8-tetrahydro- $1 H$-imidazo[2.1-i]purin-5-one (PSB-11; 62), 5-[(4-methoxyphenyl)amino]carbonyl]amino-8propyl-2-(2-furyl)pyrazolo[4,3-e]1,2,4-triazolo[1,5-c]pyrimidine (MRE3008-F20; 63), 1,4-dihydro-2-methyl-6-phenyl-4(phenylethynyl)-3,5-pyridinedicarboxylic acid, 3-ethyl 5 -(phenylmethyl) ester (MRS1191; 65) and $N$-(2-methoxyphenyl)- $N$-[2-(3-pyridyl)quinazolin-4-yl] urea (VUF-5574; 66). PSB-11 (62) and MRE3008-F20 (63) have been prepared in tritiated form as $\mathrm{A}_{3}$ antagonist radioligands. The imidazopurine derivatives 60 to 62 have the advantage of being less lipophilic and more water-soluble than most of the other $\mathrm{A}_{3}$ antagonists because of a basic nitrogen atom that can be protonated.

\section{Allosterism}

\section{A. Allosteric versus Orthosteric Ligands}

Most of the efforts in the medicinal chemistry and pharmacology of adenosine receptors have concentrated on competitive agonist or antagonist ligands that occupy the principle (orthosteric) binding sites of the receptors. More recently, the area of allosteric modulation of the action of a native agonist has become the focus of widespread efforts in ligand design and pharmacology of these receptors. Each of the four subtypes of the ARs now has selective agonist and antagonist ligands. Allosteric modulators, on the other hand, are well explored only for $A_{1}$ and $A_{3}$ receptors, with isolated reports of examples for allosteric or "noncompetitive" (i.e., potentially allosteric) ligands for other subtypes of purine receptors (Gao et al., 2005). Most of the examples of allosteric modulators of adenosine receptors are positive allosteric modulators (PAMs) (i.e., they increase the affinity, potency, and/or efficacy of the agonist).

The justification for studying allosteric modulation of ARs is clear:

1. First, adenosine receptors are widely distributed throughout the body, yielding a risk for side effects when direct orthosteric agonist is administered. At least for the ARs, the problem of a lack of selective ligands, as has plagued the muscarinic acetylcholine receptor field, is not a limitation for the AR field. However, the ubiquity of the ARs does present a problem of lack of selectivity even for highly selective agonists.

2. Native adenosine is rapidly degraded and does not migrate beyond the target site. In stress situations, the extracellular concentration of adenosine is ele- 
<smiles>Cn1c(=O)c2c(ncn2C)n(C)c1=O</smiles>

32 Caffeine<smiles>Cn1c(=O)c2[nH]cnc2n(C)c1=O</smiles>

33 Theophylline (Aminophylline: 33 : ethylenediamine $=2: 1$<smiles>Nc1nc2ccc(Cl)cc2c2nc(-c3ccco3)nn12</smiles>

34 CGS15943<smiles>CCCn1c(=O)c2[nH]c(C3CCCC3)nc2n(CCC)c1=O</smiles>

$35 \mathrm{DPCPX}(\mathrm{CPX})$<smiles>CCCn1c(=O)c2[nH]c(C3CCCC3)nc2n(CCC(F)F)c1=O</smiles>

$36\left[{ }^{18} \mathrm{~F}\right] \mathrm{CPFPX}$

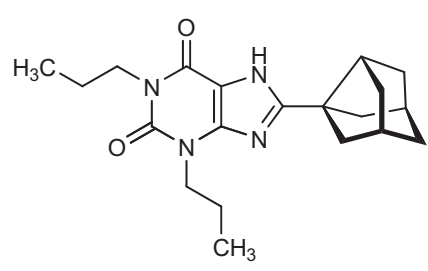

37 Rolofylline (KW3902, NAX)

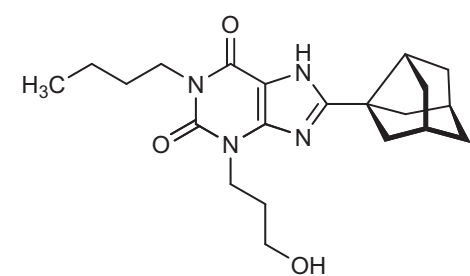

38 PSB-36<smiles>CCCn1c(=O)c2[nH]c(CC34CCC(CCC(=O)O)(CC3)C4)nc2n(CCC)c1=O</smiles>

39 Toponafylline (BG-9928)

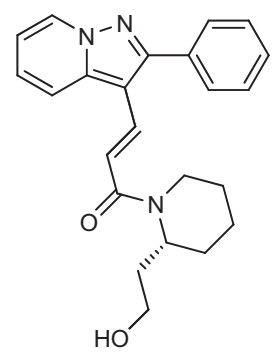

40 FK-453

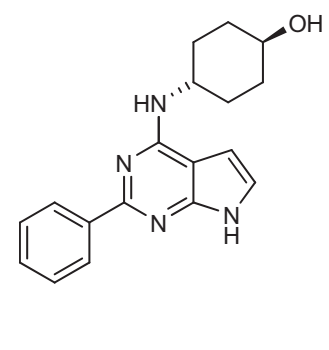

41 SLV320<smiles>c1ccc(-c2cc(-c3ccccc3)c3nc(C4CCCCC4)[nH]c3n2)cc1</smiles>

42 LUF5981

FIG. 6. Nonselective and $\mathrm{A}_{1}$-selective antagonists.

vated locally. Thus, the action of a PAM is expected to be more tissue-specific than the action of a stable, exogenously administered orthosteric agonist, which would circulate throughout the body (Conn et al., 2009).

3. Adenosine agonists do not readily penetrate the blood-brain barrier. The brain entry of nucleoside derivatives is typically only 1 to $2 \%$ of free passage across the blood-brain barrier. Thus, for induction of adenosine receptor activation in the brain, where adenosine levels can be greatly elevated in response to stress or hypoxia, a freely penetrating PAM would be more effective.

These factors make allosteric enhancement of receptor activation by endogenous adenosine a particularly attractive option-leading to site-specific and event-specific action, with a particular advantage in the central nervous system.

Assay methods used to identify allosteric modulators of the adenosine receptors have included both radioligand binding and functional assays. Initially, screening typically has consisted of looking for an increase in the level of binding of radioligand to membranes expressing a given receptor subtype. A more labor-intensive binding method has been to look for alteration of the dissociation rate of a radioligand. Thus, slowing the off rate of an agonist is one indication of a PAM, although it is not conclusive until at least one functional assay is carried out. Such functional assays might consist of the enhancement (for a PAM) or reduction [for a negative allosteric modulator (NAM)] of binding of a radiolabeled guanine nucleotide in response to a known receptor agonist or effects on agonist-induced changes in adenylate cyclase or other second-messenger systems.

\section{B. $A_{1}$ Receptor Allosteric Modulators}

The benzoylthiophenes were the first AR allosteric modulators to be identified (Bruns et al., 1990). They have been extensively modified in subsequent studies, and their structure-activity relationship (SAR) as PAMs has been documented. The prototypical benzoylthiophene to act as an $A_{1}$ receptor allosteric modulator is (2-amino-4,5-dimethyl-3thienyl)(3-(trifluoromethyl)phenyl)-methanone (PD81,723; Fig. 10), and many analogs have been prepared (Kourounakis et al., 2000; Baraldi et al., 2007a,b). The 2-amino3-carbonylthiophene moiety is required as a minimal pharmacophore. The aroyl group can be substituted with other phenyl and heteroaromatic groups. The 4,5-alkyl substituents of the thiophene ring may be cyclized, particularly with cyclohexyl group (van der Klein et al., 1999), although larger rings are also tolerated (Nikolakopoulos et al., 2006). In certain cases, the aroyl group 
<smiles>CCn1c(=O)c2c(nc(/C=C/c3ccc(OC)c(OC)c3)n2C)n(CC)c1=O</smiles>

43 Istradefylline (KW-6002)<smiles>[R]c1cccc(/C=C/c2nc3c(c(=O)n(C)c(=O)n3C)n2C)c1</smiles>

$44 \mathrm{CSC}$<smiles>[R]OCCCn1c(=O)n(CC#C)c(=O)c2c1nc(/C=C/c1cccc(OC)c1)n2C</smiles>

$45 \mathrm{R}=\mathrm{H}: \quad \mathrm{MSX}-2$ 45a $\mathrm{R}=\mathrm{PO}_{3} \mathrm{Na}_{2}: \mathrm{MSX}-3$ (prodrug)

45b $\mathrm{R}=$ MSX-4 (prodrug)<smiles>COc1ccc(N2CCOCC2)c2sc(NC(=O)N3CCC(C)(O)CC3)nc12</smiles><smiles>Cc1cc(Cn2nnc3c(-c4ccco4)nc(N)nc32)ccc1N</smiles><smiles>Nc1nc(NCCc2ccc(O)cc2)nc2nc(-c3ccco3)nn12</smiles>

48 ZM-241385<smiles>CCCCc1nc(N)c2nc(-n3nccn3)n(C)c2n1</smiles>

$49 \mathrm{ST}-1535$<smiles>Nc1nc2c(cnn2CCc2ccccc2)c2nc(-c3ccco3)nn12</smiles>

50 SCH-58261<smiles>COCCOc1ccc(N2CCN(CCn3ncc4c3nc(N)n3nc(-c5ccco5)nc43)CC2)cc1</smiles>

FIG. 7. $\mathrm{A}_{2 \mathrm{~A}}$-selective antagonists.

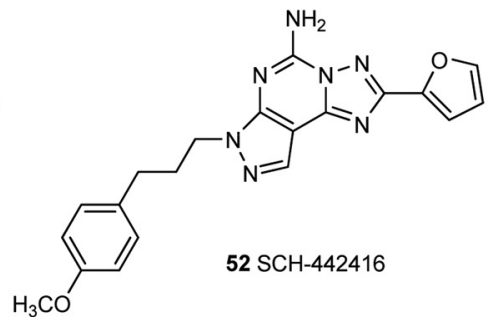

can be simplified in the form of a carboxylic acid. An atypical structural class, 2-aminothiazoles, were reported as AR allosteric enhancers, but their activity as
PAMs is not always evident and seems to be limited to specific salt forms (Chordia et al., 2005; Göblyös et al., 2005).<smiles>CCCn1c(=O)c2[nH]c(-c3ccc(OCC(=O)Nc4ccc(C#N)cc4)cc3)nc2n(CCC)c1=O</smiles>

53 MRS1754<smiles>CCCn1c(=O)[nH]c2nc(-c3ccc(S(=O)(=O)N4CCN(C)CC4)cc3)[nH]c2c1=O</smiles>

55 PSB-603<smiles>Cc1ccc(Cl)cc1</smiles><smiles>CCCn1c(=O)c2[nH]c(-c3cc(OCC(=O)Nc4ccc5c(c4)OCO5)nn3C)nc2n(CCC)c1=O</smiles>

54 MRE-2029-F20<smiles>CCCn1c(=O)c2[nH]c(-c3cnn(Cc4cccc(C(F)(F)F)c4)c3)nc2n(CC)c1=O</smiles><smiles>CCCn1c(=O)[nH]c2nc(-c3ccc(S(=O)(=O)O)cc3)[nH]c2c1=O</smiles>

57 PSB-1115

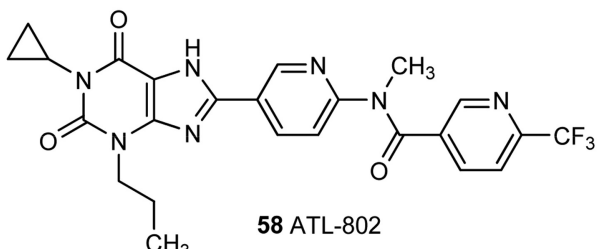<smiles>c1cncc(Nc2ncc(-c3ccncn3)c(-c3ccco3)n2)c1</smiles>

59 LAS38096

FIG. 8. $\mathrm{A}_{2 \mathrm{~B}^{-}}$selective antagonists. 
<smiles>CCCN1C(=O)N2CCN=C2c2[nH]c(-c3ccc(Br)cc3)nc21</smiles>

60 KF26777<smiles>CCCOC(=O)c1c(-c2ccccc2)nc(CC)c(C(=O)SCC)c1CCC</smiles>

64 MRS1523<smiles>[R]c1cc([R])c([R])c(-c2nc3c([nH]2)C2=N[C@H](CC)CN2C(=O)N3C)c1</smiles>

$61 \mathrm{R}=\mathrm{Cl}: \mathrm{PSB}-10$ $62 \mathrm{R}=\mathrm{H}:$ PSB-11<smiles>CCOC(=O)C1=C(C)NC(c2ccccc2)=C(C(=O)OCc2ccccc2)C1C#Cc1ccccc1</smiles>

65 MRS-1191<smiles></smiles><smiles>COc1ccc(NC(=O)Nc2nc(-c3cccnc3)nc3ccccc23)cc1</smiles>

66 VUF-5574

FIG. 9. $\mathrm{A}_{3}$-selective antagonists.

Only one allosteric modulator of adenosine receptors, the benzoylthiophene analog 2-amino-3-(4-chlorobenzoyl)-5,6,7,8-tetrahydrobenzothiophene (T-62; Baraldi et al., 2000), has until now been in clinical trials. A main envisioned application of T-62 is in the central nervous system, and it seems to alleviate chronic pain. In brain slices, this PAM selectively enhances the coupling of the $A_{1}$ receptor to its $G_{i}$ protein. T-62 itself has agonist properties, because it also raises the basal levels of guanosine $5^{\prime}-O-\left(3-\left[{ }^{35} \mathrm{~S}\right]\right.$ thio $)$ triphosphate binding. An antinociceptive effect has been studied after T-62 administered intrathecally in carrageenan-inflamed rats. This allosteric adenosine receptor modulation reduced hypersensitivity after peripheral inflammation by a central mechanism ( $\mathrm{Li}$ et al., 2003). T-62 has been radiolabeled, and its binding properties are indicative of allosteric binding (Baraldi et al., 2006).

Another possible advantage of PAMs over orthosteric agonists is the possibility to alter the spectrum of second-messenger effects, or produce a bias toward a particular pathway based on conformational variation of the receptor in its activated state. In this context, a new 3,5-di(trifluoromethyl)benzoylthiophene derivative was shown to act as an alloagonist of the A1AR (Aurelio et al., 2009). Activation of the extracellular signal-regulated kinase phosphorylation pathway required higher concentrations of the derivative than for $\mathrm{G}$ protein modulation (based on guanosine $5^{\prime}-O-\left(3-\left[{ }^{35} \mathrm{~S}\right]\right.$ thio $)$ triphosphate binding $)$, suggesting the possibility of signaling bias. Such functional selectivity was corroborated in a recent study with a number of allosteric modulators, in which it was also shown that some modulators are direct inhibitors of $\mathrm{G}$ protein function (Valant et al., 2010).

Bivalent ligands linking both orthosteric (adenosinelike) and allosteric (PD81,723-like) pharmacophores were recently synthesized (Narlawar et al., 2010). $N^{6}$-[2-Amino3-(3,4-dichlorobenzoyl)-4,5,6,7-tetrahydrothieno[2,3c]pyridin-6-yl-9-nonyloxy-4-phenyl]adenosine (LUF6258; Fig. 11) with a nine-carbon atom linker between the two pharmacophores showed no significant changes in affinity or potency in the presence of PD81,723, indicating that LUF6258 bridged both orthosteric and allosteric binding sites on the receptor.

\section{C. $A_{2 A}$ Receptor Allosteric Modulators}

Amiloride analogs have been characterized as allosteric modulators of the $\mathrm{A}_{2 \mathrm{~A}}$ adenosine receptor (Gao and IJzerman, 2000). 5-(N,N-Dialkyl)amiloride derivatives, such as 5 -( $N, N$-hexamethylene)amiloride (Fig. 10), increase the dissociation rate of antagonist radioligand at this subtype. However, these compounds are not selective for this subtype or for adenosine receptors in general. They also allosterically modulate action at both $A_{1}$ and $A_{3}$ receptors (Gao et al., 2003b). At the $A_{1}$ adenosine receptor, their behavior is similar to that at the $A_{2 A}$ receptor. At the $A_{3}$ receptor, they additionally decrease the dissociation rate of agonist radioligand. They also compete for orthosteric binding at these three subtypes. Thus, amiloride analogs are of limited use as allosteric pharmacological probes. 
A<smiles>Cc1sc(N)c(C(=O)c2cccc(C(F)(F)F)c2)c1C</smiles>

PD81,723

Bruns et al. 1990<smiles>Nc1sc2c(c1C(=O)O)CCCCC2</smiles>

Nikolakopoulos et al. 2006<smiles>[R]c1ccc(C(=O)c2c(N)sc3c2CCCC3)cc1[R]</smiles>

PD71,605 $\mathrm{R}^{1}=\mathrm{Cl}, \mathrm{R}^{2}=\mathrm{H}$ Bruns et al. 1990

LUF5484 $\mathrm{R}^{1}=\mathrm{R}^{2}=\mathrm{Cl}$ van der Klein et al. 1999

$\mathrm{T}-62 \mathrm{R}^{1}=\mathrm{H}, \mathrm{R}^{2}=\mathrm{Cl}$

Baraldi et al. 2000<smiles>Nc1scc(-c2cc(C(F)(F)F)cc(C(F)(F)F)c2)c1C(=O)c1ccccc1</smiles>

Aurelio et al. 2009<smiles>CC(=O)Oc1ccc2c(c1)CCc1sc(N)nc1-2</smiles>

Chordia et al. 2005

Göblyös et al. 2005<smiles>Nc1scc(N2CCN(c3ccc(C(F)(F)F)cc3)CC2)c1C(=O)c1ccc(Cl)cc1</smiles>

Romagnoli et al. 2008

B<smiles>O=C(Nc1ccc(F)cc1)Nc1ccc(Nc2nc(-c3ccccc3)nc3c2nnn3Cc2ccccc2)cc1</smiles><smiles>N=C(N)NC(=O)c1nc(Cl)c(N2CCCCCC2)nc1N</smiles>

FIG. 10. Selected allosteric enhancers of action of agonist at the $A_{1}$ adenosine receptor (A) and at the $A_{2 A}$ receptor (B).

A 2-phenyl-9-benzyl-8-azaadenine derivative (Fig. 10) was reported to be an allosteric enhancer of radioligand binding at the $\mathrm{A}_{2 \mathrm{~A}}$ adenosine receptor and agonist-induced relaxation of rat aortic rings (Giorgi et al., 2008). The benzopyran-2-one derivative 4-methyl-2-oxo- $2 H$ chromen-7-yl methylcarbamate (PD120,918) was also reported to be an enhancer of binding at the $\mathrm{A}_{2 \mathrm{~A}}$ receptor (Gao et al., 2005).

\section{D. $A_{3}$ Receptor Allosteric Modulators}

Structurally diverse classes of allosteric modulators for the $\mathrm{A}_{3}$ adenosine receptor were discovered during screening of known ligands of this subtype (Gao et al., 2001, 2002). Prototypical PAMs of the $\mathrm{A}_{3}$ receptor include 3-(2-pyridinyl)isoquinolines [e.g., 4-methoxy- $N$-(7methyl-3-(2-pyridinyl)-1-isoquinolinyl)benzamide) (VUF5455)] and $1 H$-imidazo-[4,5-c]quinolin-4-amines [e.g., 2-cyclopentyl-4-phenylamino- $1 H$-imidazo-[4,5-c]quinoline (DU124183) and $N$-(3,4-dichlorophenyl)-2-cyclohexyl- $1 H$ imidazo-[4,5-c]quinolin-4-amine (LUF6000) (Göblyös et al., 2006)].

The $\mathrm{A}_{3} \mathrm{AR}$ selective antagonist VUF-5574 $\left(K_{\mathrm{i}}, 4 \mathrm{nM}\right)$ belongs to the class of pyridinyl isoquinolines, a chemical series that was originally introduced as antago- 


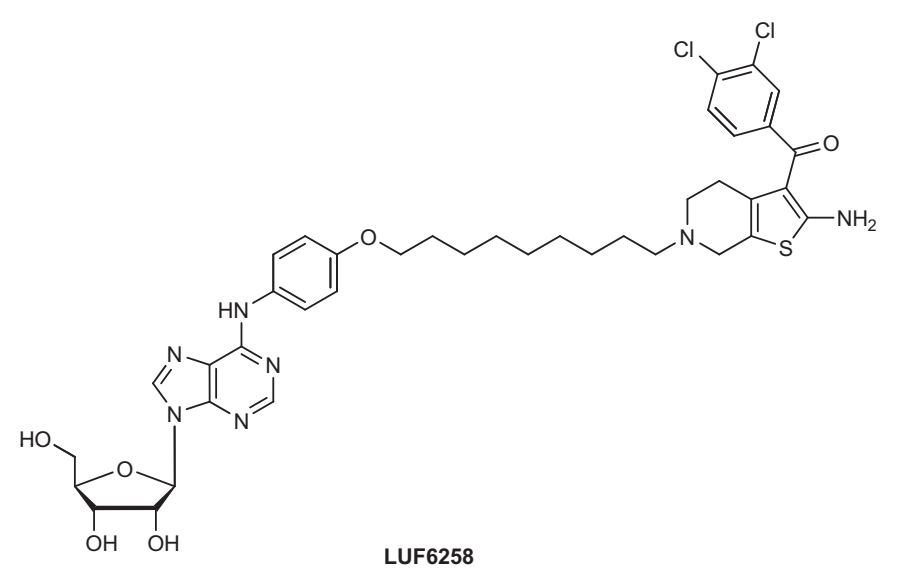

FIG. 11. Bivalent ligand bridging orthosteric and allosteric site on the human $\mathrm{A}_{1}$ adenosine receptor.

nists of this subtype (van Muijlwijk-Koezen et al., 1998). In binding assay screens of diverse ligands designed to detect enhancement, as well as inhibition, members of the pyridinyl isoquinoline class were found to exhibit allosteric as well as orthosteric properties in interaction with the receptor (Fig. 12). The SAR of pyridinyl isoquinolines in orthosteric binding to the $\mathrm{A}_{3}$ adenosine receptor (presumed from the competitive displacement of orthosteric radioligands) is distinct from SAR in allosteric enhancement. Because many structural homologues were already available, it was feasible to characterize their profile as allosteric enhancers of $\mathrm{A}_{3}$ adenosine receptor.

Another structural class of $\mathrm{A}_{3}$ adenosine receptor PAMs are the imidazoquinolinamines (Gao et al., 2002). van Galen et al. (1991) originally introduced the imida- zoquinolinamines as $\mathrm{A}_{1}$ receptor antagonists. In addition to orthosteric binding competitive with the native ligand adenosine, the compound DU124183 was an allosteric enhancer of radioligand binding at the $\mathrm{A}_{3}$ adenosine receptor.

The SAR of a series of imidazoquinolinamines as allosteric enhancers of the $\mathrm{A}_{3}$ adenosine receptor has been explored in detail. Modification of the 4 position shows a divergence of the structural requirements for orthosteric and allosteric actions. Combination of the most favorable groups for allosteric enhancement is shown in Fig. 3, resulting in the prototypical $\mathrm{A}_{3}$ receptor PAM of the imidazoquinolinamine class, LUF6000. Allosteric enhancement was demonstrated by reducing the dissociation rate of agonist radioligand and by enhancement of maximal guanine nucleotide binding in<smiles>COc1ccc(C(=O)Nc2nc(-c3ccccn3)cc3ccc(C)cc23)cc1</smiles><smiles>CCCCC/C=C\C/C=C\C/C=C\CCCC(=O)OC(CO)CO</smiles>

2-Arachidonoylglycerol Lane et al. 2010

VUF5455

Gao et al. 2001<smiles>c1ccc(Nc2nc3ccccc3c3nc(C4CCCC4)[nH]c23)cc1</smiles>

DU 124183

Gao et al. 2001<smiles>Clc1ccc(Nc2nc3ccccc3c3nc(C4CCCCC4)[nH]c23)cc1Cl</smiles>

LUF6000 Göblyös et al. 2006<smiles>[R]c1nc2c([nH]1)c(Nc1ccccc1)nc1ccccc12</smiles>

$\mathrm{R}^{1}=3,4-$ or 3,5 -dichloro $\mathrm{R}^{2}=$ cycloalkyl or bicycloalkyl Kim et al. 2009<smiles>O=C(Nc1cc(Nc2ccc(Cl)c(Cl)c2)nc2ccccc12)C1CCCCC1</smiles>

Heitman et al. 2009

FIG. 12. Structures of pyridinylisoquinoline and imidizoquinolinamine derivatives that act as PAMs of of the human $\mathrm{A}_{3}$ adenosine receptor and structure of 2-AG, which acts as a NAM of the $\mathrm{A}_{3}$ receptor. 
the presence of a known agonist. No major effect on potency of prototypical agonist Cl-IB-MECA at the human $\mathrm{A}_{3}$ adenosine receptor by LUF6000 was observed. The allosteric effects were increased without increasing the orthosteric inhibition by altering the size of the 2-cycloalkyl ring and by substitution of the 4-phenylamino group. Further exploration of steric and electronic effects of substitution at the 2 and 4 positions of a series of imidazoquinolinamines as allosteric enhancers of the $\mathrm{A}_{3} \mathrm{AR}$ was reported (Kim et al., 2009b). Enhancement was observed by two bridged bicycloalkyl derivatives, indicating that rigid steric bulk is tolerated at the 2 position. Hydrophobicity is also a requirement at that position. Scission of the imidazole ring in the structure of LUF6000 (Fig. 12) led to a series of 2,4-disubstituted quinolines as allosteric enhancers of the adenosine $\mathrm{A}_{3}$ receptor. The same substitution pattern as in LUF6000 led to the most potent allosteric modulator $[N$ - $\{2-[(3,4$-dichlorophenyl)amino] quinoline-4-yl $\}$ cyclohexanecarboxamide (LUF6096)] in the series with negligible orthosteric activity on $A_{1}$ and $A_{3}$ receptors, even less than observed for LUF6000 (Heitman et al., 2009).

The ability of nucleoside derivatives to activate as well as bind to the $\mathrm{A}_{3}$ adenosine receptor is highly structuredependent. It is even possible to modify nucleoside agonists to become selective $A_{3}$ adenosine receptor antagonists. The allosteric enhancer LUF6000 was found to "revive" a potently binding nucleoside antagonist at the human $\mathrm{A}_{3}$ receptor, 2-chloro- $N^{6}$-(3-iodobenzyl)-adenosine (MRS592) (Gao et al., 2008). This nucleoside derivative, although having an intact ribose moiety, contains two modifications that diminish the efficacy of the compound at the $\mathrm{A}_{3}$ receptor but do not prevent its highaffinity receptor binding. Coadministration of LUF6000, up to $10 \mu \mathrm{M}$, converted this full antagonist into a full agonist in a concentration-dependent manner, which is an example of a complete reversal of the nature of the action of an antagonist by a PAM of a GPCR. This phenomenon was observed only with nucleoside-based antagonists, and not with heterocyclic antagonists of the $\mathrm{A}_{3}$ receptor such as $N$-[9-chloro-2-(2-furanyl)[1,2,4]triazolo[1,5-c]quinazolin-5-yl]benzene acetamide (MRS1220).

Some endogenous cannabinoid ligands also modulate the $\mathrm{A}_{3}$ receptor (Lane et al., 2010). 2-Arachidonylglycerol (2-AG) was able to inhibit agonist ${ }^{125} \mathrm{I}$-4-aminobenzyl-5'-N-methyl-carboxamidoadenosine binding at the human $\mathrm{A}_{3}$ adenosine receptor. In the presence of 2-AG, the rate of ${ }^{125} \mathrm{I}-4$-aminobenzyl-5' $-N$-methyl-carboxamidoadenosine dissociation was increased, suggesting that 2-AG acts as a NAM. Because the human $\mathrm{A}_{3}$ adenosine receptor is expressed in astrocytes and microglia, these findings may be relevant in cerebral ischemia, a pathological condition in which levels of $2-\mathrm{AG}$ are raised.
E. Evidence for Mode of Binding of Adenosine Receptor Allosteric Modulators

Site-directed mutagenesis of the human $\mathrm{A}_{1}$ adenosine receptor (Barbhaiya et al., 1996; Kourounakis et al., 2001; de Ligt et al., 2005; Heitman et al., 2006) and chimera with the $\mathrm{A}_{2 \mathrm{~A}}$ receptor (Bhattacharya et al., 2006) have provided some insight into the structural basis of allosteric modulation. On this receptor subtype, Asp55 in TM2 is probably responsible for allosteric regulation of ligand binding by sodium ions and amilorides, whereas upon G14T (TM1) and T277A (TM7) mutagenesis, PD81,723 loses its enhancing activity with respect to CPA. However, the potency of CPA alone is also drastically diminished by these mutations; hence, it remains unclear whether these two amino acids are also part of the PD81,723 binding site.

Site-directed mutagenesis of the human $\mathrm{A}_{3}$ adenosine receptor has shown that His in TM3 and Phe in TM5 are important for orthosteric binding of the imidazoquinolinamine DU124183 (Gao et al., 2003a). His in TM7 is required for radioligand binding. Other residues, such as Trp243 and Asn30, were modulatory. It was determined that Asn274 in TM7 was required for allosteric binding of the imidazoquinolinamine but not for maintaining the orthosteric binding site. A conserved His residue in TM7 is required for $\mathrm{A}_{3}$ radioligand binding; therefore, it was not possible to establish the effect of its mutation to Ala on allosteric enhancement.

A docking hypothesis for a pyridinylisoquinoline PAM, VUF5455, in the agonist-occupied human $\mathrm{A}_{3}$ adenosine receptor was reported based on an energetically favorable interaction of this heterocyclic derivative with the outer portions of the receptor-near the extracellular loops (Gao et al., 2003a). This would allow the simultaneous binding of both agonist and PAM to different regions of the receptor protein, as has been shown for allosteric modulation of muscarinic receptors (Conn et al., 2009). An alternate hypothesis for the binding of allosteric enhancers in family A GPCRs is that agonists and PAMs might bind on opposite protomers of homodimeric receptor pairs (Schwartz and Holst, 2006). The applicability of this hypothesis to PAMs of the adenosine receptors has yet to be demonstrated.

In conclusion, 2-amino-3-aroylthiophene derivatives (such as T-62 for chronic pain) are under development as allosteric enhancers of the $\mathrm{A}_{1}$ adenosine receptor. These derivatives tend to act as allosteric agonists, as well as PAMs. Two classes of $\mathrm{A}_{3}$ AR allosteric modulators have been explored: 3-(2-pyridinyl) isoquinolines (e.g., VUF5455) and $1 H$-imidazo-[4,5c]quinolin-4-amines (e.g., DU124183 and LUF6000), which selectively decreased the agonist dissociation rate at human $A_{3} A R s$ but not at $A_{1} A R s$ and $A_{2 A} A R s$. The antagonist properties have been minimized in SAR studies. Nucleoside derivatives that are $\mathrm{A}_{3}$ selective antagonists and low-efficacy agonists can be 
converted into full agonists by coadministration of allosteric enhancer LUF6000. Site-directed mutagenesis of $A_{1}$ and $A_{3}$ receptors has identified residues associated with the allosteric effect. Distinct amino acid residues affect orthosteric versus allosteric binding. Thus, there are clear advantages to the design of allosteric modulators of ARs.

\section{Drugs in the Clinic}

What follows is a survey of some of the compounds targeting adenosine receptors that have been investigated in ongoing or recently completed clinical trials. The list is not complete because several early trials in Europe and Japan are not included. Where appropriate, we have included the National Institutes of Health clinical trial identifier.

\section{A. Adenosine}

Newly identified targets of adenosine signaling have triggered new ideas for human investigation of adenosine itself. It is well known that adenosine has long been registered for treatment of supraventricular tachyarrhythmia; therefore, a suitable preparation for use in humans is available. The following is a summary of some of these studies.

1. Inflammation. Investigators at Vanderbilt University are studying the Role of Adenosine in the Release of VEGF and Cytokines (www.clinicaltrials.gov identifier NCT00580905). This trial will determine whether intravenous or intradermal adenosine influences cytokine production in man. This is based on research demonstrating that in animals, adenosine enhances the release of cytokines by activating $\mathrm{A}_{2 \mathrm{~B}}$ or $\mathrm{A}_{3}$ receptors (Ryzhov et al., 2008). Related to this is a study at Radboud University entitled A Possible Therapeutic Role for Adenosine During Inflammation (www.clinicaltrials.gov identifier NCT00513110). This study is based on the observation that a C34T-polymorphism of the enzyme AMP-deaminase alters adenosine metabolism. The hypothesis to be tested is that individuals with polymorphisms that result in increased adenosine will display less inflammation in response to LPS and that caffeine consumption will enhance inflammation in response to LPS.

2. Cardioprotection. Investigators at the University of Ottawa Heart Institute are investigating Prophylactic Intracoronary Adenosine to Prevent Postcoronary Artery Stenting Myonecrosis (www.clinicaltrials. gov identifier NCT00612521). Adenosine acting at $\mathrm{A}_{2 \mathrm{~A}}$ or $\mathrm{A}_{3}$ receptors has been found to reduce reperfusion injury after coronary artery occlusion (Yang et al., 2006; Wan et al., 2008). The aim of this study is to assess whether the use of intracoronary adenosine given directly into the coronary artery before stenting can reduce the incidence of myocardial necrosis and achieve better outcomes at 30-day follow-up. A similar study is under way at the University Hospital, Gasthuisberg, entitled Salvage: Postconditioning with Adenosine for STEMI (www.clinicaltrials.gov identifier NCT00284323). The goal of this study is to investigate the effect of intracoronary administration of adenosine on myocardial salvage and microvascular integrity in the setting of acute myocardial infarction. Another cardioprotection study is underway at Hospital Universitari Vall d'Hebron Research Institute, entitled Myocardial Protection with Adenosine during Primary Percutaneous Coronary Intervention in Pts with STEMI (PROMISE) (www.clinicaltrials.gov identifier NCT00781404). This study will test the effect of a brief intracoronary infusion of adenosine applied at the time of reperfusion to limit infarct size and left ventricular remodelling in patients with acute coronary syndrome with ST segment elevation. Endpoints are infarct size measured by NMR and changes in left ventricular volume and ejection fraction.

3. Pain. Investigators at Wake Forest University are investigating Clonidine versus Adenosine to Treat Neuropathic Pain (www.clinicaltrials.gov identifier NCT00349921). Activation of adenosine receptors has been shown to inhibit pain via $A_{1}$ receptors in the spine (Borghi et al., 2002; Hussey et al., 2007) or secondary to inhibiting inflammation as a consequence of $\mathrm{A}_{2 \mathrm{~A}} \mathrm{R}$ activation. The purpose of this study is to compare the effects of intrathecal clonidine and adenosine on neuropathic thermal pain. Another pain study was conducted by Xsira Pharmaceuticals (Morrisville, NC) entitled Dose Response of Adenosine for Perioperative Pain (www.clinicaltrials.gov identifier NCT00298636). This was a dose-response trial of intravenous adenosine for perioperative analgesia in women undergoing abdominal hysterectomy or myomectomy.

\section{B. Dipyridamole}

The therapeutic use of adenosine is limited by its very short half-life in vivo. Dipyridamole continues to be investigated as an agent that can elevate adenosine levels for several hours as a result of its activity as an inhibitor of the equilibrative nucleoside transporter.

1. Coronary Vasodilation. Investigators at Hillel Yaffe Medical Center are exploring "Normal Coronary Artery" with Slow Flow Improved by Adenosine Injection, Dipyridamole Treatment, and Clinical Follow-up (www.clinicaltrials.gov identifier NCT00960817). Patients undergoing coronary angiography with normal coronary but slow blood flow that was normalized after adenosine injection into the coronary artery will be selected for this study. The investigators believe that these patients have small-vessel coronary disease that precedes anatomical narrowing of large vessels. To alleviate this phenomenon, the investigators will examine the long-term clinical response to treatment with dipyridamole. 
2. Schizophrenia. Investigators at the University of Maryland are conducting a Clinical Trial of Dipyridamole in Schizophrenia (www.clinicaltrials.gov identifier NCT00349973). In the central nervous system, adenosine signaling through $\mathrm{A}_{2 \mathrm{~A}}$ receptors generally counteracts dopamine signaling. Published data suggest efficacy of dipyridamole in treating psychosis when added to haloperidol treatment. This trial will test oral dipyridamole in symptomatic patients with a Diagnostic and Statistical Manual of Mental Disorders (American Psychiatric Association, 1994) diagnosis of schizophrenia, schizoaffective disorder, or schizophreniform disorder. The study aims to provide preliminary estimates of whether the effect sizes of dipyridamole on positive symptoms, negative symptoms, and cognitive deficits differ between patients with schizophrenia treated with dipyridamole and those treated with olanzapine.

\section{Synthetic Adenosine Receptor Agonists}

A number of synthetic agonists for the adenosine receptors have been or are being evaluated in clinical studies.

1. $A_{1}$ Partial Agonists. $\mathrm{A}_{1}$ agonists have the potential to produce heart block by effects on cardiomyocytes, reduce pain by effects on neurons in the spine, and inhibit lipolysis by effects on adipocytes. Partial agonists are being investigated in an attempt to influence pain and lipolysis without producing heart block.

a. GW493838 (5). Investigators at GlaxoSmithKline designed The Study of GW493838, an Adenosine $A_{1}$ Agonist, in Peripheral Neuropathic Pain (www. clinicaltrials.gov identifier NCT00376454). The purpose of this study was to determine the analgesic effect of GW493838 in patients with postherpetic neuralgia or peripheral nerve injury caused by trauma or surgery.

b. GS9667 (14). Investigators at Gilead Sciences are investigating this partial $\mathrm{A}_{1}$ agonist as a possible treatment for hypertriglyceridemia associated with diabetes.

c. Capadenoson (15). Bayer Schering Pharma is in phase II for the treatment of atrial fibrillation (www. clinicaltrials.gov identifier NCT00568945).

2. $A_{2 A}$ Agonists. Clinical uses of $\mathrm{A}_{2 \mathrm{~A}}$ agonists exploit the effects of $\mathrm{A}_{2 \mathrm{~A}}$ receptor activation to produce vasodilation and to reduce inflammation by activating receptors on several cells of the immune system.

a. Regadenoson (22). In 2008, the Food and Drug Administration approved Regadenoson (CVT 3146) for stress testing in conjunction with myocardial perfusion imaging (Al Jaroudi and Iskandrian, 2009). The side effects of regadenoson are similar to adenosine, but unlike adenosine, which is infused in the coronary artery, regadenoson can be given as an intravenous bolus. Apadenoson is currently in phase III clinical trails for the same indication. In phase II clinical trials, apade- noson displayed a much improved side-effect profile compared with adenosine.

b. BVT.115959. Biovitrum has completed a clinical trial entitled Efficacy and Tolerability of Novel $A_{2 A}$ Agonist in Treatment of Diabetic Neuropathic Pain (www. clinicaltrials.gov identifier NCT00452777). The purpose of this study was to evaluate the efficacy and tolerability of BVT.115959 in patients with diabetes with neuropathic pain.

3. $A_{3}$ Agonists. $\mathrm{A}_{3}$ receptors have been found to be highly expressed on some tumors and activated neutrophils (Ohaion et al., 2009; Varani et al., 2010, 2011). The physiology of $\mathrm{A}_{3}$ signaling is especially complex because of major differences between rodent and primate species in receptor function and tissue distribution. Orally active agonists are being tested in inflammatory diseases such as psoriasis and rheumatoid arthritis, and in cancer, and efficacy has been demonstrated in phase II trial for dry eye disease (Avni et al., 2010).

a. CF101 (25). Investigators at Can-Fite BioPharma have designed Oral CF101 Tablets Treatment in Patients with Rheumatoid Arthritis (www.clinicaltrials.gov identifier NCT00556894). This trial tested the hypothesis that the administration of IB-MECA (CF101) reduces inflammation in patients with rheumatoid arthritis. In the Safety and Efficacy of Daily CF101 Administered Orally in Subjects with Elevated Intraocular Pressure (www.clinicaltrials.gov identifier NCT01033422) study, treatment will be with CF101 or placebo for 16 weeks in a phase II trial to test the hypothesis that CF101, administered orally, will reduce intraocular pressure in patients with ocular hypertension and/or glaucoma. The Trial of CF101 to Treat Patients with Dry Eye Disease (www.clinicaltrials.gov identifier NCT01235234) will involved treatment with CF101 or placebo for 24 weeks in a phase III trial. Disease activity will be assessed using evaluations of ocular surface integrity, tear production, and patient symptoms.

b. CF102 (26). A Phase 1-2 Study of CF102, an $A_{3}$ Agonist, in Patients with Advanced Hepatocellular Carcinoma (www.clinicaltrials.gov identifier NCT00790218) will test the safety and efficacy of CF102 (Cl-IB-MECA) in patients with advanced liver cancer. Successive groups of patients will be given higher doses of CF102 by mouth on a twice-daily basis. Treatment will be assessed for adverse effects and for effects on the tumor. A Phase 1-2 Study of CF102 in Patients with Chronic Hepatitis C Genotype 1 (www.clinicaltrials.gov identifier NCT00790673) will test the hypothesis that CF102 can safely and effectively suppress viral load in patients with chronic hepatitis C and high circulating levels of virus. The trial will monitor the safety of twice-daily oral dosing with CF102 over a 16 -week period, will measure changes in viral load during therapy, and will measure blood concentrations of CF102 at various time points during dosing. 


\section{Adenosine Receptor Antagonists}

The approved methylxanthines theophylline, aminophylline (theophylline ethylenediamine), and caffeine are all nonselective adenosine receptor antagonists that are being used to investigate the consequences of adenosine receptor signaling in man.

1. Caffeine. Investigators at Radboud University/ The Netherlands Organization for Health Research and Development evaluated The Effect of Caffeine on Ischemic Preconditioning (www.clinicaltrials.gov identifier NCT00184912). Brief periods of ischemia render the myocardium more resistant to a subsequent more prolonged period of ischemia and reperfusion. This phenomenon is referred to as ischemic preconditioning. Animal studies have provided evidence that adenosine receptor stimulation is an important mediator of ischemic preconditioning. Because caffeine is an effective adenosine receptor antagonist at concentrations reached after coffee consumption, this study showed that caffeine impairs preconditioning in humans in vivo as assessed using ${ }^{99 \mathrm{~m}}$ Tc-annexin A5 scintigraphy in forearm skeletal muscle (Riksen et al., 2006).

Investigators at McMaster University have designed the Caffeine for Apnea of Prematurity-Sleep (CAP-S) Study (www.clinicaltrials.gov identifier NCT01020357). Apnea of prematurity is a common condition that is usually treated with methylxanthines. Little is known about the long-term effects of methylxanthines on the developing brain. This is a placebo-controlled randomized trial of methylxanthine therapy for apnea of prematurity. This substudy is designed to take advantage of a cohort of ex-premature 5 -to 7-year-old children who were randomized at birth to receive either caffeine or placebo and are currently receiving detailed neurocognitive and behavioral assessments in the CAP trial.

2. Aminophylline. Investigators at King Faisal University investigated Aminophylline for Entropy Recovery after Sevoflurane Anaesthesia (www.clinicaltrials.gov identifier NCT01022151). The use of general anesthesia in fast-tracking outpatient setting represents a great challenge because the residual anesthetic effects may delay home discharge after surgery. Sevoflurane has been advocated for the routine anesthesia for ambulatory surgery patients. Sevoflurane activates adenosine $\mathrm{A}_{1}$ receptors in primary rat hippocampal cultures through the liberation of adenosine secondary to the interaction with adenosine transporters or key enzymes in adenosine metabolism. Aminophylline in doses of 3 to $5 \mathrm{mg} / \mathrm{kg}$ hastens recovery from sevoflurane anesthesia and improves bispectral index scores with associated significant increases in heart rate. This study investigates the use of lower doses of aminophylline $(2-3 \mathrm{mg} /$ $\mathrm{kg}$ ) to hasten the recovery from sevoflurane anesthesia with the possible avoidance of significant tachycardia.

3. Selective $A_{1}$ Antagonists. Preglomerular arterioles in the kidney are unusual in that they constrict in re- sponse to adenosine $A_{1}$ receptor activation. Several companies are evaluating $A_{1}$ antagonists as diuretics.

a. Rolofylline (37). Investigators at NovaCardia and Merck have designed PROTECT-2: A Study of the Selective $A_{1}$ Adenosine Receptor Antagonist KW-3902 for Patients Hospitalized with Acute HF and Volume Overload to Assess Treatment Effect on Congestion and Renal Function. This study demonstrated that rolofylline [1,3dipropyl-8-(3-noradamantyl)xanthine (KW-3902)] administered intravenously resulted in improvement in signs and symptoms of heart failure, with less treatment failure than standard therapy (Cotter et al., 2008). However, PROTECT-2 did not demonstrate clinical efficacy.

Other $\mathrm{A}_{1}$ antagonists being investigated for this indication include trans-4-[(2-phenyl-7H-pyrrolo[2,3- $d]$ pyrimidin-4-yl)amino]cyclohexanol [SLV320 (41); Abbott Laboratories] and 3-(4-(2,6-dioxo-1,3-dipropyl-2,3,6,7-tetrahydro$1 H$-purin-8-yl)-bicyclo(2.20.2)oct-1-yl)propionic acid [BG9928 (39); tonapofylline; Biogen ldec, Weston, MA], but the negative outcome in PROTECT-2 may influence their fate.

4. Selective $A_{2 A}$ Antagonists. Selective $\mathrm{A}_{2 \mathrm{~A}}$ blockers are being evaluated for the treatment of Parkinson's disease and for drug addiction on the basis of these compounds' ability to simulate activation of dopamine $\mathrm{D}_{2}$ receptors (Svenningsson et al., 1999; Jenner et al., 2009; Pinna, 2009). The selective $\mathrm{A}_{2 \mathrm{~A}}$ antagonists $(\boldsymbol{E})$-1,3-diethyl-8-( $m, p$-dimethoxystyryl)xanthine [KW6002 (43); istradefylline; Kyowa-Hakko Kogyo, Tokyo, Japan] has been extensively studied in large phase III studies (Hauser et al., 2008; LeWitt et al., 2008; Stacy et al., 2008) Other antagonists including vipadenant [BIIB014 (47), V2006; Vernalis and Biogen-Idec], SCH442416 (52), preladenant [SCH-420814 (51); Schering Plough, Kenilworth, NJ], and ST-1535 (49) have been in phase I and II clinical trials for Parkinson's disease. Vipadenant and preladenant are effective in reducing the waking time during the Off state in patients with late-stage Parkinson's disease who are receiving L-DOPA. Vipadenant is also an effective monotherapy during the early stages of Parkinson's disease, but its development has been stopped because of preclinical toxicological issues.

Investigators at the National Institute on Drug Abuse are conducting An fMRI Study of SYN115 in Cocaine Dependent Subjects (www.clinicaltrials.gov identifier NCT00783276). The dopamine system is critical in modulation of reward and has been implicated in the initiation and maintenance of addiction. Medications that increase dopamine either directly or indirectly may have efficacy at reducing cocaine use in cocaine dependent subjects. This study examines the acute effects of $\mathrm{A}_{2 \mathrm{~A}}$ receptor antagonist 4-hydroxy-4methyl-piperidine-1-carboxylic acid-(4-methoxy-7morpholin-4-yl-benzothiazol-2-yl)-amide (SYN115; 44) (Synosia Therapeutics, Basel, Switzerland) on brain function and behavior in cocaine-dependent subjects with the use of functional magnetic resonance imaging. 
5. Selective $A_{2 B}$ Antagonists. $\mathrm{A}_{2 \mathrm{~B}}$ receptor blockers inhibit the degranulation of activated human mast cells and the release of cytokines for several other cell types. In addition, $\mathrm{A}_{2 \mathrm{~B}}$ blockade reverses insulin resistance in animal models of type II diabetes. Hence, $\mathrm{A}_{2 \mathrm{~B}}$ blockers are in development for the treatment of asthma and diabetes. A selective $\mathrm{A}_{2 \mathrm{~B}}$ antagonist is being developed in a partnership between Clinical Data, Inc. (Newton, MA) and Novartis (Basel, Switzerland). GS 6201 [CVT-6883 (56)] is being developed by Gilead Sciences (Foster City, CA).

Thus, there are several recent interesting developments in the efforts to bring adenosine-receptor directed drugs to the clinic.

\section{Concluding Remarks}

Adenosine receptors constitute one of the best studied and characterized subfamilies of 7TM receptors. The physiological roles have been examined in vivo and in vitro using both genetic and pharmacological tools. There are rather good agonists and antagonists for all four receptors. There is evidence that adenosine receptors are potential drug targets in several areas, and several clinical studies are ongoing. The fact that adenosine receptors influence a large number of processes, both physiological and pathological, introduces a measure of caution regarding widespread long-term use. Conversely, the widespread consumption of caffeine in doses that do block adenosine receptors, with few apparent negative consequences, argues that adenosine receptors can be targeted.

The following are among the more important open pharmacological questions:

- How are the levels of adenosine regulated in different tissues and different conditions (physiological and pathological)?

- What is the functional significance of multimeric (homomeric or heteromeric) adenosine receptors? Do they offer pharmacological opportunities?

- Do all antagonists bind to the same states and sites? Are there major differences between receptors?

- Is it possible to tap into the potential for specificity offered by allosteric ligands or partial agonists?

- What will happen in the several clinical trials?

- Should drugs targeting adenosine receptors be used alone or as adjuvant to other therapies?

\section{Acknowledgments}

This work was supported by the Swedish Science Council [Project 2553] (to B.B.F.); the Dutch Top Institute Pharma [Project D1-105] (to A.P.IJ.); by the Intramural Research Program of the National Institutes of Health National Institute of Diabetes and Digestive and Kidney Diseases (to K.A.J.); and the Bundesministerium für Bildung und Forschung within the BioPharma-Neuroallianz project (to C.E.M.).

\section{Authorship Contributions}

Wrote or contributed to the writing of the manuscript: Fredholm, IJzerman, Jacobson, Linden, and Müller.

\section{References}

Abo-Salem OM, Hayallah AM, Bilkei-Gorzo A, Filipek B, Zimmer A, and Müller CE (2004) Antinociceptive effects of novel $\mathrm{A}_{2 \mathrm{~B}}$ adenosine receptor antagonists. J Pharmacol Exp Ther 308:358-366.

Al Jaroudi W and Iskandrian AE (2009) Regadenoson: a new myocardial stress agent. J Am Coll Cardiol 54:1123-1130.

Alsene K, Deckert J, Sand P, and de Wit H (2003) Association between A2a receptor gene polymorphisms and caffeine-induced anxiety. Neuropsychopharmacology 28: 1694-1702.

American Psychiatric Association (1994) Diagnostic and Statistical Manual of Mental Disorders, 4th ed. American Psychiatric Association, Arlington, VA.

Arslan G, Kull B, and Fredholm BB (1999) Signaling via $\mathrm{A}_{2 \mathrm{~A}}$ adenosine receptor in four PC12 cell clones. Naunyn Schmiedebergs Arch Pharmacol 359:28-32.

Auchampach JA, Jin X, Wan TC, Caughey GH, and Linden J (1997) Canine mast cell adenosine receptors: cloning and expression of the $\mathrm{A}_{3}$ receptor and evidence that degranulation is mediated by the $\mathrm{A}_{2 \mathrm{~B}}$ receptor. Mol Pharmacol 52:846-860.

Auchampach JA, Kreckler LM, Wan TC, Maas JE, van der Hoeven D, Gizewski E, Narayanan J, and Maas GE (2009) Characterization of the $\mathrm{A}_{2 \mathrm{~B}}$ adenosine receptor from mouse, rabbit, and dog. J Pharmacol Exp Ther 329:2-13.

Aurelio L, Valant C, Flynn BL, Sexton PM, Christopoulos A, and Scammells PJ (2009) Allosteric modulators of the adenosine $\mathrm{A}_{1}$ receptor: synthesis and pharmacological evaluation of 4-substituted 2-amino-3-benzoylthiophenes. J Med Chem 52:4543-4547.

Avni I, Garzozi HJ, Barequet IS, Segev F, Varssano D, Sartani G, Chetrit N, Bakshi E, Zadok D, Tomkins O, et al. (2010) Treatment of dry eye syndrome with orallyadministered CF101: data from a phase 2 clinical trial. Ophthalmology 117:12871293.

Ballarín M, Fredholm BB, Ambrosio S, and Mahy N (1991) Extracellular levels of adenosine and its metabolites in the striatum of awake rats: inhibition of uptake and metabolism. Acta Physiol Scand 142:97-103.

Baraldi PG, Iaconinoto MA, Moorman AR, Carrion MD, Cara CL, Preti D, López OC, Fruttarolo F, Tabrizi MA, and Romagnoli R (2007a) Allosteric enhancers for $\mathrm{A}_{1}$ adenosine receptor. Mini Rev Med Chem 7:559-569.

Baraldi PG, Pavani MG, Leung E, Moorman AR, Varani K, Vincenzi F, Borea PA, and Romagnoli $R$ (2006) Synthesis and biological characterization of $\left[{ }^{3} \mathrm{H}\right](2$-amino4,5,6,7-tetrahydrobenzo[b]thiophen-3-yl)-(4-chlorophenyl)-methanone, the first radiolabelled adenosine $\mathrm{A}_{1}$ allosteric enhancer. Bioorg Med Chem Lett 16:14021404.

Baraldi PG, Preti D, Tabrizi MA, Fruttarolo F, Romagnoli R, Carrion MD, Cara LC, Moorman AR, Varani K, and Borea PA (2007b) Synthesis and biological evaluation of novel 1-deoxy-1-[6-[((hetero)arylcarbonyl)hydrazine]-9H-purin-9-yl]- $N$-ethyl- $\beta$ D-ribofuranuronamide derivatives as useful templates for the development of $\mathrm{A}_{2 \mathrm{~B}}$ adenosine receptor agonists. $J$ Med Chem 50:374-380.

Baraldi PG, Tabrizi MA, Preti D, Bovero A, Romagnoli R, Fruttarolo F, Zaid NA, Moorman AR, Varani K, Gessi S, et al. (2004) Design, synthesis, and biological evaluation of new 8-heterocyclic xanthine derivatives as highly potent and selective human $\mathrm{A}_{2 \mathrm{~B}}$ adenosine receptor antagonists. J Med Chem 47:1434-1447.

Baraldi PG, Zaid AN, Lampronti I, Fruttarolo F, Pavani MG, Tabrizi MA, Shryock JC, Leung E, and Romagnoli R (2000) Synthesis and biological effects of a new series of 2-amino-3-benzoylthiophenes as allosteric enhancers of $\mathrm{A}_{1}$ adenosine receptor. Bioorg Med Chem Lett 10:1953-1957.

Barbhaiya H, McClain R, IJzerman A, and Rivkees SA (1996) Site-directed mutagenesis of the human $A_{1}$ adenosine receptor: influences of acidic and hydroxy residues int he first four transmembrane domains on ligand binding. Mol Pharmacol 50:1635-1642.

Bastia E, Xu YH, Scibelli AC, Day YJ, Linden J, Chen JF, and Schwarzschild MA (2005) A crucial role for forebrain adenosine $\mathrm{A}(2 \mathrm{~A})$ receptors in amphetamine sensitization. Neuropsychopharmacology 30:891-900.

Bertarelli DC, Diekmann M, Hayallah AM, Rüsing D, Iqbal J, Preiss B, Verspohl EJ, and Müller CE (2006) Characterization of human and rodent native and recombinant adenosine $\mathrm{A}_{2 \mathrm{~B}}$ receptors by radioligand binding studies. Purinergic Signal 2:559-571.

Beukers MW, Chang LC, von Frijtag Drabbe Künzel JK, Mulder-Krieger T, Spanjersberg RF, Brussee J, and IJzerman AP (2004) New, non-adenosine, highpotency agonists for the human adenosine $\mathrm{A}_{2 \mathrm{~B}}$ receptor with an improved selectivity profile compared to the reference agonist N-ethylcarboxamidoadenosine. J Med Chem 47:3707-3709.

Beukers MW, Wanner MJ, Von Frijtag Drabbe Künzel JK, Klaasse EC, IJzerman AP, and Koomen GJ (2003) $N^{6}$-Cyclopentyl-2-(3-phenylaminocarbonyltriazene-1yl)adenosine (TCPA), a very selective agonist with high affinity for the human adenosine $\mathrm{A}_{1}$ receptor. J Med Chem 46:1492-1503.

Björklund O, Kahlström J, Salmi P, and Fredholm BB (2008) Perinatal caffeine, acting on maternal adenosine $\mathrm{A} 1$ receptors, causes long-lasting behavioral changes in mouse offspring. PloS One 3:e3977.

Bhattacharya S, Youkey RL, Ghartey K, Leonard M, Linden J, and Tucker AL (2006) The allosteric enhancer PD 81,723 increases chimaeric $\mathrm{A}_{1} / \mathrm{A}_{2 \mathrm{~A}}$ adenosine receptor coupling with Gs. Biochem J 396:139-146.

Blackburn MR, Datta SK, and Kellems RE (1998) Adenosine deaminase-deficient mice generated using a two-stage genetic engineering strategy exhibit a combined immunodeficiency. J Biol Chem 273:5093-5100.

Boison D, Scheurer L, Zumsteg V, Rülicke T, Litynski P, Fowler B, Brandner S, and Mohler H (2002) Neonatal hepatic steatosis by disruption of the adenosine kinase gene. Proc Natl Acad Sci USA 99:6985-6990.

Borghi V, Przewlocka B, Labuz D, Maj M, Ilona O, and Pavone F (2002) Formalin- 
induced pain and mu-opioid receptor density in brain and spinal cord are modulated by $\mathrm{A} 1$ and $\mathrm{A} 2 \mathrm{a}$ adenosine agonists in mice. Brain Res 956:339-348.

Borrmann T, Hinz S, Bertarelli DC, Li W, Florin NC, Scheiff AB, and Müller CE (2009) 1-Alkyl-8-(piperazine-1-sulfonyl)phenylxanthines: development and characterization of adenosine $\mathrm{A}_{2 \mathrm{~B}}$ receptor antagonists and a new radioligand with subnanomolar affinity and subtype specificity. J Med Chem 52:3994-4006.

Brackett LE and Daly JW (1994) Functional characterization of the A2b adenosine receptor in NIH 3T3 fibroblasts. Biochem Pharmacol 47:801-814.

Briddon SJ, Gandía J, Amaral OB, Ferré S, Lluís C, Franco R, Hill SJ, and Ciruela $\mathrm{F}$ (2008) Plasma membrane diffusion of $\mathrm{G}$ protein-coupled receptor oligomers. Biochim Biophys Acta 1783:2262-2268.

Brown R, Ollerstam A, Johansson B, Skøtt O, Gebre-Medhin S, Fredholm B, and Persson AE (2001) Abolished tubuloglomerular feedback and increased plasma renin in adenosine $\mathrm{A} 1$ receptor-deficient mice. Am J Physiol Regul Integr Comp Physiol 281:R1362-R1367.

Bruns RF (1980) Adenosine receptor activation in human fibroblasts: nucleoside agonists and antagonists. Can J Physiol Pharmacol 58:673-691.

Bruns RF, Fergus JH, Coughenour LL, Courtland GG, Pugsley TA, Dodd JH, and Tinney FJ (1990) Structure-activity relationships for enhancement of adenosine $A_{1}$ receptor binding by 2-amino-3-benzoylthiophenes. Mol Pharmacol 38:950-958.

Burnstock G (2006) Historical review: ATP as a neurotransmitter. Trends Pharmacol Sci 27:166-176.

Cabello N, Gandía J, Bertarelli DC, Watanabe M, Lluís C, Franco R, Ferré S, Luján $\mathrm{R}$, and Ciruela F (2009) Metabotropic glutamate type 5, dopamine $\mathrm{D}_{2}$ and adenosine $\mathrm{A}_{2 \mathrm{~A}}$ receptors form higher-order oligomers in living cells. J Neurochem 109: 1497-1507.

Cagnina RE, Ramos SI, Marshall MA, Wang G, Frazier CR, and Linden J (2009) Adenosine A2B receptors are highly expressed on murine type II alveolar epithelial cells. Am J Physiol Lung Cell Mol Physiol 297:L467-L474.

Canals M, Burgueño J, Marcellino D, Cabello N, Canela EI, Mallol J, Agnati L, Ferré S, Bouvier M, Fuxe K, et al. (2004) Homodimerization of adenosine $\mathrm{A}_{2 \mathrm{~A}}$ receptors: qualitative and quantitative assessment by fluorescence and bioluminescence energy transfer. $J$ Neurochem 88:726-734.

Canals M, Marcellino D, Fanelli F, Ciruela F, de Benedetti P, Goldberg SR, Neve K, Fuxe K, Agnati LF, Woods AS, et al. (2003) Adenosine $\mathrm{A}_{2 \mathrm{~A}}$-dopamine $\mathrm{D}_{2}$ receptorreceptor heteromerization: qualitative and quantitative assessment by fluorescence and bioluminescence energy transfer. J Biol Chem 278:46741-46749.

Carlsson J, Yoo L, Gao ZG, Irwin JJ, Shoichet BK, and Jacobson KA (2010) Structure-based discovery of $\mathrm{A}_{2 \mathrm{~A}}$ adenosine receptor ligands. J Med Chem 53:37483755 .

Carriba P, Navarro G, Ciruela F, Ferré S, Casadó V, Agnati L, Cortés A, Mallol J, Fuxe K, Canela EI, et al. (2008) Detection of heteromerization of more than two proteins by sequential BRET-FRET. Nat Methods 5:727-733.

Carriba P, Ortiz O, Patkar K, Justinova Z, Stroik J, Themann A, Müller C, Woods AS, Hope BT, Ciruela F, et al. (2007) Striatal adenosine $A_{2 A}$ and cannabinoid $\mathrm{CB}_{1}$ receptors form functional heteromeric complexes that mediate the motor effects of cannabinoids. Neuropsychopharmacology 32:2249-2259.

Chabre M and le Maire M (2005) Monomeric G-protein-coupled receptor as a functional unit. Biochemistry 44:9395-9403.

Chabre M, Deterre P, and Antonny B. (2009) The apparent cooperativity of some GPCRs does not necessarily imply dimerization. Trends Pharmacol Sci 30:182187.

Chang LC, von Frijtag Drabbe Künzel JK, Mulder-Krieger T, Spanjersberg RF, Roerink SF, van den Hout G, Beukers MW, Brussee J, and IJzerman AP (2005) A series of ligands displaying a remarkable agonistic-antagonistic profile at the adenosine $\mathrm{A}_{1}$ receptor. J Med Chem 48:2045-2053.

Chang LC, von Frijtag Drabbe Künzel JK, Mulder-Krieger T, Westerhout J, Spangenberg T, Brussee J, and IJzerman AP (2007) 2,6,8-trisubstituted 1-deazapurines as adenosine receptor antagonists. $J$ Med Chem 50:828-834.

Chen JF, Beilstein M, Xu YH, Turner TJ, Moratalla R, Standaert DG, Aloyo VJ, Fink JS, and Schwarzschild MA (2000) Selective attenuation of psychostimulantinduced behavioral responses in mice lacking $\mathrm{A}_{2 \mathrm{~A}}$ adenosine receptors. Neuroscience 97:195-204.

Chen JF, Huang Z, Ma J, Zhu J, Moratalla R, Standaert D, Moskowitz MA, Fink JS, and Schwarzschild MA (1999) $\mathrm{A}_{2 \mathrm{~A}}$ adenosine receptor deficiency attenuates brain injury induced by transient focal ischemia in mice. J Neurosci 19:9192-9200.

Chen JF, Moratalla R, Impagnatiello F, Grandy DK, Cuellar B, Rubinstein M, Beilstein MA, Hackett E, Fink JS, Low MJ, et al. (2001a) The role of the D(2) dopamine receptor $(\mathrm{D}(2) \mathrm{R})$ in $\mathrm{A}(2 \mathrm{~A})$ adenosine receptor $\left(\mathrm{A}_{2 \mathrm{~A}} \mathrm{R}\right)$-mediated behavioral and cellular responses as revealed by $\mathrm{A}_{2 \mathrm{~A}}$ and $\mathrm{D}_{2}$ receptor knockout mice. Proc Natl Acad Sci USA 98:1970-1975.

Chen JF, Sonsalla PK, Pedata F, Melani A, Domenici MR, Popoli P, Geiger J, Lopes LV, and de Mendonça A (2007) Adenosine $A_{2 A}$ receptors and brain injury: broad spectrum of neuroprotection, multifaceted actions and "fine tuning" modulation. Prog Neurobiol 83:310-331.

Chen JF, Xu K, Petzer JP, Staal R, Xu YH, Beilstein M, Sonsalla PK, Castagnoli K, Castagnoli N Jr, and Schwarzschild MA (2001b) Neuroprotection by caffeine and $\mathrm{A}(2 \mathrm{~A})$ adenosine receptor inactivation in a model of Parkinson's disease. J Neurosci 21:RC143.

Chen Y, Corriden R, Inoue Y, Yip L, Hashiguchi N, Zinkernagel A, Nizet V, Insel PA, and Junger WG (2006) ATP release guides neutrophil chemotaxis via P2Y2 and A3 receptors. Science 314:1792-1795.

Childs E, Hohoff C, Deckert J, Xu K, Badner J, and de Wit H (2008) Association between ADORA2A and DRD2 polymorphisms and caffeine-induced anxiety. Neuropsychopharmacology 33:2791-2800.

Chordia MD, Zigler M, Murphree LJ, Figler H, Macdonald TL, Olsson RA, and Linden $J$ (2005) 6-aryl-8H-indeno[1,2-d] thiazol-2-ylamines: $\mathrm{A}_{1}$ adenosine receptor agonist allosteric enhancers having improved potency. J Med Chem 48:5131-5139.

Ciruela F, Casadó V, Mallol J, Canela EI, Lluis C, and Franco R (1995) Immunological identification of $\mathrm{A}_{1}$ adenosine receptors in brain cortex. $J$ Neurosci Res 42: $818-828$.
Ciruela F, Casadó V, Rodrigues RJ, Luján R, Burgueño J, Canals M, Borycz J, Rebola N, Goldberg SR, Mallol J, et al. (2006) Presynaptic control of striatal glutamatergic neurotransmission by adenosine $\mathrm{A}_{1}-\mathrm{A}_{2 \mathrm{~A}}$ receptor heteromers. J Neurosci 26:2080 2087

Cohen FR, Lazareno S, and Birdsall NJ (1996) The affinity of adenosine for the highand low-affinity states of the human adenosine A1 receptor. Eur J Pharmacol 309:111-114.

Conn PJ, Christopoulos A, and Lindsley CW (2009) Allosteric modulators of GPCRs: a novel approach for the treatment of CNS disorders. Nat Rev Drug Discov 8:41-54.

Cotter G, Dittrich HC, Weatherley BD, Bloomfield DM, O'Connor CM, Metra M, Massie BM, Protect Steering Committee, Investigators, and and Coordinators (2008) The PROTECT pilot study: a randomized, placebo-controlled, dose-finding study of the adenosine $A_{1}$ receptor antagonist rolofylline in patients with acute heart failure and renal impairment. J Card Fail 14:631-640.

Daly JW, Hide I, Müller CE, and Shamim M (1991) Caffeine analogs: structureactivity relationships at adenosine receptors. Pharmacology 42:309-321.

Daly JW, Padgett WL, Secunda SI, Thompson RD, and Olsson RA (1993) Structureactivity relationships for 2 -substituted adenosines at A1 and A2 adenosine receptors. Pharmacology 46:91-100.

Daly JW and Jacobson KA (1995) Adenosine and Andenine Nucleotides: from Molecular Biology to Integrative Physiology, Kluwer Academic Publishers, Boston.

Deckert J, Nöthen MM, Franke P, Delmo C, Fritze J, Knapp M, Maier W, Beckmann $\mathrm{H}$, and Propping P (1998) Systematic mutation screening and association study of the $\mathrm{A}_{1}$ and $\mathrm{A}_{2 \mathrm{a}}$ adenosine receptor genes in panic disorder suggest a contribution of the $\mathrm{A}_{2 \mathrm{a}}$ gene to the development of disease. Mol Psychiatry 3:81-85.

de Ligt RA, Rivkees SA, Lorenzen A, Leurs R, and IJzerman AP (2005) A "locked-on," constitutively active mutant of the adenosine $\mathrm{A}_{1}$ receptor. Eur $J$ Pharmacol 510:1-8.

Doggrell SA (2005) BG-9928 (Biogen Idec). Curr Opin Investig Drugs 6:962-968.

Eastwood P, Gonzalez J, Paredes S, Nueda A, Domenech T, Alberti J, and Vidal B (2010) Discovery of $N$-(5,6-diarylpyridin-2-yl)amide derivatives as potent and selective $\mathrm{A}_{2 \mathrm{~B}}$ adenosine receptor antagonists. Bioorg Med Chem Lett 20:1697-1700

Eckle T, Krahn T, Grenz A, Köhler D, Mittelbronn M, Ledent C, Jacobson MA, Osswald H, Thompson LF, Unertl K, et al. (2007) Cardioprotection by ecto-5' nucleotidase (CD73) and $\mathrm{A}_{2 \mathrm{~B}}$ adenosine receptors. Circulation 115:1581-1590.

Elliott MR, Chekeni FB, Trampont PC, Lazarowski ER, Kadl A, Walk SF, Park D, Woodson RI, Ostankovich M, Sharma P, et al. (2009) Nucleotides released by apoptotic cells act as a find-me signal to promote phagocytic clearance. Nature 461:282-286.

Elzein E, Kalla RV, Li X, Perry T, Gimbel A, Zeng D, Lustig D, Leung K, and Zablocki $\mathrm{J}$ (2008) Discovery of a novel $\mathrm{A}_{2 \mathrm{~B}}$ adenosine receptor antagonist as a clinical candidate for chronic inflammatory airway diseases. J Med Chem 51:2267-2278

Elzein E and Zablocki J (2008) $\mathrm{A}_{1}$ adenosine receptor agonists and their potential therapeutic applications. Expert Opin Investig Drugs 17:1901-1910.

El Yacoubi M, Ledent C, Ménard JF, Parmentier M, Costentin J, and Vaugeois JM (2000) The stimulant effects of caffeine on locomotor behaviour in mice are mediated through its blockade of adenosine $\mathrm{A}(2 \mathrm{~A})$ receptors. Br J Pharmacol 129:14651473

Enjyoji K, Sévigny J, Lin Y, Frenette PS, Christie PD, Esch JS 2nd, Imai M, Edelberg JM, Rayburn H, Lech M, et al. (1999) Targeted disruption of cd39/ATP diphosphohydrolase results in disordered hemostasis and thromboregulation. Nat Med 5:1010-1017.

Fedele DE, Li T, Lan JQ, Fredholm BB, and Boison D (2006) Adenosine A(1) receptors are crucial in keeping an epileptic focus localized. Exp Neurol 200:184190.

Ferré S, Baler R, Bouvier M, Caron MG, Devi LA, Durroux T, Fuxe K, George SR, Javitch JA, Lohse MJ, et al. (2009) Building a new conceptual framework for receptor heteromers. Nat Chem Biol 5:131-134.

Ferré S, Torvinen M, Antoniou K, Irenius E, Civelli O, Arenas E, Fredholm BB, and Fuxe K (1998) Adenosine $A_{1}$ receptor-mediated modulation of dopamine $D_{1}$ receptors in stably cotransfected fibroblast cells. J Biol Chem 273:4718-4724.

Fozard JR, Baur F, and Wolber C (2003) Antagonist pharmacology of adenosine $A_{2 B}$ receptors from rat, guinea pig and dog. Eur J Pharmacol 475:79-84.

Franchetti P, Cappellacci L, Marchetti S, Trincavelli L, Martini C, Mazzoni MR, Lucacchini A, and Grifantini M (1998) 2'-C-methyl analogues of selective adenosine receptor agonists: synthesis and binding studies. J Med Chem 41:1708-1715

Fredholm BB, Abbracchio MP, Burnstock G, Daly JW, Harden TK, Jacobson KA, Leff $\mathrm{P}$, and Williams M (1994) Nomenclature and classification of purinoceptors. Pharmacol Rev 46:143-156.

Fredholm BB, Chen JF, Masino SA, and Vaugeois JM (2005) Actions of adenosine at its receptors in the CNS: insights from knockouts and drugs. Annu Rev Pharmacol Toxicol 45:385-412.

Fredholm BB, IJzerman AP, Jacobson KA, Klotz KN, and Linden J (2001a) International Union of Pharmacology. XXV. Nomenclature and classification of adenosine receptors. Pharmacol Rev 53:527-552.

Fredholm BB, Irenius E, Kull B, and Schulte G (2001b) Comparison of the potency of adenosine as an agonist at human adenosine receptors expressed in Chinese hamster ovary cells. Biochem Pharmacol 61:443-448.

Gandia J, Galino J, Amaral OB, Soriano A, Lluís C, Franco R, and Ciruela F (2008) Detection of higher-order $\mathrm{G}$ protein-coupled receptor oligomers by a combined BRET-BiFC technique. FEBS Lett 582:2979-2984.

Gao ZG and IJzerman AP (2000) Allosteric modulation of $\mathrm{A}_{2 \mathrm{~A}}$ adenosine receptors by amiloride analogues and sodium ions. Biochem Pharmacol 60:669-676.

Gao ZG, Van Muijlwijk-Koezen JE, Chen A, Müller CE, IJzerman AP, and Jacobson KA (2001) Allosteric modulation of $\mathrm{A}_{3}$ adenosine receptors by a series of 3-(2pyridinyl)isoquinoline derivatives. Mol Pharmacol 60:1057-1063.

Gao ZG, Kim SG, Soltysiak KA, Melman N, IJzerman AP, and Jacobson KA (2002) Selective allosteric enhancement of agonist binding and function at human $\mathrm{A}_{3}$ adenosine receptors by a series of imidazoquinoline derivatives. Mol Pharmacol 62:81-89. 
Gao ZG, Kim SK, Gross AS, Chen A, Blaustein JB, and Jacobson KA (2003a) Identification of essential residues involved in the allosteric modulation of the human $\mathrm{A}_{3}$ adenosine receptor. Mol Pharmacol 63:1021-1031.

Gao ZG, Melman N, Erdmann A, Kim SG, Müller CE, IJzerman AP, and Jacobson KA (2003b) Differential allosteric modulation by amiloride analogues of agonist and antagonist binding at $\mathrm{A}_{1}$ and $\mathrm{A}_{3}$ adenosine receptors. Biochem Pharmacol 65:525-534.

Gao ZG, Kim SK, IJzerman AP, and Jacobson KA (2005) Allosteric modulation of the adenosine family of receptor. Mini Rev Med Chem 5:545-553.

Gao ZG, Ye K, Göblyös A, IJzerman AP, and Jacobson KA. (2008) Flexible modulation of agonist efficacy at the human A3 adenosine receptor by the imidazoquinoline allosteric enhancer LUF6000. BMC Pharmacol 8:20

Ge ZD, Peart JN, Kreckler LM, Wan TC, Jacobson MA, Gross GJ, and Auchampach JA (2006) Cl-IB-MECA [2-chloro- $N 6$-(3-iodobenzyl)adenosine-5'-N-methylcarboxamidel reduces ischemia/reperfusion injury in mice by activating the $\mathrm{A}_{3}$ adenosine receptor. J Pharmacol Exp Ther 319:1200-1210.

Gillespie RJ, Bamford SJ, Botting R, Comer M, Denny S, Gaur S, Griffin M, Jordan $\mathrm{AM}$, Knight AR, Lerpiniere J, et al. (2009) Antagonists of the human $\mathrm{A}_{2 \mathrm{~A}}$ receptor. 4. Design, synthesis, and preclinical evaluation of 7-aryltriazolo[4,5- $d$ ] pyrimidines. J Med Chem 52:33-47.

Ginés S, Hillion J, Torvinen M, Le Crom S, Casadó V, Canela EI, Rondin S, Lew JY, Watson S, Zoli M, et al. (2000) Dopamine $\mathrm{D}_{1}$ and adenosine $\mathrm{A}_{1}$ receptors form functionally interacting heteromeric complexes. Proc Natl Acad Sci USA 97:86068611.

Giorgi I, Biagi G, Bianucci AM, Borghini A, Livi O, Leonardi M, Pietra D, Calderone V, and Martelli A (2008) $\mathrm{N}^{6}$-1,3-diphenylurea derivatives of 2-phenyl-9 benzyladenines and 8-azaadenines: synthesis and biological evaluation as allosteric modulators of $\mathrm{A}_{2 \mathrm{~A}}$ adenosine receptors. Eur J Med Chem 43:1639-1647.

Göblyös A, Santiago SN, Pietra D, Mulder-Krieger T, von Frijtag Drabbe Künzel J, Brussee J, and IJzerman AP (2005) Synthesis and biological evaluation of 2-aminothiazoles and their amide derivatives on human adenosine receptors. Lack of effect of 2-aminothiazoles as allosteric enhancers. Bioorg Med Chem 13:20792087.

Göblyös A, Gao ZG, Brussee J, Connestari R, Santiago SN, Ye K, IJzerman AP, and Jacobson KA (2006) Structure activity relationships of $1 H$-imidazo[4,5-c]quinolin4 -amine derivatives new as allosteric enhancers of the $\mathrm{A}_{3}$ adenosine receptor. I Med Chem 49:3354-3361.

Goldman N, Chen M, Fujita T, Xu Q, Peng W, Liu W, Jensen TK, Pei Y, Wang F, Han $\mathrm{X}$, et al. (2010) Adenosine A1 receptors mediate local anti-nociceptive effects of acupuncture. Nat Neurosci 13:883-888.

Grahner B, Winiwarter S, Lanzner W, and Müller CE (1994) Synthesis and structure-activity relationships of deazaxanthines: analogs of potent $\mathrm{A}_{1^{-}}$and $\mathrm{A}_{2}$ adenosine receptor antagonists. J Med Chem 37:1526-1534.

Guo Y, Bolli R, Bao W, Wu WJ, Black RG, Jr., Murphree SS, Salvatore CA, Jacobson MA, and Auchampach JA (2001) Targeted deletion of the $\mathrm{A}_{3}$ adenosine receptor confers resistance to myocardial ischemic injury and does not prevent early preconditioning. J Mol Cell Cardiol 33:825-830.

Hamilton SP, Slager SL, De Leon AB, Heiman GA, Klein DF, Hodge SE, Weissman MM, Fyer AJ, and Knowles JA (2004) Evidence for genetic linkage between a polymorphism in the adenosine $2 \mathrm{~A}$ receptor and panic disorder. Neuropsychopharmacology 29:558-565.

Hauser RA, Shulman LM, Trugman JM, Roberts JW, Mori A, Ballerini R, Sussman NM, and Istradefylline 6002-US-013 Study Group (2008) Study of istradefylline in patients with Parkinson's disease on levodopa with motor fluctuations. Mov Disord 23:2177-2185.

Hayallah AM, Sandoval-Ramírez J, Reith U, Schobert U, Preiss B, Schumacher B, Daly JW, and Müller CE (2002) 1,8-Disubstituted xanthine derivatives: synthesis of potent $\mathrm{A}_{2 \mathrm{~B}}$-selective adenosine receptor antagonists. J Med Chem 45:15001510 .

Heitman LH, Göblyös A, Zweemer AM, Bakker R, Mulder-Krieger T, van Veldhoven JP, de Vries H, Brussee J, and IJzerman AP (2009) A series of 2,4-disubstituted quinolines as a new class of allosteric enhancers of the adenosine $\mathrm{A}_{3}$ receptor. J Med Chem 52:926-931.

Heitman LH, Mulder-Krieger T, Spanjersberg RF, von Frijtag Drabbe Künzel JK Dalpiaz A, and IJzerman AP (2006) Allosteric modulation, thermodynamics and binding to wild-type and mutant (T277A) adenosine $\mathrm{A}_{1}$ receptors of LUF5831, a novel nonadenosine-like agonist. $\mathrm{Br} J$ Pharmacol 147:533-541.

Hider SL, Thomson W, Mack LF, Armstrong DJ, Shadforth M, and Bruce IN (2008) Polymorphisms within the adenosine receptor $2 \mathrm{a}$ gene are associated with adverse events in RA patients treated with MTX. Rheumatology (Oxford) 47:1156-1159.

Hillion J, Canals M, Torvinen M, Casado V, Scott R, Terasmaa A, Hansson A Watson S, Olah ME, Mallol J, et al. (2002) Coaggregation, cointernalization, and codesensitization of adenosine $\mathrm{A}_{2 \mathrm{~A}}$ receptors and dopamine $\mathrm{D}_{2}$ receptors. J Biol Chem 277:18091-18097.

Hohoff C, Mullings EL, Heatherley SV, Freitag CM, Neumann LC, Domschke K, Krakowitzky P, Rothermundt M, Keck ME, Erhardt A, et al. (2010) Adenosine A receptor gene: evidence for association of risk variants with panic disorder and anxious personality. $J$ Psychiatr Res 44:930-937.

Holschbach MH, Olsson RA, Bier D, Wutz W, Sihver W, Schüller M, Palm B, and Coenen HH (2002) Synthesis and evaluation of no-carrier-added 8-cyclopentyl-3(3- $\left[{ }^{18} \mathrm{~F}\right]$ fluoropropyl)-1-propylxanthine ([$\left.\left.{ }^{18} \mathrm{~F}\right] \mathrm{CPFPX}\right)$ : a potent and selective $\mathrm{A}_{1}$ adenosine receptor antagonist for in vivo imaging. $J$ Med Chem 45:5150-5156.

Hua X, Chason KD, Fredholm BB, Deshpande DA, Penn RB, and Tilley SL (2008) Adenosine induces airway hyperresponsiveness through activation of A3 receptors on mast cells. J Allergy Clin Immunol 122:107-113.

Hua X, Erikson CJ, Chason KD, Rosebrock CN, Deshpande DA, Penn RB, and Tilley SL (2007a) Involvement of A1 adenosine receptors and neural pathways in adenosine-induced bronchoconstriction in mice. Am J Physiol Lung Cell Mol Physiol 293:L25-L32

Hua X, Kovarova M, Chason KD, Nguyen M, Koller BH, and Tilley SL (2007b)
Enhanced mast cell activation in mice deficient in the A2b adenosine receptor. $J$ Exp Med 204:117-128.

Huang QY, Wei C, Yu L, Coelho JE, Shen HY, Kalda A, Linden J, and Chen JF (2006) Adenosine $\mathrm{A}_{2 \mathrm{~A}}$ receptors in bone marrow-derived cells but not in forebrain neurons are important contributors to 3-nitropropionic acid-induced striatal damage as revealed by cell-type-selective inactivation. $J$ Neurosci 26:11371-11378.

Huang ZL, Qu WM, Eguchi N, Chen JF, Schwarzschild MA, Fredholm BB, Urade Y, and Hayaishi $\mathrm{O}$ (2005) Adenosine $\mathrm{A}_{2 \mathrm{~A}}$, but not $\mathrm{A}_{1}$, receptors mediate the arousa effect of caffeine. Nat Neurosci 8:858-859.

Hussey MJ, Clarke GD, Ledent C, Hourani SM, and Kitchen I (2007) Reduced response to the formalin test and lowered spinal NMDA glutamate receptor binding in adenosine A2A receptor knockout mice. Pain 129:287-294.

Ivanov AA, Barak D, and Jacobson KA (2009) Evaluation of homology modeling of G-protein-coupled receptors in light of the $\mathrm{A}_{2 \mathrm{~A}}$ adenosine receptor crystallographic structure. J Med Chem 52:3284-3292.

Jaakola VP, Griffith MT, Hanson MA, Cherezov V, Chien EY, Lane JR, IJzerman $\mathrm{AP}$, and Stevens RC (2008) The 2.6 angstrom crystal structure of a human $\mathrm{A}_{2 \mathrm{~A}}$ adenosine receptor bound to an antagonist. Science 322:1211-1217.

Jacobson KA (2009) Introduction to adenosine receptors as therapeutic targets. Handbook of Experimental Pharmacology 193:1-24.

Jacobson KA, Gallo-Rodriguez C, Melman N, Fischer B, Maillard M, van Bergen A van Galen PJ, and Karton Y (1993a) Structure-activity relationships of 8-styrylxanthines as $\mathrm{A}_{2}$-selective adenosine antagonists. J Med Chem 36:1333-1342.

Jacobson KA, Fischer B, and Ji XD (1995) A "cleavable trifunctional" approach to receptor affinity labeling: regeneration of binding to $\mathrm{A}_{1}$-adenosine receptors. Bioconjugate Chem 6:255-263.

Jacobson KA, IJzerman AP, and Linden J (1999) 1,3-Dialkylxanthine derivative having high potency as antagonists at human $\mathrm{A}_{2 \mathrm{~B}}$ adenosine receptors. Drug Dev Res 47:45-53.

Jacobson KA and Gao ZG (2006) Adenosine receptors as therapeutic targets. Nat Rev Drug Discov 5:247-264.

Jenner P, Mori A, Hauser R, Morelli M, Fredholm BB, and Chen JF (2009) Adenosine, adenosine $\mathrm{A}_{2 \mathrm{~A}}$ antagonists and Parkinson's disease. Parkinsonism Relat Disord 15:406-413.

Jin X, Shepherd RK, Duling BR, and Linden J (1997) Inosine binds to A3 adenosine receptors and stimulates mast cell degranulation. J Clin Invest 100:2849-2857.

Johansson B, Halldner L, Dunwiddie TV, Masino SA, Poelchen W, Giménez-Llort L, Escorihuela RM, Fernández-Teruel A, Wiesenfeld-Hallin Z, Xu XJ, et al. (2001) Hyperalgesia, anxiety, and decreased hypoxic neuroprotection in mice lacking the adenosine $\mathrm{A}_{1}$ receptor. Proc Natl Acad Sci USA 98:9407-9412.

Johansson SM, Lindgren E, Yang JN, Herling AW, and Fredholm BB (2008) Adenosine $\mathrm{A}_{1}$ receptors regulate lipolysis and lipogenesis in mouse adipose tissueinteractions with insulin. Eur J Pharmacol 597:92-101.

Johansson SM, Salehi A, Sandström ME, Westerblad H, Lundquist I, Carlsson PO Fredholm BB, and Katz A (2007a) A1 receptor deficiency causes increased insulin and glucagon secretion in mice. Biochem Pharmacol 74:1628-1635.

Johansson SM, Yang JN, Lindgren E, and Fredholm BB (2007b) Eliminating the antilipolytic adenosine A1 receptor does not lead to compensatory changes of PGE2 or nicotinic acid effects on lipolysis. Acta Physiologica 190:87-96.

Kalk P, Eggert B, Relle K, Godes M, Heiden S, Sharkovska Y, Fischer Y, Ziegler D Bielenberg GW, and Hocher B (2007) The adenosine A receptor antagonist SLV320 reduces myocardial fibrosis in rats with $5 / 6$ nephrectomy without affecting blood pressure. Br J Pharmacol 151:1025-1032.

Kamiya T, Saitoh O, Yoshioka K, and Nakata H (2003) Oligomerization of adenosine $\mathrm{A}_{2 \mathrm{~A}}$ and dopamine $\mathrm{D}_{2}$ receptors in living cells. Biochem Biophys Res Commun 306:544-549.

Kara FM, Chitu V, Sloane J, Axelrod M, Fredholm BB, Stanley ER, and Cronstein $\mathrm{BN}$ (2010a) Adenosine A1 receptors (A1R) regulate bone resorption adenosine $\mathrm{A}_{1} \mathrm{R}$ play a critical role in osteoclast formation and function. FASEB $J \mathbf{2 4}: 2325-2333$. Kara FM, Doty SB, Boskey A, Goldring S, Zaidi M, Fredholm BB, and Cronstein BN (2010b) Adenosine $A_{1}$ receptors regulate bone homeostasis: adenosine A1R blockade or deletion increase bone density and prevents ovariectomy-induced bone loss Arthritis Rheum 62:534-541.

Kase H, Aoyama S, Ichimura M, Ikeda K, Ishii A, Kanda T, Koga K, Koike N, Kurokawa M, Kuwana $\mathrm{Y}$, et al. (2003) The adenosine $\mathrm{A}_{2 \mathrm{~A}}$ receptor selective antagonist KW6002: research toward a novel nondopaminergic therapy for Parkinson's disease. Neurology 61 (Suppl 6):S97-S100.

Katritch V, Jaakola VP, Lane JR, Lin J, IJzerman AP, Yeager M, Kufareva I, Stevens RC, and Abagyan R (2010) Structure-based discovery of novel chemotypes for adenosine $\mathrm{A}_{2 \mathrm{~A}}$ receptor antagonists. J Med Chem 53:1799-1809.

Kecskés M, Kumar TS, Yoo L, Gao ZG, and Jacobson KA (2010) Novel Alexa Fluor-488 labeled antagonist of the $\mathrm{A}_{2 \mathrm{~A}}$ adenosine receptor: application to a fluorescence polarization-based receptor binding assay. Biochem Pharmacol 80:506511.

Kiesman WF, Zhao J, Conlon PR, Petter RC, Jin X, Smits G, Lutterodt F, Sullivan GW, and Linden $J$ (2006a) Norbornyllactone-substituted xanthines as adenosine $\mathrm{A}_{1}$ receptor antagonists. Bioorg Med Chem 14:3654-3661.

Kiesman WF, Zhao J, Conlon PR, Dowling JE, Petter RC, Lutterodt F, Jin X, Smit G, Fure M, Jayaraj A, et al. (2006b) Potent and orally bioavailable 8-bicyclo[2.2.2] octylxanthines as adenosine $\mathrm{A}_{1}$ receptor antagonists. J Med Chem 49:7119-7131.

Kim J, Jiang Q, Glashofer M, Yehle S, Wess J, and Jacobson KA (1996) Glutamate residues in the second extracellular loop of the human $\mathrm{A}_{2 \mathrm{a}}$ adenosine receptors are required for ligand recognition. Mol Pharmacol, 49:683-691.

Kim SA, Marshall MA, Melman N, Kim HS, Müller CE, Linden J, and Jacobson KA (2002) Structure-activity relationships at human and rat $\mathrm{A}_{2 \mathrm{~B}}$ adenosine receptors of xanthine derivatives substituted at the 1-, 3-, 7-, and 8-positions. $J$ Med Chem 45:2131-2138

Kim SH, Kim YK, Park HW, Kim SH, Kim SH, Ye YM, Min KU, and Park HS (2009a) Adenosine deaminase and adenosine receptor polymorphisms in aspirin-intoleran asthma. Respir Med 103:356-363. 
Kim Y, de Castro S, Gao ZG, IJzerman AP, and Jacobson KA (2009b) Novel 2- and 4-substituted $1 \mathrm{H}$-imidazo[4,5-c] quinolin-4-amine derivatives as allosteric modulators of the $\mathrm{A}_{3}$ adenosine receptor. J Med Chem 52:2098-2108.

Kim YC, Ji X, Melman N, Linden J, and Jacobson KA (2000) Anilide derivatives of an 8-phenylxanthine carboxylic congener are highly potent and selective antagonists at human $\mathrm{A}_{2 \mathrm{~B}}$ adenosine receptors. J Med Chem 43:1165-1172.

King AE, Ackley MA, Cass CE, Young JD, and Baldwin SA (2006) Nucleoside transporters: from scavengers to novel therapeutic targets. Trends Pharmacol Sci 27:416-425

Klotz KN, Vogt H, and Tawfik-Schlieper H (1991) Comparison of $\mathrm{A}_{1}$ adenosine receptors in brain from different species by radioligand binding and photoaffinity labelling. Naunyn Schmiedebergs Arch Pharmacol 343:196-201.

Klotz KN, Hessling J, Hegler J, Owman C, Kull B, Fredholm BB, and Lohse MJ (1998) Comparative pharmacology of human adenosine receptor subtypescharacterization of stably transfected receptors in CHO cells. Naunyn Schmiedebergs Arch Pharmacol 357:1-9.

Klotz KN, Falgner N, Kachler S, Lambertucci C, Vittori S, Volpini R, and Cristalli G (2007) $\left[{ }^{3} \mathrm{H}\right]$ HEMADO - a novel tritiated agonist selective for the human adenosine $\mathrm{A}_{3}$ receptor. Eur J Pharmacol 556:14-18.

Kochanek PM, Vagni VA, Janesko KL, Washington CB, Crumrine PK, Garman RH, Jenkins LW, Clark RS, Homanics GE, Dixon CE, et al. (2006) Adenosine A receptor knockout mice develop lethal status epilepticus after experimental traumatic brain injury. J Cereb Blood Flow Metab 26:565-575.

Koszalka P, Ozüyaman B, Huo Y, Zernecke A, Flögel U, Braun N, Buchheiser A Decking UK, Smith ML, Sévigny J, et al. (2004) Targeted disruption of cd73/ecto5 '-nucleotidase alters thromboregulation and augments vascular inflammatory response. Circ Res 95:814-821.

Kourounakis AP, van de Klein PA, and IJzerman AP (2000) Elucidation of structureactivity relationships of 2-amino-3-benzoylthiophenes: study of their allosteric enhancing vs. antagonistic activity on adenosine $\mathrm{A}_{1}$ receptors. Drug Dev Res 49:227-237.

Kourounakis A, Visser C, de Groote M, and IJzerman AP (2001) Differential effects of the allosteric enhancer (2-amino-4,5-dimethyltrienyl)[3-(trifluoromethyl) phenyl]methanone (PD 81,723) on agonist and antagonist binding and function at the human wild-type and a mutant (T277A) adenosine $\mathrm{A}_{1}$ receptor. Biochem Pharmacol 61:137-144

Kuno A, Critz SD, Cui L, Solodushko V, Yang XM, Krahn T, Albrecht B, Philipp S, Cohen MV, and Downey JM (2007) Protein kinase C protects preconditioned rabbit hearts by increasing sensitivity of adenosine $\mathrm{A}_{2 \mathrm{~b}}$-dependent signalling during early reperfusion. J Mol Cell Cardiol 43:262-271.

Lane JR, Beukers MW, Mulder-Krieger T, and IJzerman AP (2010) The endocannabinoid 2-arachidonylglycerol is a negative allosteric modulator of the human $\mathrm{A}_{3}$ adenosine receptor. Biochem Pharmacol 79:48-56.

Lankford AR, Yang JN, Rose'Meyer R, French BA, Matherne GP, Fredholm BB, and Yang Z (2006) Effect of modulating cardiac $\mathrm{A}_{1}$ adenosine receptor expression on protection with ischemic preconditioning. Am J Physiol Heart Circ Physiol 290: H1469-H1473.

Lappas CM, Rieger JM, and Linden J (2005) A2A adenosine receptor induction inhibits IFN-gamma production in murine CD4+ T cells. $J$ Immunol 174:10731080 .

Lazarowski ER, Boucher RC, and Harden TK (2000) Constitutive release of ATP and evidence for major contribution of ecto-nucleotide pyrophosphatase and nucleoside diphosphokinase to extracellular nucleotide concentrations. J Biol Chem 275: 31061-31068.

Lazarowski ER, Boucher RC, and Harden TK (2003) Mechanisms of release of nucleotides and integration of their action as P2X- and P2Y-receptor activating molecules. Mol Pharmacol 64:785-795.

Ledent C, Vaugeois JM, Schiffmann SN, Pedrazzini T, El Yacoubi M, Vanderhaeghen JJ, Costentin J, Heath JK, Vassart G, and Parmentier M (1997) Aggressiveness, hypoalgesia and high blood pressure in mice lacking the adenosine $\mathrm{A}_{2 \mathrm{~A}}$ receptor. Nature 388:674-678.

LeWitt PA, Guttman M, Tetrud JW, Tuite PJ, Mori A, Chaikin P, Sussman NM; 6002-US-005 Study Group. Adenosine $\mathrm{A}_{2 \mathrm{~A}}$ receptor antagonist istradefylline (KW6002 ) reduces "off" time in Parkinson's disease: a double-blind, randomized, multicenter clinical trial (6002-US-005). Ann Neurol. 2008 Mar;63:295-302.

Liang BT, Urso R, Sambraski E, and Jacobson KA (2010) Adenosine $\mathrm{A}_{3}$ receptors in muscle protection, in $A_{3}$ Adenosine Receptors from Cell Biology to Pharmacology (Borea P ed) pp 257-280, Springer, Berlin.

Li X, Conklin D, Pan HL, and Eisenach JC (2003) Allosteric adenosine receptor modulation reduces hypersensitivity following peripheral inflammation by a central mechanism. J Pharmacol Exp Ther 305:950-955

Li T, Quan Lan J, Fredholm BB, Simon RP, and Boison D (2007) Adenosine dysfunction in astrogliosis: cause for seizure generation? Neuron Glia Biol 3:353-366.

Libert F, Schiffmann SN, Lefort A, Parmentier M, Gérard C, Dumont JE, Vanderhaeghen JJ, and Vassart G (1991) The orphan receptor cDNA RDC7 encodes an A1 adenosine receptor. EMBO J 10:1677-1682.

Lukashev DE, Smith PT, Caldwell CC, Ohta A, Apasov SG, and Sitkovsky MV (2003) Analysis of A2a receptor-deficient mice reveals no significant compensatory increases in the expression of $\mathrm{A} 2 \mathrm{~b}, \mathrm{~A} 1$, and $\mathrm{A} 3$ adenosine receptors in lymphoid organs. Biochem Pharmacol 65:2081-2090.

MacDonald PE, Braun M, Galvanovskis J, and Rorsman P (2006) Release of small transmitters through kiss-and-run fusion pores in rat pancreatic beta cells. Cell Metab 4:283-290.

Maenhaut C, Van Sande J, Libert F, Abramowicz M, Parmentier M, Vanderhaegen JJ, Dumont JE, Vassart G, and Schiffmann S (1990) RDC8 codes for an adenosine A2 receptor with physiological constitutive activity. Biochem Biophys Res Commun 173:1169-1178.

Magnani F, Shibata Y, Serrano-Vega MJ, and Tate CG (2008) Co-evolving stability and conformational homogeneity of the human adenosine $\mathrm{A}_{2 \mathrm{a}}$ receptor. Proc Natl Acad Sci USA 105:10744-10749.

Masino SA, Diao L, Illes P, Zahniser NR, Larson GA, Johansson B, Fredholm BB, and Dunwiddie TV (2002) Modulation of hippocampal glutamatergic transmission by ATP is dependent on adenosine A(1) receptors. J Pharmacol Exp Ther 303:356 363.

May LT, Sexton PM, and Christopoulos A (2005) Effects of urea pretreatment on the binding properties of adenosine A1 receptors. Br J Pharmacol 146:1119-1129.

Melman A, Gao ZG, Kumar D, Wan TC, Gizewski E, Auchampach JA, and Jacobson KA (2008) Design of (N)-methanocarbaadenosine 5'-uronamides as speciesindependent $\mathrm{A}_{3}$ receptor-selective agonists. Bioorg Med Chem Lett 18:2813-2819.

Michino M, Abola E, GPCR Dock 2008 participants, Brooks CL 3rd, Dixon JS, Moult J, and Stevens RC (2009) Community-wide assessment of GPCR structure modelling and ligand docking: GPCR Dock 2008. Nat Rev Drug Discov 8:455-463.

Minetti P, Tinti MO, Carminati P, Castorina M, Di Cesare MA, Di Serio S, Gallo G, Ghirardi O, Giorgi F, Giorgi L, et al. (2005) 2-n-Butyl-9-methyl-8-[1,2,3]triazol-2 yl-9H-purin-6-ylamine and analogues as $\mathrm{A}_{2 \mathrm{~A}}$ adenosine receptor antagonists. Design, synthesis, and pharmacological characterization. J Med Chem 48:68876896.

Mobarec JC, Sanchez R, and Filizola M (2009) Modern homology modeling of G-protein coupled receptors: which structural template to use? J Med Chem 52:52075216.

Montesinos MC, Desai A, Chen JF, Yee H, Schwarzschild MA, Fink JS, and Cronstein BN (2002) Adenosine promotes wound healing and mediates angiogenesis in response to tissue injury via occupancy of $\mathrm{A}(2 \mathrm{~A})$ receptors. Am J Pathol 160:2009 2018 .

Morrison RR, Talukder MA, Ledent C, and Mustafa SJ (2002) Cardiac effects of adenosine in $\mathrm{A}(2 \mathrm{~A})$ receptor knockout hearts: uncovering $\mathrm{A}(2 \mathrm{~B})$ receptors. Am $J$ Physiol Heart Circ Physiol 282:H437-H444.

Müller CE (2000a) $\mathrm{A}_{2 \mathrm{~A}}$ Adenosine receptor antagonists-future drugs for Parkinson's disease? Drugs Future 25:1043-1052.

Müller CE (2000b) Adenosine receptor ligands-recent developments part I. Agonists. Curr Med Chem 7:1269-1288.

Müller CE, Diekmann M, Thorand M, and Ozola V (2002b) $\left[{ }^{3} \mathrm{H}\right]$ 8-Ethyl-4-methyl-2 phenyl-( $8 R)$-4,5,7,8-tetrahydro- $1 H$-imidazo[2,1-i $]$ purin-5-one $\left(\left[{ }^{3} \mathrm{H}\right] \mathrm{PSB}-11\right)$, a novel high-affinity antagonist radioligand for human $\mathrm{A}_{3}$ adenosine receptors. Bioorg Med Chem Lett 12:501-503.

Müller CE and Ferré S (2007) Blocking striatal adenosine $\mathrm{A}_{2 \mathrm{~A}}$ receptors: a new strategy for basal ganglia disorders. Recent Pat CNS Drug Discov 2:1-21.

Müller CE and Jacobson KA (2011) Recent developments in adenosine receptor ligands and their potential as novel drugs. Biochim Biophys Acta doi: 10.1016/ j.bbamem.2010.12.017.

Müller CE, Maurinsh J, and Sauer R (2000) Binding of $\left[{ }^{3} \mathrm{H}\right] \mathrm{MSX}-2$ (3-(3 hydroxypropyl)-7-methyl-8-( $m$-methoxystyryl)-1-propargylxanthine) to rat striatal membranes-a new, selective antagonist radioligand for $\mathrm{A}_{2 \mathrm{~A}}$ adenosine receptors. Eur J Pharm Sci 10:259-265.

Müller CE, Shi D, Manning M Jr, and Daly JW (1993b) Synthesis of paraxanthine analogs (1,7-disubstituted xanthines) and other xanthines unsubstituted at the 3-position: structure-activity relationships at adenosine receptors. J Med Chem 36:3341-3349.

Müller CE and Stein B (1996) Adenosine receptor antagonists: structures and potential therapeutic applications. Curr Pharm Des 2:501-530.

Müller CE, Thorand M, Qurishi R, Diekmann M, Jacobson KA, Padgett WL, and Daly JW (2002a) Imidazo[2,1-i]purin-5-ones and related tricyclic water-soluble purine derivatives: potent $\mathrm{A}_{2 \mathrm{~A}^{-}}$and $\mathrm{A}_{3}$-adenosine receptor antagonists. $J \mathrm{Med}$ Chem 45:3440-3450

Murphree LJ, Sullivan GW, Marshall MA, and Linden J (2005) Lipopolysaccharide rapidly modifies adenosine receptor transcripts in murine and human macrophages: role of NF-kappaB in $\mathrm{A}_{2 \mathrm{~A}}$ adenosine receptor induction. Biochem $J$ 391: $575-580$.

Nakata H, Yoshioka K, Kamiya T, Tsuga H, and Oyanagi K (2005) Functions of heteromeric association between adenosine and P2Y receptors. J Mol Neurosci 26:233-238.

Narlawar R, Lane JR, Doddareddy M, Lin J, Brussee J, and IJzerman AP (2010) Hybrid ortho/allosteric ligands for the adenosine $\mathrm{A}_{1}$ receptor. J Med Chem 53: 3028-3037.

Navarro G, Aymerich MS, Marcellino D, Cortés A, Casadó V, Mallol J, Canela EI, Agnati L, Woods AS, Fuxe K, et al. (2009) Interactions between calmodulin, adenosine $\mathrm{A}_{2 \mathrm{~A}}$, and dopamine $\mathrm{D}_{2}$ receptors. J Biol Chem 284:28058-28068.

Navarro G, Carriba P, Gandía J, Ciruela F, Casadó V, Cortés A, Mallol J, Canela EI Lluis C, and Franco R (2008) Detection of heteromers formed by cannabinoid $\mathrm{CB}_{1}$, dopamine $\mathrm{D}_{2}$, and adenosine $\mathrm{A}_{2 \mathrm{~A}}$ G-protein-coupled receptors by combining bimolecular fluorescence complementation and bioluminescence energy transfer. ScientificWorldJournal 8:1088-1097.

Newby AC (1984) Adenosine and the concept of "retaliatory metabolites". Trends Biochem 9:42-44.

Nikolakopoulos G, Figler H, Linden J, and Scammells PJ (2006) 2-Aminothiophene3 -carboxylates and carboxamides as adenosine $\mathrm{A}_{1}$ receptor allosteric enhancers. Bioorg Med Chem 14:2358-2365.

Ochaion A, Bar-Yehuda S, Cohen S, Barer F, Patoka R, Amital H, Reitblat T, Reitblat A, Ophir J, Konfino I, et al. (2009) The anti-inflammatory target A adenosine receptor is over-expressed in rheumatoid arthritis, psoriasis and Crohn's disease. Cell Immunol 258:115-122.

Ohta A, Lukashev D, Jackson EK, Fredholm BB, and Sitkovsky M (2007) 1,3,7Trimethylxanthine (caffeine) may exacerbate acute inflammatory liver injury by weakening the physiological immunosuppressive mechanism. J Immunol 179: $7431-7438$

Ohta A and Sitkovsky M (2001) Role of G-protein-coupled adenosine receptors in downregulation of inflammation and protection from tissue damage. Nature 414: $916-920$

Oishi Y, Huang ZL, Fredholm BB, Urade Y, and Hayaishi O (2008) Adenosine in the tuberomammillary nucleus suppresses the histaminergic system via $\mathrm{A}_{1}$ receptor and promotes non-rapid eye movement sleep. Proc Natl Acad Sci USA 105:19992 19997. 
Okada SF, Nicholas RA, Kreda SM, Lazarowski ER, and Boucher RC (2006) Physiological regulation of ATP release at the apical surface of human airway epithelia. J Biol Chem 281:22992-23002.

Ozola V, Thorand M, Diekmann M, Qurishi R, Schumacher B, Jacobson KA, and Müller CE (2003) 2-Phenylimidazo[2,1-i]purin-5-ones: structure-activity relationships and characterization of potent and selective inverse agonists at human $\mathrm{A}_{3}$ adenosine receptors. Bioorg Med Chem 11:347-356.

Parkinson FE and Fredholm BB (1992) Magnesium-dependent enhancement of endogenous agonist binding to A1 adenosine receptors: a complicating factor in quantitative autoradiography. J Neurochem 58:941-950.

Pfister JR, Belardinelli L, Lee G, Lum RT, Milner P, Stanley WC, Linden J, Baker SP, and Schreiner G (1997) Synthesis and biological evaluation of the enantiomers of the potent and selective $A_{1}$-adenosine antagonist 1,3-dipropyl-8-[2-(5,6epoxynorbornyl)]xanthine. J Med Chem 40:1773-1778.

Picher M, Burch LH, Hirsh AJ, Spychala J, and Boucher RC (2003) Ecto 5'nucleotidase and nonspecific alkaline phosphatase. Two AMP-hydrolyzing ectoenzymes with distinct roles in human airways. J Biol Chem 278:13468-13479.

Pin JP, Neubig R, Bouvier M, Devi L, Filizola M, Javitch JA, Lohse MJ, Milligan G, Palczewski K, Parmentier M, et al. (2007) International Union of Basic and Clinical Pharmacology. LXVII. Recommendations for the recognition and nomenclature of G protein-coupled receptor heteromultimers. Pharmacol Rev 59:5-13.

Pinna A (2009) Novel investigational adenosine $A_{2 A}$ receptor antagonists for Parkinson's disease. Expert opinion on investigational drugs 18:1619-1631.

Popescu FD and Popescu F (2007) A review of antisense therapeutic interventions for molecular biological targets in asthma. Biologics 1:271-283.

Pretorius J, Malan SF, Castagnoli N Jr., Bergh JJ, and Petzer JP (2008) Dual inhibition of monoamine oxidase $\mathrm{B}$ and antagonism of the adenosine $\mathrm{A}_{2 \mathrm{~A}}$ receptor by $(E, E)-8$-(4-phenylbutadien-1-yl)caffeine analogues. Bioorg Med Chem 16:86768684.

Rétey JV, Adam M, Honegger E, Khatami R, Luhmann UF, Jung HH, Berger W, and Landolt HP (2005) A functional genetic variation of adenosine deaminase affects the duration and intensity of deep sleep in humans. Proc Natl Acad Sci USA 102:15676-15681.

Rétey JV, Adam M, Khatami R, Luhmann UF, Jung HH, Berger W, and Landolt HP (2007) A genetic variation in the adenosine A2A receptor gene (ADORA2A) contributes to individual sensitivity to caffeine effects on sleep. Clin Pharmacol Ther 81:692-698.

Reutershan J, Cagnina RE, Chang D, Linden J, and Ley K (2007) Therapeutic anti-inflammatory effects of myeloid cell adenosine receptor A2a stimulation in lipopolysaccharide-induced lung injury. J Immunol 179:1254-1263.

Riksen NP, Zhou Z, Oyen WJ, Jaspers R, Ramakers BP, Brouwer RM, Boerman OC, Steinmetz N, Smits P, and Rongen GA (2006) Caffeine prevents protection in two human models of ischemic preconditioning. J Am Coll Cardiol 48:700-707.

Rivkees SA and Reppert SM (1992) RFL9 encodes an A2b-adenosine receptor. Mol Endocrinol 6:1598-1604.

Robson SC, Wu Y, Sun X, Knosalla C, Dwyer K, and Enjyoji K (2005) Ectonucleotidases of CD39 family modulate vascular inflammation and thrombosis in transplantation. Semin Thromb Hemost 31:217-233.

Romano C, Yang WL, and O'Malley KL (1996) Metabotropic glutamate receptor 5 is a disulfide-linked dimer. J Biol Chem 271:28612-28616.

Romagnoli R, Baraldi PG, Carrion MD, Cara CL, Cruz-Lopez O, Iaconinoto MA, Preti D, Shryock JC, Moorman AR, Vincenzi F, et al. (2008) Synthesis and biological evaluation of 2-amino-3-(4-chlorobenzoyl)-4-[ $N$-(substituted)piperazin-1yl]thiophenes as potent allosteric enhancers of the $\mathrm{A}_{1}$ adenosine receptor. $J \mathrm{Med}$ Chem 51:5875-5879.

Rork TH, Wallace KL, Kennedy DP, Marshall MA, Lankford AR, and Linden J (2008) Adenosine $\mathrm{A}_{2 \mathrm{~A}}$ receptor activation reduces infarct size in the isolated, perfused mouse heart by inhibiting resident cardiac mast cell degranulation. Am J Physiol Heart Circ Physiol 295:H1825-H1833.

Rosenbaum DM, Rasmussen SG, and Kobilka BK (2009) The structure and function of G-protein-coupled receptors. Nature 459:356-363.

Rovira X, Pin JP, and Giraldo J (2010) The asymmetric/symmetric activation of GPCR dimers as a possible mechanistic rationale for multiple signalling pathways. Trends Pharmacol Sci 31:15-21.

Ryzhov S, Zaynagetdinov R, Goldstein AE, Novitskiy SV, Blackburn MR, Biaggioni $\mathrm{I}$, and Feoktistov I (2008) Effect of $\mathrm{A}_{2 \mathrm{~B}}$ adenosine receptor gene ablation on adenosine-dependent regulation of proinflammatory cytokines. J Pharmacol Exp Ther 324:694-700.

Saadjian AY, Gerolami V, Giorgi R, Mercier L, Berge-Lefranc JL, Paganelli F, Ibrahim Z, By Y, Guéant JL, Lévy S, et al. (2009) Head-up tilt induced syncope and adenosine $\mathrm{A}_{2 \mathrm{~A}}$ receptor gene polymorphism. Eur Heart $J$ 30:1510-1515.

Sajjadi FG, Takabayashi K, Foster AC, Domingo RC, and Firestein GS (1996) Inhibition of TNF-alpha expression by adenosine: role of $\mathrm{A}_{3}$ adenosine receptors. J Immunol 156:3435-3442.

Saki M, Tsumuki H, Nonaka H, Shimada J, and Ichimura M (2002) KF26777 (2-(4-bromophenyl)-7,8-dihydro-4-propyl- $1 H$-imidazo[2,1-i]purin-5(4H)-one dihydrochloride), a new potent and selective adenosine $\mathrm{A}_{3}$ receptor antagonist. Eur I Pharmacol 444:133-141.

Salvatore CA, Jacobson MA, Taylor HE, Linden J, and Johnson RG (1993) Molecular cloning and characterization of the human $\mathrm{A}_{3}$ adenosine receptor. Proc Natl Acad Sci USA 90:10365-10369.

Salvatore CA, Tilley SL, Latour AM, Fletcher DS, Koller BH, and Jacobson MA (2000) Disruption of the $\mathrm{A}(3)$ adenosine receptor gene in mice and its effect on stimulated inflammatory cells. J Biol Chem 275:4429-4434.

Sauer R, Maurinsh J, Reith U, Fülle F, Klotz KN, and Müller CE (2000) Watersoluble phosphate prodrugs of 1-propargyl-8-styrylxanthine derivatives, $\mathrm{A}_{2 \mathrm{~A}^{-}}$ selective adenosine receptor antagonists. J Med Chem 43:440-448.

Saura C, Ciruela F, Casadó V, Canela EI, Mallol J, Lluis C, and Franco R (1996) Adenosine deaminase interacts with $\mathrm{A}_{1}$ adenosine receptors in pig brain cortical membranes. J Neurochem 66:1675-1682.

Scammell TE, Arrigoni E, Thompson MA, Ronan PJ, Saper CB, and Greene RW
(2003) Focal deletion of the adenosine $\mathrm{A}_{1}$ receptor in adult mice using an adenoassociated viral vector. $J$ Neurosci 23:5762-5770.

Schulte $\mathrm{G}$ and Fredholm BB (2000) Human adenosine $\mathrm{A}_{1}, \mathrm{~A}_{2 \mathrm{~A}}, \mathrm{~A}_{2 \mathrm{~B}}$, and $\mathrm{A}_{3}$ receptors expressed in Chinese hamster ovary cells all mediate the phosphorylation of extracellular-regulated kinase 1/2. Mol Pharmacol 58:477-482

Schulte G, Sommerschild H, Yang J, Tokuno S, Goiny M, Lövdahl C, Johansson B, Fredholm BB, and Valen G (2004) Adenosine A receptors are necessary for protection of the murine heart by remote, delayed adaptation to ischaemia. Acto Physiol Scand 182:133-143.

Schwartz TW and Holst B (2006) Ago-allosteric modulation and other types of allostery in dimeric 7TM receptors. J Recept Signal Transduct Res 26:107-128.

Shen HY, Coelho JE, Ohtsuka N, Canas PM, Day YJ, Huang QY, Rebola N, Yu L, Boison D, Cunha RA, et al. (2008) A critical role of the adenosine A2A receptor in extrastriatal neurons in modulating psychomotor activity as revealed by opposite phenotypes of striatum and forebrain A2A receptor knock-outs. J Neurosci 28: 2970-2975.

Shimada J, Koike N, Nonaka H, Shiozaki S, Yanagawa K, Kanda T, Kobayashi H Ichimura M, Nakamura J, Kase H, et al. (1997) Adenosine $\mathrm{A}_{2 \mathrm{~A}}$ antagonists with potent anti-cataleptic activity. Bioorg Med Chem Lett 7:2349-2352.

Solinas M, Ferré S, Antoniou K, Quarta D, Justinova Z, Hockemeyer J, Pappas LA Segal PN, Wertheim C, Müller CE, and Goldberg SR. Pappas LA, Segal PN, Wertheim C, Müller CE, and Goldberg SR (2005) Involvement of adenosine A receptors in the discriminative-stimulus effects of caffeine in rats. Psychopharmacology 179:576-586

Spray DC, Ye ZC, and Ransom BR (2006) Functional connexin "hemichannels": critical appraisal. Glia 54:758-773.

Stacy M, Silver D, Mendis T, Sutton J, Mori A, Chaikin P, and Sussman NM (2008) A 12-week, placebo-controlled study (6002-US-006) of istradefylline in Parkinson disease [published erratum appears in Neurology 71:953, 2008]. Neurology 70: $2233-2240$

Stenberg D, Litonius E, Halldner L, Johansson B, Fredholm BB, and PorkkaHeiskanen T (2003) Sleep and its homeostatic regulation in mice lacking the adenosine A1 receptor. J Sleep Res 12:283-290.

Sun D, Samuelson LC, Yang T, Huang Y, Paliege A, Saunders T, Briggs J, and Schnermann J (2001) Mediation of tubuloglomerular feedback by adenosine: evidence from mice lacking adenosine 1 receptors. Proc Natl Acad Sci USA 98:99839988

Suzuki T, Namba K, Tsuga H, and Nakata H (2006) Regulation of pharmacology by hetero-oligomerization between $\mathrm{A}_{1}$ adenosine receptor and $\mathrm{P}_{2} \mathrm{Y}_{2}$ receptor. Biochem Biophys Res Commun 351:559-565.

Suzuki T, Namba K, Yamagishi R, Kaneko H, Haga T, and Nakata H (2009) A highly conserved tryptophan residue in the fourth transmembrane domain of the $\mathrm{A}$ adenosine receptor is essential for ligand binding but not receptor homodimerization. J Neurochem 110:1352-1362.

Svenningsson P, Le Moine C, Fisone G, and Fredholm BB (1999) Distribution, biochemistry and function of striatal adenosine $\mathrm{A}_{2 \mathrm{~A}}$ receptors. Prog Neurobiol 59:355-396.

Tang Z, Diamond MA, Chen JM, Holly TA, Bonow RO, Dasgupta A, Hyslop T, Purzycki A, Wagner J, McNamara DM, et al. (2007) Polymorphisms in adenosine receptor genes are associated with infarct size in patients with ischemic cardiomyopathy. Clin Pharmacol Ther 82:435-440.

Tawfik HE, Schnermann J, Oldenburg PJ, and Mustafa SJ (2005) Role of A1 adenosine receptors in regulation of vascular tone. Am J Physiol Heart Circ Physiol 288:H1411-H1416.

Teng B, Ledent C, and Mustafa SJ (2008) Up-regulation of $\mathrm{A}_{2 \mathrm{~B}}$ adenosine receptor in $\mathrm{A}_{2 \mathrm{~A}}$ adenosine receptor knockout mouse coronary artery. J Mol Cell Cardiol 44:905-914.

Thompson LF, Eltzschig HK, Ibla JC, Van De Wiele CJ, Resta R, Morote-Garcia JC and Colgan SP (2004) Crucial role for ecto-5'-nucleotidase (CD73) in vascular leakage during hypoxia. J Exp Med 200:1395-1405.

Tilley SL, Wagoner VA, Salvatore CA, Jacobson MA, and Koller BH (2000) Adenosine and inosine increase cutaneous vasopermeability by activating $\mathrm{A}_{3}$ receptors on mast cells. J Clin Invest 105:361-367.

Torvinen M, Ginés S, Hillion J, Latini S, Canals M, Ciruela F, Bordoni F, Staines W, Pedata F, Agnati LF, et al. (2002) Interactions among adenosine deaminase, adenosine $A_{1}$ receptors and dopamine $D_{1}$ receptors in stably cotransfected fibroblast cells and neurons. Neuroscience 113:709-719

Torvinen M, Marcellino D, Canals M, Agnati LF, Lluis C, Franco R, and Fuxe K (2005) Adenosine $A_{2}$ receptor and dopamine $D_{3}$ receptor interactions: evidence of functional $\mathrm{A}_{2 \mathrm{~A}} / \mathrm{D}_{3}$ heteromeric complexes. Mol Pharmacol 67:400-407.

Tracey WR, Magee WP, Oleynek JJ, Hill RJ, Smith AH, Flynn DM, and Knight DR (2003) Novel $\mathrm{N}^{6}$-substituted adenosine $5^{\prime}$-N-methyluronamides with high selectivity for human adenosine $\mathrm{A}_{3}$ receptors reduce ischemic myocardial injury. Am $J$ Physiol Heart Circ Physiol 285:H2780-H2787.

Ukena D, Jacobson KA, Padgett WL, Ayala C, Shamim MT, Kirk KL, Olsson RO, and Daly JW (1986b) Species differences in structure-activity relationships of adenosine agonists and xanthine antagonists at brain $\mathrm{A}_{1}$ adenosine receptors. FEBS Lett 209:122-128.

Valant C, Aurelio L, Urmaliya VB, White P, Scammells PJ, Sexton PM, and Christopoulos A (2010) Delineating the mode of action of adenosine $\mathrm{A}_{1}$ receptor allosteric modulators. Mol Pharmacol 78:444-455.

van der Klein PA, Kourounakis AP, and IJzerman AP (1999) Allosteric modulation of the adenosine $\mathrm{A}_{1}$ receptor: synthesis and biological evaluation of novel 2-amino3-benzoylthiophenes as allosteric enhancers of agonist binding. J Med Chem 42:3629-3635

van Galen PJ, Nissen P, van Wijngaarden I, IJzerman AP, and Soudijn W (1991) $1 \mathrm{H}$-imidazo[4,5-c]quinolin-4-amines: novel non-xanthine adenosine antagonists. $J$ Med Chem 34:1202-1206.

van Galen PJ, van Bergen AH, Gallo-Rodriguez C, Melman N, Olah ME, IJzerman AP, Stiles GL, and Jacobson KA (1994) A binding site model and structure-activity relationships for the rat $\mathrm{A}_{3}$ adenosine receptor. Mol Pharmacol 45:1101-1111. 
van Muijlwijk-Koezen JE, Timmerman H, Link R, van der Goot H, and IJzerman AP (1998) A novel class of adenosine $\mathrm{A}_{3}$ receptor ligands. 1. 3-(2-Pyridinyl)isoquinoline derivatives. $J$ Med Chem 41:3987-3993.

van Muijlwijk-Koezen JE, Timmerman H, van der Goot H, Menge WM, Frijtag Von Drabbe Künzel J, de Groote M, and IJzerman AP (2000) Isoquinoline and quinazoline urea analogues as antagonists for the human adenosine $\mathrm{A}_{3}$ receptors. $J \mathrm{Med}$ Chem 43:2227-2238.

Varani K, Maniero S, Vincenzi F, Targa M, Stefanelli A, Maniscalco P, Martini F, Tognon M, and Borea PA (2011) $\mathrm{A}_{3}$ receptors are overexpressed in pleura from mesothelioma patients and reduce cell growth via Akt/NF-kB pathway. Am J Resp Crit Care Med doi:10.1164/rcem.201006-0980OC.

Varani K, Vincenzi F, Tosi A, Targa M, Masieri FF, Ongaro A, De Mattei M, Massari L, and Borea PA (2010) Expression and functional role of adenosine receptors in regulating inflammatory responses in human synoviocytes. $\mathrm{Br}$ J Pharmacol 160: $101-115$.

Vidal B, Nueda A, Esteve C, Domenech T, Benito S, Reinoso RF, Pont M, Calbet M López R, Cadavid MI, et al. (2007) Discovery and characterization of $4^{\prime}$-(2-furyl)N-pyridin-3-yl-4,5'-bipyridmidin-2' -amine (LAS38096), a potent, selective, and efficacious $\mathrm{A}_{2 \mathrm{~B}}$ adenosine receptor antagonist. J Med Chem 50:2732-2736.

Vidi PA, Chemel BR, Hu CD, and Watts VJ (2008a) Ligand-dependent oligomerization of dopamine $\mathrm{D}_{2}$ and adenosine $\mathrm{A}_{2 \mathrm{~A}}$ receptors in living neuronal cells. Mol Pharmacol 74:544-551.

Vidi PA, Chen J, Irudayaraj JM, and Watts VJ (2008b) Adenosine $\mathrm{A}_{2 \mathrm{~A}}$ receptors assemble into higher-order oligomers at the plasma membrane. FEBS Lett 582: 3985-3990.

Volpini R, Costanzi S, Lambertucci C, Taffi S, Vittori S, Klotz KN, and Cristalli G (2002) N6-alkyl-2-alkynyl derivatives of adenosine as potent and selective agonists at the human adenosine $\mathrm{A} 3$ receptor and a starting point for searching $\mathrm{A}_{2 \mathrm{~B}}$ ligands. $J$ Med Chem 45:3271-3279.

Volpini R, Buccioni M, Dal Ben D, Lambertucci C, Lammi C, Marucci G, Ramadori AT, Klotz KN, and Cristalli G (2009) Synthesis and biological evaluation of 2-alkynyl-N ${ }^{6}$-methyl-5'-N-methylcarboxamidoadenosine derivatives as potent and highly selective agonists for the human adenosine $\mathrm{A}_{3}$ receptor. $\mathrm{J}$ Med Chem 52:7897-7900.

Wan TC, Ge ZD, Tampo A, Mio Y, Bienengraeber MW, Tracey WR, Gross GJ, Kwok WM, and Auchampach JA (2008) The $\mathrm{A}_{3}$ adenosine receptor agonist CP-532,903 [N6-(2,5-dichlorobenzyl)-3'-aminoadenosine-5'-N-methylcarboxamide] protects against myocardial ischemia/reperfusion injury via the sarcolemmal ATPsensitive potassium channel. J Pharmacol Exp Ther 324:234-243.

Wang Y, Yang J, Arner A, Boels P, and Fredholm BB (2010) Adenosine A 1 receptors and vascular reactivity. Acta Physiol (Oxf) 199:211-220.

Wendler CC, Amatya S, McClaskey C, Ghatpande S, Fredholm BB, and Rivkees SA (2007) $A_{1}$ adenosine receptors play an essential role in protecting the embryo against hypoxia. Proc Natl Acad Sci USA 104:9697-9702.

Weyler S, Fülle F, Diekmann M, Schumacher B, Hinz S, Klotz KN, and Müller CE (2006) Improving potency, selectivity, and water-solubility of adenosine $\mathrm{A}_{1}$ receptor antagonists: xanthines modified at position 3 and related pyrimido[1,2,3$c d$ lpurinediones. ChemMedChem 1:891-902.

White JF, Grodnitzky J, Louis JM, Trinh LB, Shiloach J, Gutierrez J, Northup JK, and Grisshammer R.K. \& Grisshammer, R. (2007) Dimerization of the class A G protein-coupled neurotensin receptor NTS1 alters G protein interaction. Proc Natl Acad Sci USA 104:12199-12204.

Whorton MR, Bokoch MP, Rasmussen SG, Huang B, Zare RN, Kobilka B, and
Sunahara RK (2007) A monomeric G protein-coupled receptor isolated in a highdensity lipoprotein particle efficiently activates its G protein. Proc Natl Acad Sci USA 104:7682-7687.

Whorton MR, Jastrzebska B, Park PS, Fotiadis D, Engel A, Palczewski, K. \& Sunahara, R.K., (2008)Efficient coupling of transducin to monomeric rhodopsin in a phospholipid bilayer. J Biol Chem 283:4387-4394.

Wilson CN and Mustafa SJ (2009) Adenosine receptors in health and disease. Handb Exp Pharmacol 193:1-652.

Wu WP, Hao JX, Halldner-Henriksson L, Xu XJ, Jacobson MA, Wiesenfeld-Hallin Z, and Fredholm BB (2002) Decreased inflammatory pain due to reduced carrageenan-induced inflammation in mice lacking adenosine $\mathrm{A}_{3}$ receptors. Neuroscience 114:523-527.

Wu WP, Hao JX, Halldner L, Lövdahl C, DeLander GE, Wiesenfeld-Hallin Z, Fredholm BB, and Xu XJ (2005) Increased nociceptive response in mice lacking the adenosine $\mathrm{A}_{1}$ receptor. Pain 113:395-404.

Yaar R, Jones MR, Chen JF, and Ravid K (2005) Animal models for the study of adenosine receptor function. J Cell Physiol 202:9-20.

Yan L, Burbiel JC, Maass A, and Müller CE (2003) Adenosine receptor agonists: from basic medicinal chemistry to clinical development. Expert Opin Emerg Drugs 8:537-576.

Yang D, Koupenova M, McCrann DJ, Kopeikina KJ, Kagan HM, Schreiber BM, and Ravid $\mathrm{K}$ (2008) The $\mathrm{A}_{2 \mathrm{~b}}$ adenosine receptor protects against vascular injury. Proc Natl Acad Sci USA 105:792-796.

Yang D, Zhang Y, Nguyen HG, Koupenova M, Chauhan AK, Makitalo M, Jones MR, St Hilaire C, Seldin DC, Toselli P, et al. (2006) The $\mathrm{A}_{2 \mathrm{~B}}$ adenosine receptor protects against inflammation and excessive vascular adhesion. J Clin Invest 116:19131923.

Yang JN, Chen JF, and Fredholm BB (2009a) Physiological roles of $\mathrm{A}_{1}$ and $\mathrm{A}_{2 \mathrm{~A}}$ adenosine receptors in regulating heart rate, body temperature, and locomotion as revealed using knockout mice and caffeine. Am J Physiol Heart Circ Physiol 296:H1141-H1149.

Yang JN, Björklund O, Lindström-Törnqvist K, Lindgren E, Eriksson TM, Kahlström J, Chen JF, Schwarzschild MA, Tobler I, and Fredholm BB (2009b) Mice heterozygous for both $\mathrm{A}_{1}$ and $\mathrm{A}_{2 \mathrm{~A}}$ adenosine receptor genes show similarities to mice given long-term caffeine. J Appl Physiol 106:631-639.

Yang JN, Tiselius C, Daré E, Johansson B, Valen G, and Fredholm BB (2007) Sex differences in mouse heart rate and body temperature and in their regulation by adenosine A1 receptors. Acta Physiologica 190:63-75.

Yang Z, Day YJ, Toufektsian MC, Xu Y, Ramos SI, Marshall MA, French BA, and Linden J (2006) Myocardial infarct-sparing effect of adenosine $A_{2 A}$ receptor activation is due to its action on CD4+ T lymphocytes. Circulation 114:2056-2064.

Yoshioka K, Hosoda R, Kuroda Y, and Nakata H (2002) Hetero-oligomerization of adenosine $\mathrm{A}_{1}$ receptors with $\mathrm{P} 2 \mathrm{Y} 1$ receptors in rat brains. FEBS Lett 531:299-303.

Yoshioka K, Saitoh O, and Nakata H (2001) Heteromeric association creates a P2Y-like adenosine receptor. Proc Natl Acad Sci USA 98:7617-7622.

Zhang Q, Li Y, and Tsien RW (2009) The dynamic control of kiss-and-run and vesicular reuse probed with single nanoparticles. Science 323:1448-1453.

Zhang Z, Chen G, Zhou W, Song A, Xu T, Luo Q, Wang W, Gu XS, and Duan S (2007) Regulated ATP release from astrocytes through lysosome exocytosis. Nat Cell Biol 9:945-953.

Zhou QY, Li C, Olah ME, Johnson RA, Stiles GL, and Civelli O (1992) Molecular cloning and characterization of an adenosine receptor: the $\mathrm{A}_{3}$ adenosine receptor. Proc Natl Acad Sci USA 89:7432-7436. 